\title{
Geochemical signature and reservoir conditions of Early Jurassic calc- alkaline volcanic rocks from Lonco Trapial Formation, Central Patagonia
}

\author{
Claudia Zaffarana ${ }^{\mathrm{a}, \mathrm{b}, *}$, Gloria Gallastegui ${ }^{\mathrm{c}}$, Silvia Lagorio ${ }^{\mathrm{d}}$, Stella Poma ${ }^{\mathrm{b}, \mathrm{e}}$, Alicia Busteros ${ }^{\mathrm{d}}$, \\ Samanta Serra Varela ${ }^{\mathrm{a}, \mathrm{b}}$, Darío Orts ${ }^{\mathrm{a}, \mathrm{b}}$, Diego Silva Nieto ${ }^{\mathrm{d}}$, Raúl Giacosaa, ${ }^{\mathrm{a}, \mathrm{d}}$, \\ Víctor Ruiz González ${ }^{\mathrm{b}, \mathrm{e}}$, Carla Puigdomenech ${ }^{\mathrm{b}, \mathrm{e}}$, Bárbara Boltshauser ${ }^{\mathrm{a}, \mathrm{b}}$, Rubén Somoza \\ a Universidad Nacional de Río Negro, Av. Julio A. Roca 1242 General Roca (8332), Pcia, de Río Negro, Argentina \\ ${ }^{\mathrm{b}}$ Consejo Nacional de Investigaciones Científicas y Técnicas (CONICET), Argentina \\ ${ }^{\mathrm{c}}$ Instituto Geológico y Minero de España (IGME), Spain \\ d Servicio Geológico Minero Argentino (SEGEMAR), Argentina \\ e Departamento de Geología de la FCEyN de la Universidad de Buenos Aires, Argentina
}

\section{A R T I C L E I N F O}

\section{Keywords:}

Andesite

Jurassic

Mineral chemistry

Whole-rock geochemistry

Central patagonia

\begin{abstract}
A B S T R A C T
Central Patagonia is traversed by a belt of Early to Middle Jurassic calc-alkaline intermediate volcanic rocks interspersed with more felsic volcanic rocks which are associated with the widespread magmatism that took place during Gondwana break-up times. This work uses $\mathrm{K}-\mathrm{Ar}$ and $\mathrm{Ar}-\mathrm{Ar}$ dating and whole-rock and phenocryst (plagioclase, amphibole, clinopyroxene and titanomagnetite) compositional data to refine the age, geochemical signature and reservoir conditions of these volcanic rocks, which are known as Lonco Trapial Formation. The andesites, dacites and trachydacites which were the object of this study have either amphibole or clinopyroxene as the main mafic phenocryst (amphibole-bearing and clinopyroxene-bearing volcanic rocks, respectively), though amphibole is the main mafic phase. Despite the calc-alkaline signature a mild alkaline affinity emerges from some whole-rock trace elements content and from mineral chemistry (amphibole, clinopyroxene and titanomagnetite compositions). The magmatic evolution of the Lonco Trapial andesites, dacites and trachydacites was governed by fractionation of amphibole, clinopyroxene, plagioclase, titanite, titanomagnetite and apatite. Amphibole phenocrysts show an overall normal chemical zoning. The cores of the amphiboles crystallized over a temperature range of $869-916^{\circ} \mathrm{C}$, whereas the rims crystallized over a temperature range of $826-867{ }^{\circ} \mathrm{C}$. Shallow to intermediate depths $(2-8 \mathrm{kbar}, \sim 7-26 \mathrm{~km})$ were inferred from geobarometric calculations. Crystallization temperatures are slightly higher in the clinopyroxene-bearing volcanic rocks, consistent with their more primitive character. The geobarometric estimations of this work are coherent with the lack of marine ingressions and with geophysical estimations which suggest that the Early Jurassic Moho depth would have been $\geq 35 \mathrm{~km}$ The combination of whole-rock and mineral geochemistry is consistent with an extensional affinity for this paleo-volcanic belt.
\end{abstract}

\section{Introduction}

Early Jurassic times in Patagonia were characterized by widespread magmatism linked to the early stages of Gondwana break-up. This magmatism is known as the Chon Aike Volcanic Province, one of the largest rhyolitic provinces in the world, which also extends to the Antarctic Peninsula (Pankhurst et al., 1998, 2000; Riley et al., 2001). The age of this magmatism becomes younger southwards, preceding the opening of the South Atlantic Ocean in the Early Cretaceous (Pankhurst et al., 2000). This volcanism starts in northeastern Patagonia in the
Early Jurassic, with the V1 volcanic event (188-178 Ma), and is coeval with the peak of the Karroo-Ferrar basaltic volcanism. It was then followed in southern Patagonia and northern Antarctic Peninsula by the Middle Jurassic volcanic event V2 (172-162 Ma), and by the Late Jurassic volcanic event V3 (157-153 Ma) which migrated to the Andes Cordillera (Féraud et al., 1999; Pankhurst et al., 2000 and references therein).

Central Patagonia is traversed by a $\mathrm{N}-\mathrm{S}$ belt of calc-alkaline intermediate volcanic rocks interspersed with more felsic volcanics and with sedimentary rocks known as the Lonco Trapial Formation (Page and

\footnotetext{
* Corresponding author. Instituto de Investigación en Paleobiología y Geología, Av. Julio A. Roca 1242, General Roca, 8332, Pcia. de Río Negro, Argentina.

E-mail address: cbzaffarana@gmail.com (C. Zaffarana).
} 


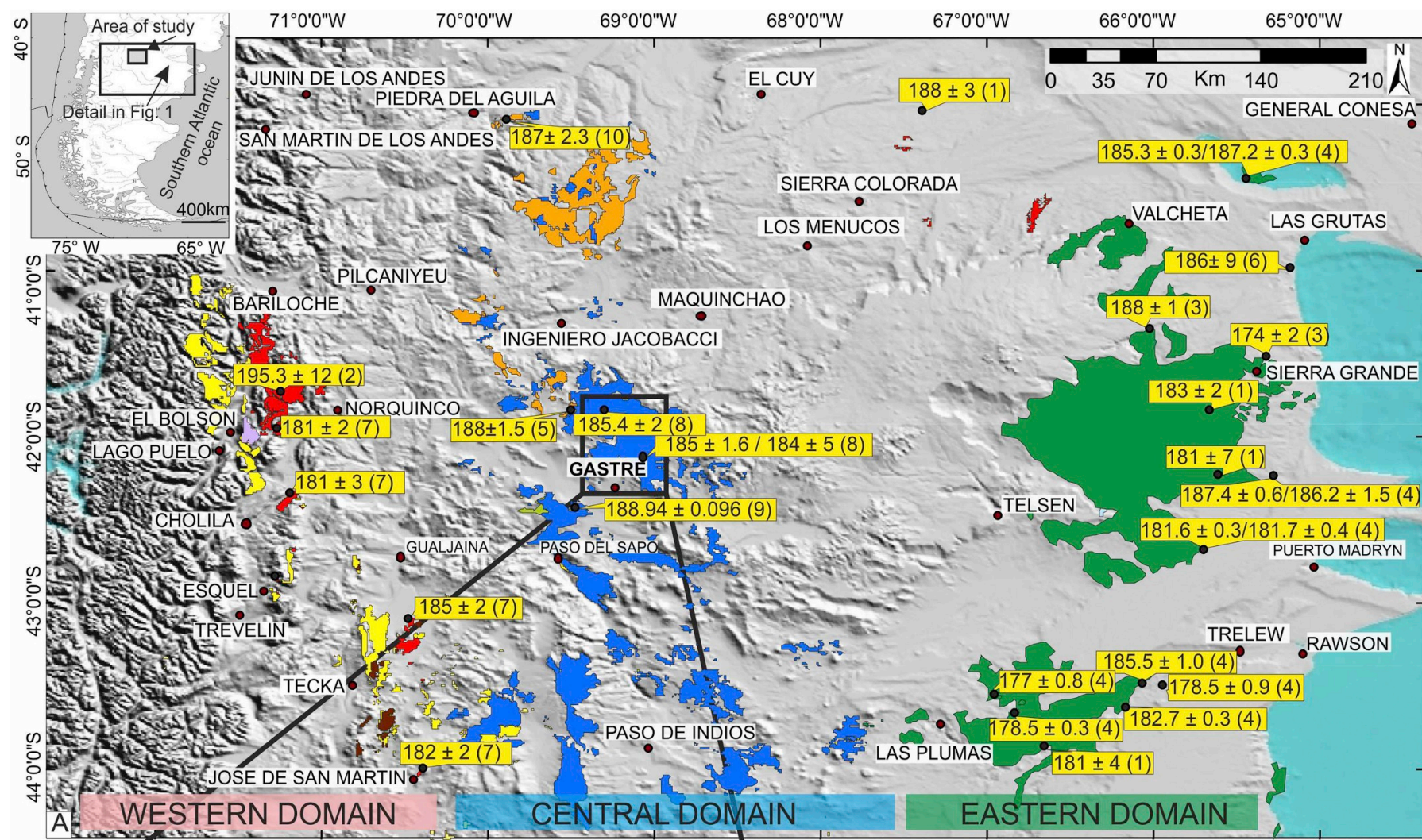

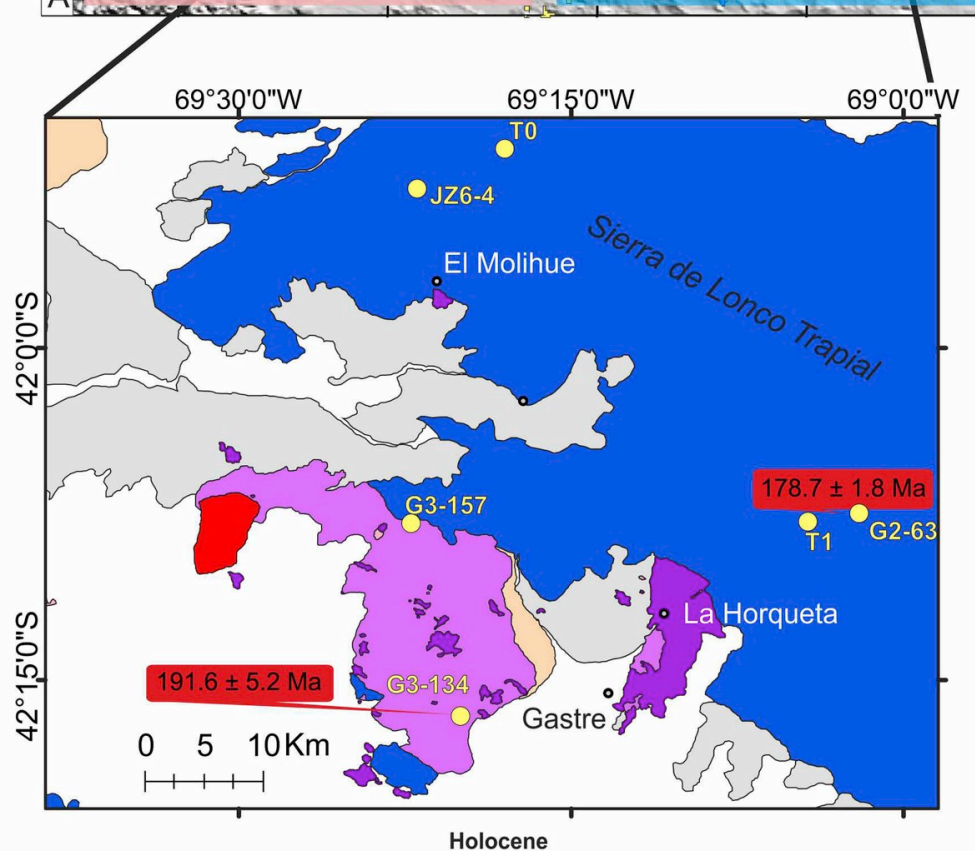

Holocene

Geochemical data (mineral a $\quad$ b a) Basalts b) Sediments chemistry complemented, Early to Middle Jurassic almost always, by wholerock geochemistry, see Table 1)

$$
\text { B }
$$$$
\text { Late Triassic }
$$

$$
\begin{aligned}
& \text { Undifferentiated granites } \\
& \begin{array}{|ll}
\hline \text { a } & \begin{array}{c}
\text { Central Patagonian b) Lipetrén Superun } \\
\text { Batholith }
\end{array} \\
\text { a) Gastre Superunit }
\end{array}
\end{aligned}
$$

\section{GEOLOGICAL REFERENCES OF THE REGIONAL MAP OF EARLY JURASSIC UNITS OF THE NORTH PATAGONIAN MASSIF (Fig. 1A)}

\section{Eastern domain}

Acidic and intermediate

volcanites: Marifil Formation

Felsic intrusives: (El Sótano Granodiorite, Flores Granite)

\section{Central domain}

Andesitic volcanic dominated facies: Lonco Trapial, Taquetrén, Cerro Carnerero, Cañadón Puelman and Cajón de Ginebra formations

Dacites and rhyolites: Garamilla Formation

Sedimentary rocks: Las Leoneras, Los Tobianos, Puesto Lizarralde formations

\section{Western domain}

\section{Felsic intrusives: Subcordilleran Plutonic Belt (Leleque Fm., Aleusco Granite)}

Mafic and ultramafic intrusives: Tecka and Cresta de los Bosques formations

Sedimentary rocks: Piltriquitrón, Lepá, Osta Arena formations

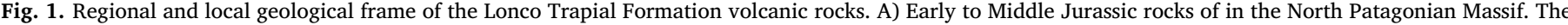

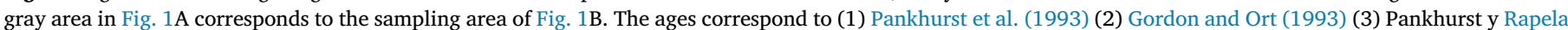

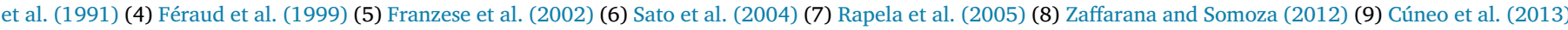
y (10) Benedini and Gregori (2013). B) Local map of the area of Gastre showing the distribution of samples and the studies performed. 
Table 1

General data of the samples collected: outcrop type, location, analyses performed, and age constraints. Mineral abbreviations after Whitney and Evans (2010).

\begin{tabular}{|c|c|c|c|c|c|c|c|c|}
\hline \multicolumn{2}{|l|}{ Analysis type } & $\mathrm{T} 1$ & T0 & G2-63 & G3-134 & JZ6-4 & \multicolumn{2}{|l|}{ G3-157 } \\
\hline \multicolumn{2}{|l|}{ Lithology } & Amp-bearing trachydacite & Amp-bearing dacite & Amp-bearing dacite & $\begin{array}{l}\text { Amp-bearing } \\
\text { andesite }\end{array}$ & $\begin{array}{l}\text { Amp-bearing } \\
\text { andesite }\end{array}$ & \multicolumn{2}{|c|}{ Cpx-bearing trachydacite } \\
\hline \multicolumn{2}{|l|}{ Outcrop } & Lava flow & Lava flow & Porphyry & Dike & Lava flow & \multicolumn{2}{|l|}{ Lava flow } \\
\hline \multirow{3}{*}{\multicolumn{2}{|c|}{$\begin{array}{l}\text { Latitude (degrees, South) } \\
\text { Longitude (degrees, West) } \\
\text { Whole-rock major analysis }\end{array}$}} & 42.1307 & 41.8500 & 42.1244 & 42.2769 & 41.8800 & \multicolumn{2}{|l|}{42.1318} \\
\hline & & 69.0719 & 69.3000 & 69.0335 & 69.3334 & 69.3660 & \multicolumn{2}{|l|}{69.3705} \\
\hline & & Actlabs & Actlabs & SGS Peru & SGS Peru & - & SGS Peru & \\
\hline \multirow{2}{*}{\multicolumn{2}{|c|}{ Age constraints }} & \multicolumn{2}{|c|}{$\begin{array}{l}{ }^{40} \mathrm{Ar}-{ }^{39} \mathrm{Ar} \text { Amp and paleomagnetic data in } \\
\text { Zaffarana and Somoza (2012) }\end{array}$} & $\begin{array}{l}{ }^{40} \mathrm{Ar}-{ }^{39} \mathrm{Ar} \\
\text { Amp-SERNAGEOMIN }\end{array}$ & $\begin{array}{l}\mathrm{K}-\mathrm{Ar} \text { whole } \\
\text { rock-Actlabs }\end{array}$ & \multirow{2}{*}{\multicolumn{2}{|c|}{$\begin{array}{l}\text { Form part of the paleomagnetic } \\
\text { data defining an Early Jurassic } \\
\text {-paleopole (Zaffarana and } \\
\text { Somoza, 2012) }\end{array}$}} & - \\
\hline & & $185 \pm 1.6 / 184 \pm 5$ & $185.4 \pm 2$ & $178.9 \pm 1.1$ & $191.6 \pm 5.2$ & & & \\
\hline \multirow[t]{3}{*}{$\begin{array}{l}\text { Mineral } \\
\text { analysis }\end{array}$} & $\begin{array}{l}\text { Electron } \\
\text { microprobe }\end{array}$ & - & - & Pl, Amp, Mag, Usp & - & - & & $\begin{array}{l}\text { Pl, Cpx, } \\
\text { Amp, } \\
\text { Mag, Usp }\end{array}$ \\
\hline & EDS data & - & - & Amp & - & Amp & & - \\
\hline & ICP-MS data & Amp & Amp & Amp & Amp & - & & - \\
\hline
\end{tabular}

Page, 1993). The Lonco Trapial lavas were considered the more mafic counterparts of the predominantly rhyolitic Chon Aike Volcanic Province and part of the V1 volcanic event (Gust et al., 1985; Pankhurst et al., 1998, 2000; Franzese et al., 2002; Zaffarana and Somoza, 2012; Benedini and Gregori, 2013; Cúneo et al., 2013; Bouhier et al., 2017). This volcanism was in a back-arc position with respect to the activity of a western short-lived Early Jurassic magmatic arc known as the Subcordilleran Plutonic Belt (Fig. 1a; Gordon and Ort, 1993; Haller et al., 1999; Rapela et al., 2005).

This work aims to refine the origins of the Lonco Trapial Formation volcanic rocks using new measurements of mineral and whole-rock major and trace element compositions (e.g. Sas et al., 2017). The sample suite comprises mainly Early Jurassic andesites, dacites and trachydacites from the locality of Gastre (Fig. 1b). Our data are used to constrain magma type, petrogenetic processes, magma storage conditions (temperature, pressure, $\mathrm{fO}_{2}$ ) and parental melt compositions. Our analysis recovers an extensional signature from these predominantly calc-alkaline magmas.

\section{Geological setting}

\subsection{Early Jurassic igneous and sedimentary units in the North Patagonian Massif}

The distribution of Early Jurassic rocks in Patagonia between $40^{\circ}$ and $44^{\circ} \mathrm{S}$ is shown in Fig. 1a. The Early Jurassic units of the North Patagonian Massif can be divided into three domains: eastern, central and western (Fig. 1a). Within the eastern domain, the Early Jurassic rocks are predominantly magmatic, comprised of the rhyolitic volcanic rocks of the Marifil Formation (Pankhurst et al., 1993; Pankhurst and Rapela, 1995; Féraud et al., 1999) and by their intrusive counterparts known as the El Sótano Granodiorite (Sato et al., 2004) and as the Flores Granite (Pankhurst et al., 1993).

In the central domain, the Early Jurassic rocks are predominantly volcanic and andesitic (Fig. 1a). Following Page and Page (1993), the Lonco Trapial Formation is used here to refer to the volcanic belt of predominantly intermediate composition of Central Patagonia. North of Gastre, the Lonco Trapial Formation intermediate volcanics interdigitate with the Early Jurassic felsic volcanics of Garamilla Formation (Nullo, 1978; Franzese et al., 2002; Benedini and Gregori, 2013). South of Gastre (near Paso del Sapo and further south), the Lonco Trapial Formation forms part of the early infill of the Cañadón Asfalto basin (Figari and Courtade, 1993; Cortiñas, 1996; Cúneo et al., 2013; Figari et al., 2015; Hauser et al., 2017; Bouhier et al., 2017), overlying the syn-rift deposits of Las Leoneras Formation (Cúneo et al., 2013, Fig. 1a).

The NNW-SSE Early Jurassic Pampa de Agnia basin extends to the western (and partly central) domain of the North Patagonian Massif (Fig. 1a, Vizán, 1998; Suárez and Márquez, 2007). The sedimentary rocks of the Pampa de Agnia basin are intruded by the Early Jurassic mafic-ultramafic suite of the Tecka and Cresta de los Bosques formations (Page, 1984; Poma, 1986; Féraud et al., 1999; Page and Page, 1999). The gabbros and sedimentary rocks are intruded by the Subcordilleran Plutonic Belt, a NNW-SSE trending batholith of Early Jurassic age (Fig. 1a; Gordon and Ort, 1993; Haller et al., 1999; Rapela et al., 2005). Lonco Trapial Formation lavas are in a back-arc position with respect to the activity of the Early Jurassic magmatic arc represented by the Subcordilleran Plutonic Belt (Fig. 1a).

\subsection{Local geology and sampling: the Lonco Trapial Formation in Gastre}

This work is focused on volcanic rocks from the Lonco Trapial Formation in Gastre (Fig. 1a). Here, the oldest rocks are Late Paleozoic metamorphic rocks of the Calcatapul (Proserpio, 1978) and Cushamen formations (Volkheimer, 1964; López de Luchi and Cerredo, 2008). Two later magmatic suites include: the Late Paleozoic granites of the Gondwanic cycle and the Late Triassic granites of the Central Patagonian Batholith (Rapela et al., 1991; Rapela and Pankhurst, 1992; Pankhurst et al., 2006; López de Luchi and Cerredo, 2008; Zaffarana et al., 2017). The Jurassic volcano-sedimentary Lonco Trapial Formation (Taquetrén Formation of Nullo and Proserpio, 1975; Proserpio, 1978) rests on a highly irregular paleosurface carved into these granitoids.

The Lonco Trapial Formation in Gastre hosts a volumetrically important eruptive suite associated with thick volcaniclastic conglomerates. The volcanic facies are mainly represented by andesitic lavas and breccias, while the subvolcanic facies consist of many porphyries and dikes of the same composition. There are also subordinate pyroclastic facies composed of tuffaceous beds mainly corresponding to dacitic ignimbrites. Representative samples collected in this study correspond to lava flows (T1, T0, JZ6-4 and G3-157), dikes (G3-134) and porphyries (G2-63). A summary of the ages, locations and studies that were performed is presented in Table 1, and locations are shown in Fig. 1.

\section{Analytical techniques}

Whole-rock major and trace elements were determined using ICP, ICP-MS and ICP-AES at Activation Laboratories, Ontario, Canada (ACTLABs) and at the SGS laboratory (Peru). Results are presented in 
Table 1-Appendix.

Sample G2-63 was dated by ${ }^{40} \mathrm{Ar}-{ }^{39} \mathrm{Ar}$ in amphibole at the Geochronological Laboratory of SERNAGEOMIN (Chile) and sample G3-134 was dated by whole-rock K-Ar at Actlabs (Ontario, Canada). In the former, the system is equipped with two extraction lines of radiogenic Ar gas, which are aligned with a Stanelco induction furnace, with a maximum power of $7.5 \mathrm{~kW}$. The extracted Ar is purified through two extraction lines of Ar and is analyzed in a semi-automatic mass spectromet er where the total content of ${ }^{40} \mathrm{Ar}$ in the sample is detected (radiogenic ${ }^{40} \mathrm{Ar}$ and ${ }^{40} \mathrm{Ar}$ atmospheric). The measurement of $\mathrm{K}$ in the sample is analyzed in an equivalent aliquot, through X-ray fluorescence in the Chemical Laboratory of SERNAGEOMIN.

Mineral phases were analyzed by WDS at the Technical-Scientific Services of Oviedo University (Spain) using a Cameca SX-100 electron microprobe with a voltage intensity of $15 \mathrm{kv}$, current of $15 \mathrm{nA}$, and acquisition time of $10 \mathrm{~s}$ per element. A combination of silicates and oxides was used for calibration. Results are presented in Table 2-Appendix.

ICP-MS laser ablation measurements of amphibole separates were done at the GZG, University of Göttingen (Germany) on a Perkin Elmer DRC II equipped with a Lambda Physics Compex $110 \mathrm{Ar}-\mathrm{F}$ Laser at $193 \mathrm{~nm}$, using a Geol-Las optical bank. Ar carrier gas was used and a low-volume custom-made sample chamber. Individual elements were measured after $10 \mathrm{~ms}$ dwell time with an integration time for the measured signal of $60 \mathrm{~s}$ (on average). The estimated major element composition ( $\mathrm{Si}$ ) of the respective mineral was used as internal standard. Results are presented in Table 3-Appendix.

EDS data of amphibole crystals were obtained in the Centro de Microscopías Avanzadas (CMA), Facultad de Ciencias Exactas y Naturales, Universidad de Buenos Aires (FCEN-UBA). The equipment is characterized by an Energy Dispersive X-Ray Microanalysis hardware (EDS), Inca Energy, Oxford Instruments, coupled with a SEM Zeiss Supra 40 scanning electron microscope equipped with a field emission gun. The images were taken with in-lens detector and $5 \mathrm{kV}$ acceleration voltage. The applied standards were $\mathrm{CaCO}_{3}$ for $\mathrm{C}, \mathrm{SiO}_{2}$ for $\mathrm{O}$ and $\mathrm{Si}$, $\mathrm{Al}_{2} \mathrm{O}_{3}$ for $\mathrm{Al}$, wollastonite for $\mathrm{Ca}, \mathrm{MgF}_{2}$ for $\mathrm{F}$ and $\mathrm{MgO}$ for Mg. Results are presented in Table 4-Appendix.

\section{K-Ar and Ar-Ar dating}

The age of Lonco Trapial Formation is constrained between Early and Middle Jurassic time (Page and Page, 1993; Bouhier et al., 2017). In this work we dated some samples that confirmed an Early Jurassic age within the V1 volcanic event (Pankhurst et al., 2000). This period was characterized by ongoing magmatism to the west (Subcordilleran Plutonic Belt, Fig. 1).

Sample G2-63 presented a good ${ }^{40} \mathrm{Ar}-{ }^{39} \mathrm{Ar}$ plateau age for amphibole of $178.9 \pm 1.1 \mathrm{Ma}\left(94.1 \%\right.$ of ${ }^{39} \mathrm{Ar}$ released on 5 of the 9 steps, MSWD $=0.49$; Fig. 2a, Table 1 ). The integrated age is $175.9 \pm 1.4 \mathrm{Ma}$, and the isochron age is $178.7 \pm 1.8 \mathrm{Ma}$ (MSWD $=0.63$, with 5 out of 9 steps). The steps disregarded in the isochron and plateau ages are the low temperature ones, representing only $4.9 \%$ of the total ${ }^{39} \mathrm{Ar}$ released. The ${ }^{40} \mathrm{Ar} /{ }^{36} \mathrm{Ar}$ intercept is a bit higher than the atmospheric ratio ( $300 \pm 40$, Fig. 2 b), suggesting that some excess argon is present in the amphiboles, however, the three ages broadly coincide. The accepted age for this sample is the plateau age.

The andesitic dike represented by sample G3-134 yielded a $\mathrm{K}-\mathrm{Ar}$ whole-rock age of $191.6 \pm 5.2 \mathrm{Ma}\left(\% \quad \mathrm{~K}=1.88,{ }^{40} \mathrm{Ar}\right.$ radiogenic $=14.492 \mathrm{ml} / \mathrm{g}, \%{ }^{40} \mathrm{Ar}$ air $\left.=37.6\right)$. Sample T0 yielded an ${ }^{40} \mathrm{Ar}-{ }^{39} \mathrm{Ar}$ age in amphibole of $185.39 \pm 0.99 \mathrm{Ma}$, whereas sample $\mathrm{T} 1$ presented two overlapping ${ }^{40} \mathrm{Ar}-{ }^{39} \mathrm{Ar}$ ages for amphibole of $184 \pm 5 \mathrm{Ma}$ and of $182.8 \pm 1.3 \mathrm{Ma}$ (Zaffarana and Somoza, 2012). The reported ages are consistent with the paleomagnetic pole location, as the paleomagnetic vector isolated in sample JZ6-4 is consistent with the Early Jurassic mean direction in the area of study. This sample was part of the data set used to define an Early Jurassic paleomagnetic pole

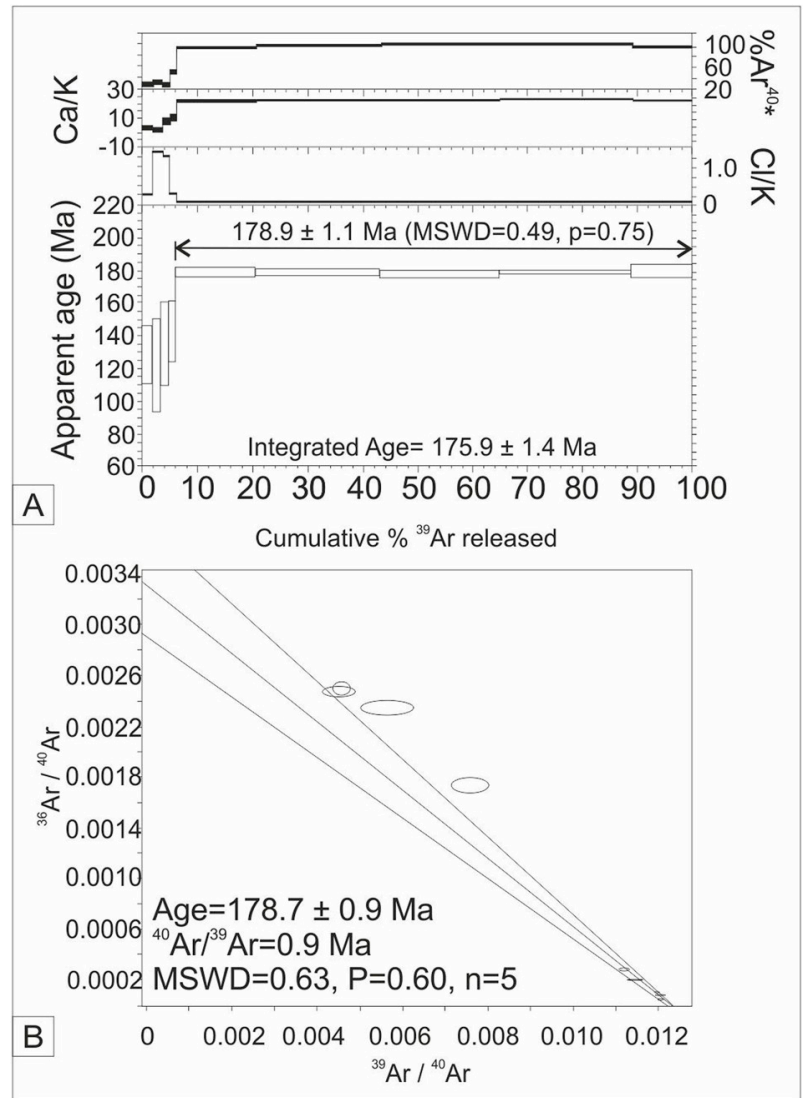

Fig. 2. ${ }^{40} \mathrm{Ar}-{ }^{39} \mathrm{Ar}$ age spectrum and isochron obtained from single mineral grains from the andesitic lava of the Lonco Trapial Formation of sample G2-63.

by Zaffarana and Somoza (2012) (Table 1). The clinopyroxene-bearing sample G3-157 was intercalated within the amphibole-bearing volcanic rocks typical of Lonco Trapial Formation in Gastre, therefore a Lower Jurassic age is expected for this sample.

\section{Classification and petrography}

The volcanic rocks of Lonco Trapial Formation have porphyritic ( $\sim 50$ modal \% phenocrysts) to glomeroporphyritic textures (Fig. 3). They have been classified as andesite, dacites and trachydacites in the major element classification diagram (TAS, Fig. 4a). Andesitic lavas and dikes have either amphibole (amphibole-bearing volcanic rocks) or clinopyroxene (clinopyroxene-bearing volcanic rocks) as the main mafic mineral. Even though both types coexist, the amphibole-bearing volcanic rocks are the most common.

The rocks are mainly composed by plagioclase $(40-60 \%$ of the phenocryst population), whose phenocrysts are euhedral to subhedral and can be up to $3 \mathrm{~mm}$ in size (Fig. 3a and b). They commonly display optical zoning, signs of resorption and disequilibrium margins, as well as synneusis, sieve textures and albitic rings and rims (the albitic compositions are shown by sample G2-63; Fig. 3a and b). The rocks contain either amphibole phenocrysts $(40-10 \%$ of the phenocryst assemblage) with phenocrysts of plagioclase and/or biotite and clinopyroxene (amphibole-bearing rocks; Fig. 3a, c) or clinopyroxene phenocrysts associated with plagioclase phenocrysts and tiny amphibole microphenocrysts (clinopyroxene-bearing rocks; e.g. G3-157; Fig. 3b, d). Table 1-Appendix summarizes mineral assemblages.

Amphibole-bearing rocks are characterized by a subhedral light green to brown pleochroic amphibole (Fig. 3c) with occasional Fe-Ti slight oxide rims and common polysynthetic twinning. Optical zoning is commonly seen, as in samples G2-63 and T1 (Fig. 3c, e). Phenocrysts are commonly preserved as whole crystals, however, in some samples 


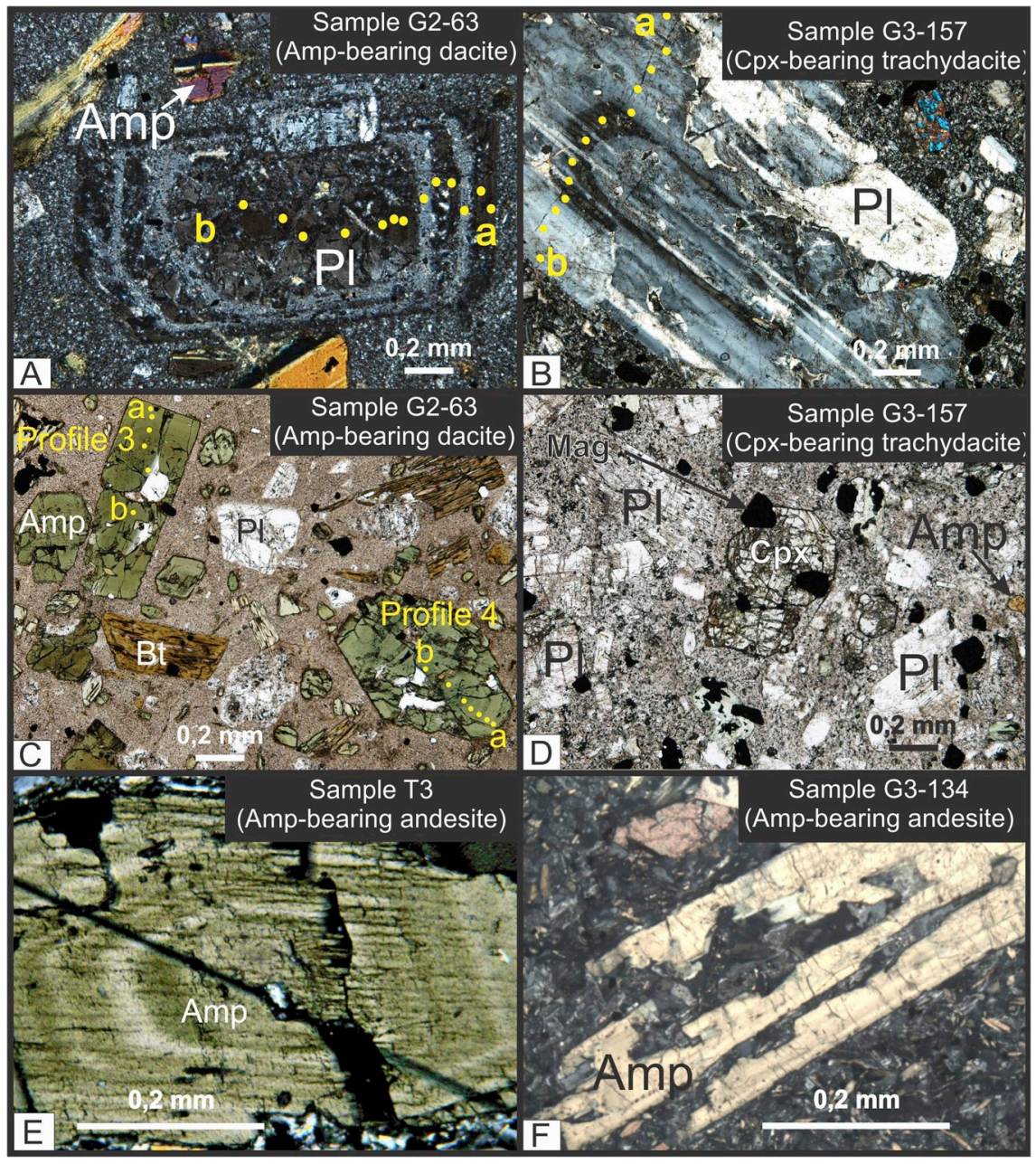

Fig. 3. Petrography of the andesitic lavas of the Lonco Trapial Formation. Photomicrographs taken under crossed polars and plane-polarized light. Yellow points in (A), (B) and (C) mark the sites studied with the electron microprobe. A) Plagioclase phenocryst with inner albitic rings, amphibole-bearing dacite G2-63. B) Plagioclase phenocrysts with synneusis and complex zoning, clinopyroxene-bearing trachydacite G3-157. C) Plagioclase, biotite and green amphibole phenocrysts in sample G263. D) Clinopyroxene-bearing trachydacite G3-157 with clinopyroxene and plagioclase phenocrysts and amphibole and titanomagnetite microphenocrysts. E) Detail of optically zoned amphibole in the amphibole-bearing andesite T3. F) Detail of skeletal amphibole phenocrysts. Amphibole-bearing andesite G3-134. Mineral abreviations after Whitney and Evans (2010). Amp: amphibole, $\mathrm{Pl}$ : plagioclase, Cpx: clinopyroxene, Bt: biotite, Mag: magnetite. (For interpretation of the references to colour in this figure legend, the reader is referred to the Web version of this article.) they are skeletal (e.g., G3-134; Fig. 3f). Where present, biotite is brown pleochroic and may be altered to iron oxides. Clinopyroxene occurs as relict cores in amphibole phenocrysts (e.g., sample G3-134).

Clinopyroxene-bearing rocks contain $\sim 20 \%$ of small euhedral clinopyroxene phenocrysts (sample G3-157; Fig. 3b, d). Coexisting amphibole occurs only as scarce brown and pleochroic microphenocrysts (Fig. 3d; G3-157).

Groundmass textures of both varieties are microcrystalline, sometimes pilotaxitic or hyalopilitic, composed of microliths of the same mineral assemblages as the phenocrysts (Fig. 3). Accessory minerals are titanomagnetite, titanite and apatite. The latter occurs as euhedral, stubby apatite crystals, either isolated in the groundmass or as inclusions in plagioclase phenocrysts. Interstitial glass is commonly replaced by sericite and clays. All samples are moderately altered to a propylitic assemblage given by chlorite, carbonate, secondary titanite, quartz, epidote, albite and opaque minerals. The alteration is mainly found in the groundmass while phenocrysts are essentially fresh, except the biotite, whose phenocrysts appear replaced by chlorite and opaque minerals (e.g., G2-63), so that no fresh biotite analyses could be obtained.

\section{Bulk rock geochemistry}

Major element geochemistry suggests that the Lonco Trapial volcanics are medium potassium andesites to dacites, and also trachydacites (Fig. 4a and b) with $\mathrm{SiO}_{2}$ between 58.57 and $63.17 \%$, $\mathrm{K}_{2} \mathrm{O}<2.30 \%, \mathrm{Al}_{2} \mathrm{O}_{3}>16.12 \%$, and $\mathrm{Na}_{2} \mathrm{O}$ varying from 3.86 to $5.27 \%$ (anhydrous basis; Table 1-Appendix). All are metaluminous (average ASI index 0.86; Table 1-Appendix) and silica oversaturated, having quartz and hypersthene, apatite and ilmenite in their CIPW normative compositions. It should be noted that the classification based on immobile element ratios of (Winchester and Floyd, 1977) essentially agrees with the major element classification (Fig. 4c).

In the TAS diagram, rock compositions cluster around the alkalinesubalkaline boundary (Fig. 4a). They are calc-alkaline magmas in the sense of Miyashiro (1974, Fig. 4d). Their $\mathrm{FeO}_{\mathrm{t}} / \mathrm{MgO}$ vs $\mathrm{SiO}_{2}$ content is variable, and their CA/TH index (Hora et al., 2009) is between 0.93 and 2.23, so they belong to medium-to low-Fe calc-alkaline series (Arculus, 2003, Table 1-Appendix, Fig. 4d).

Their chondrite-normalized REE patterns (McDonough and Sun, 1995) have negative slopes, being variably enriched in LREE and depleted in HREE $\left[(\mathrm{La} / \mathrm{Yb})_{\mathrm{N}}=14-7\right]$ (Fig. 5a, Table 1-Appendix) and subtle Eu anomalies, which can be either slightly negative or positive $\left(\mathrm{Eu} / \mathrm{Eu}^{*}=1.1-0.9\right.$; Table 1-Appendix $)$. The fractionation mainly involves the light and middle REE $\left[(\mathrm{La} / \mathrm{Dy})_{\mathrm{N}}=10-4\right]$, whereas the heavy REE pattern is rather flat or slightly positive from $\mathrm{Ho}$ to $\mathrm{Lu}[\mathrm{CHo} /$ $\left.\mathrm{Lu})_{\mathrm{N}}=1.3-0.95\right]$ causing a concave up curvature (Fig. 5a, Table 1Appendix). Decreasing Dy/Yb with increasing $\mathrm{SiO}_{2}$, and the decreasing $\mathrm{Dy} / \mathrm{Yb}$ and Dy/Dy* (Dy* = value interpolated; Davidson et al., 2013, Fig. 5c, Table 1-Appendix) with differentiation, which is roughly orthogonal to the depletion-enrichment trend would indicate that the rocks are cogenetic according to Davidson et al. (2013) (Fig. 5b and c). The concave up shape of REE patterns, the decreasing $[\mathrm{Dy} / \mathrm{Yb}]_{\mathrm{N}}$ (1.71-1.25) with increasing $\mathrm{SiO}_{2}$ (Fig. 5b), and the low Dy/Dy* values (Dy* = value interpolated; Davidson et al., 2013, Fig. 5c, Table 1Appendix) point out the role of amphibole \pm clinopyroxene fractionation and the absence of garnet, fractionated or residual in the melting source (Davidson et al., 2013). 


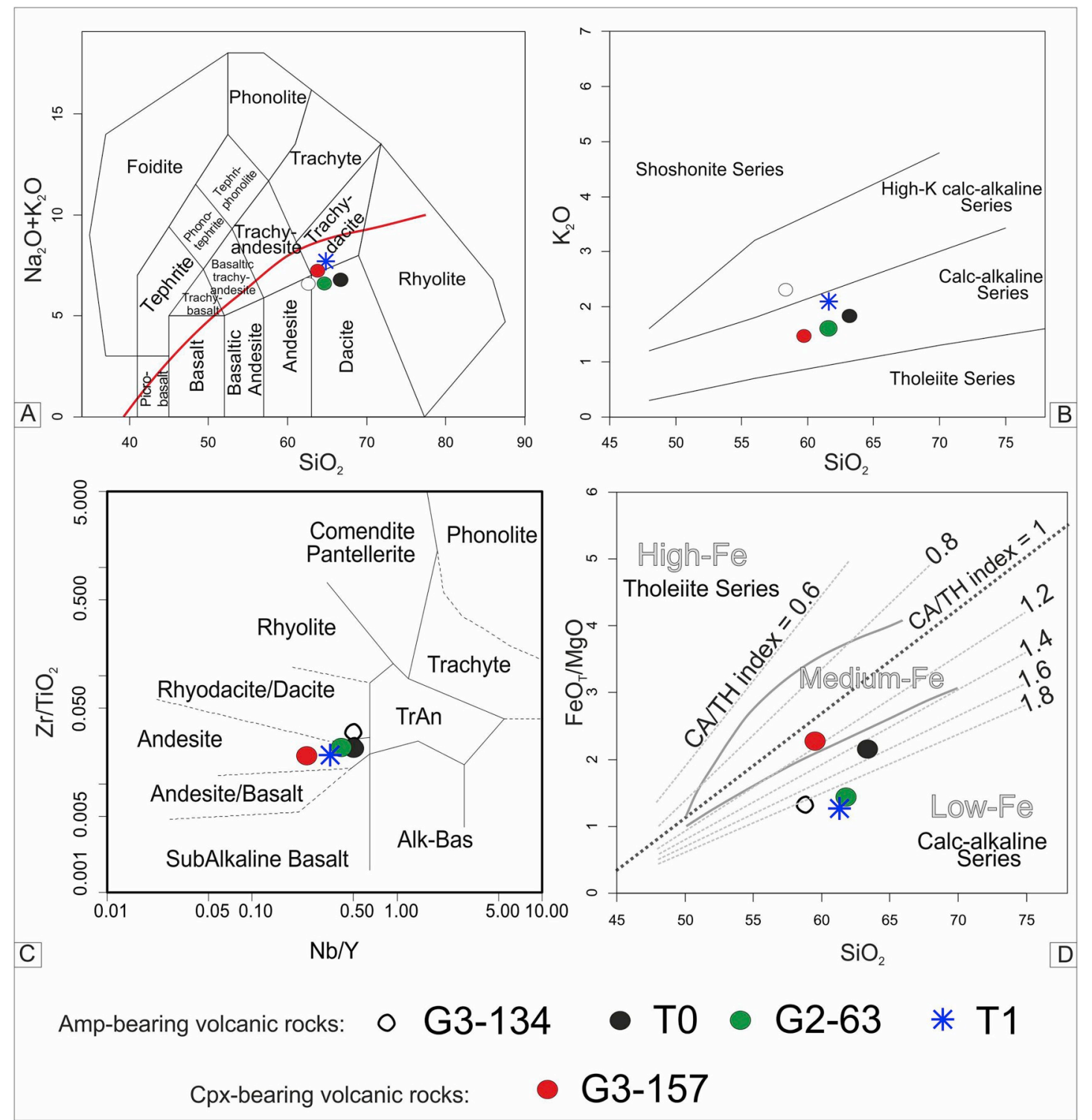

Fig. 4. General geochemical classification of the Lonco Trapial lavas based on whole-rock major and trace-element data. A) Total alkalis versus silica (TAS) diagram with classification of the studied rocks. Alkaline-subalkaline dividing line after Irvine and Baragar (1971). B) $\mathrm{K}_{2} \mathrm{O}$ vs. silica diagram (Peccerillo and Taylor, 1976) showing that the Lonco Trapial volcanics are medium-to high-K calc-alkaline magma series. C) Trace element classification of Winchester and Floyd (1977). D) Plot of the Lonco Trapial volcanics relative to calc-alkaline and tholeiitic fields of Miyashiro (1974) and high-, medium- and low-Fe fields of Arculus (2003). Dashed lines indicate uniform CA/TH index (Hora et al., 2009).

Trace element patterns show a general behavior that is typical of rocks of the calc-alkaline series, with LILE enrichment, negative $\mathrm{Nb}$ and Ta anomalies (except Ta in sample G3-134) and with a positive spike in $\mathrm{Pb}$ (Fig. 5d). The Lonco Trapial samples also show lesser contents of $\mathrm{Ti}$, $\mathrm{Y}$ and $\mathrm{Yb}$ than N-MORB (Sun and McDonough, 1989, Fig. 5d). Samples G3-157 and G3-134 are richer in Th, U, Zr, Ti, Y, REE and also in Ta (in sample G3-134) with respect to the other samples, showing contents similar to those presented by alkaline rocks. This affinity also arises from the chemical composition of their phenocrysts, as will be shown below.

\section{Mineral compositions}

Representative electron microprobe analyses of plagioclase, amphibole, clinopyroxene and titanomagnetite are presented in Table 2Appendix, ICP-MS analyses of amphiboles from representative samples are presented in Table 3-Appendix and EDS analyses of amphiboles are shown in Table 4-Appendix.

\subsection{Amphibole major and trace element compositions}

Amphibole structural formulas were calculated on the basis of $23 \mathrm{O}$ after the method of Dale et al. (2005) and with all Ca in the M4 site (Table 2a-Appendix). Amphibole compositions are calcic, with $\mathrm{Fe}_{\mathrm{t}} /$ $\left(\mathrm{Fe}_{\mathrm{t}}+\mathrm{Mg}\right)$ in the $0.30-0.47$ range and have moderate to high $\mathrm{TiO}_{2}$ contents $(0.85-1.65 \%$ and 0.10 to 0.17 a. p.f.u. in amphibole-bearing dacite G2-63; $3.25-3.77 \%$ and $0.36-0.42$ a. p.f.u. in clinopyroxenebearing trachydacite $\mathrm{G} 3-157)$. The $\mathrm{Fe}^{3+} /\left(\mathrm{Fe}^{3+}+\mathrm{Fe}^{2+}\right)$ ratio is moderate in the amphibole-bearing dacite G2-63 (between 0.45 and 0.25 ) and low in clinopyroxene-bearing trachydacite G3-157 (between 0.08 and 0.15 ). Amphiboles in amphibole-bearing volcanic rocks (G2-63) are tschermakite (mostly the cores) to magnesiohornblende (Fig. 6a), whereas in clinopyroxene-bearing volcanic rocks (G3-157) they are magnesiohastingsite (Fig. 6b). Amphibole compositions in the samples analyzed by EDS (all amphibole-bearing volcanic rocks) are more varied but similar to the EMP analyses. They are all classified as magnesiohornblende (Fig. 6a). 

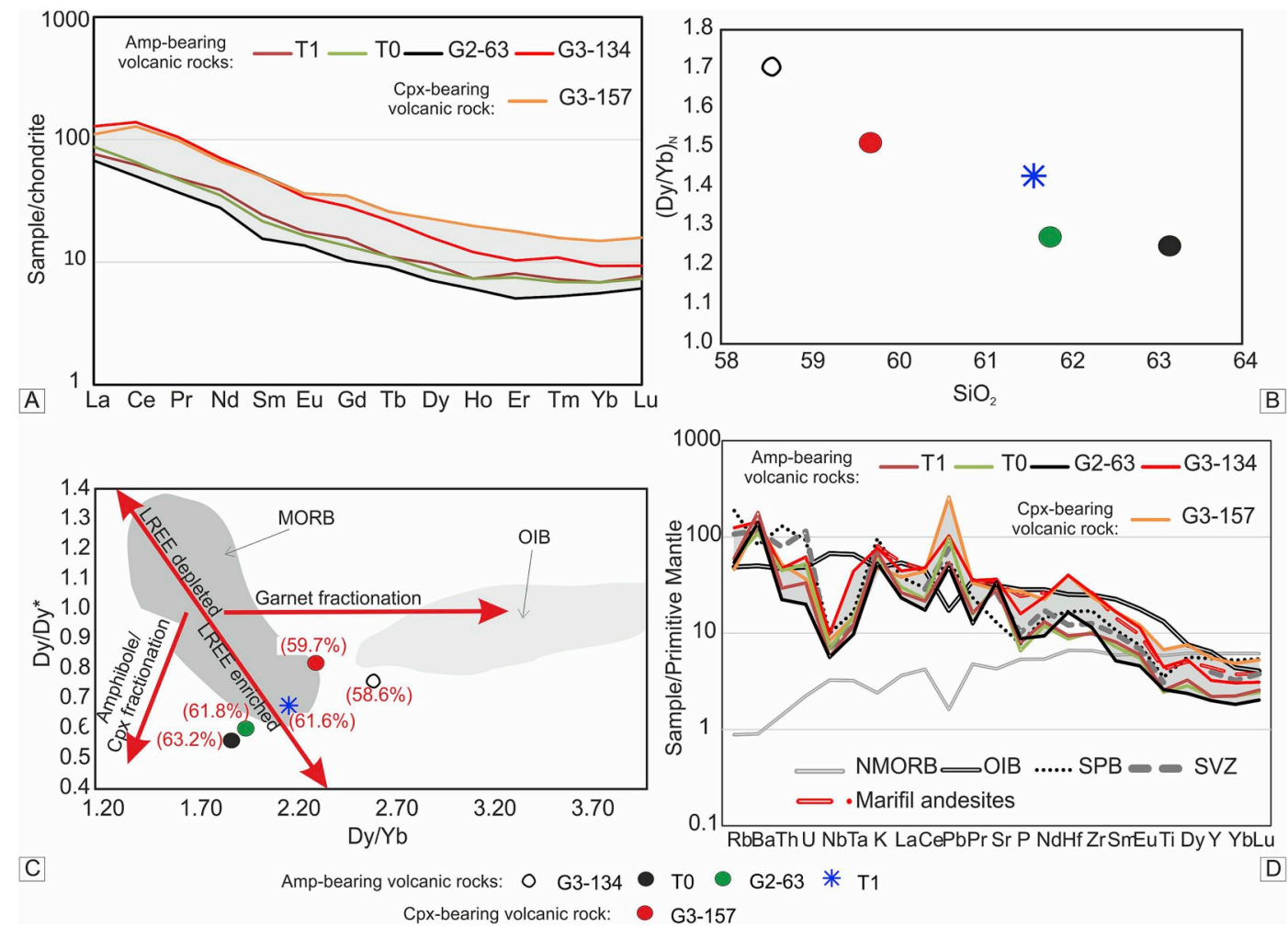

Fig. 5. Trace element composition of the Lonco Trapial andesitic lavas. A) REE pattern of the analyzed rocks normalized to chondrite. B) Negative trend in the [Dy/ $\mathrm{Yb}] \mathrm{N}$ vs. $\mathrm{SiO}_{2}$ diagram indicative of amphibole fractionation (Davidson et al., 2013). C) Plot of Dy/Dy* vs. Dy/Yb with extended Dy/Yb scale to show fields for MORB and OIB (Davidson et al., 2013). The percentages in red above or below each sample represent their silica content. D) Primitive Mantle normalized multielemental plot. NMORB and OIB curves (Sun and McDonough, 1989) are shown for comparison, together with data from the Subcordilleran Plutonic Belt (SPB; Haller et al., 1999; Rapela et al., 2005), the present Southern Volcanic Zone (SVZ; Wörner et al., 1988) and of the andesites comprised within the Marifil Formation (Pankhurst and Rapela, 1995). Chondrite normalization was taken from McDonough and Sun (1995) and Primitive Mantle normalization was taken from Sun and McDonough (1989). (For interpretation of the references to colour in this figure legend, the reader is referred to the Web version of this article.)

In all amphiboles, the charges due to the introduction of the $\mathrm{Al}$ tetrahedral site occupancy seems to be balanced by a combination of the edenitic and tschermakitic substitutions (Fig. 6c). In some samples (G3-157 and JZ6-4) the $\mathrm{Al}^{\mathrm{IV}}$ in amphibole is slightly controlled by $\mathrm{TiO}_{2}$ content (Fig. 6d). The amphiboles show a general normal zoning pattern where the core is richer in $\mathrm{Al}$ and $\mathrm{Ti}$ and poorer in $\mathrm{Si}$ and $\mathrm{Fe}$ than the rim (Fig. 1-Appendix).

All amphiboles present moderate REE abundances and slightly negative europium anomalies (Fig. $7 \mathrm{a}$; Eu/Eu* ranging from 0.69 to 0.89 ). Amphiboles in samples G2-63 and T1 have similar REE patterns with a convex upward shape, as amphiboles are depleted in light REE and enriched in middle REE (Fig. 7a). In contrast, the amphibole from sample T0 shows upward concavity in the heavy REE and a less marked convex upward shape in the light REE (Fig. 7a). In turn, sample G3-134 has a steeper heavy REE slope and a less pronounced Eu anomaly (Fig. 7a). Incompatible trace element patterns of the amphiboles normalized to the Primitive Mantle (Sun and McDonough, 1989) display positive $\mathrm{Ba}, \mathrm{Nb}, \mathrm{Pr}, \mathrm{Ce}, \mathrm{Nd}$ and $\mathrm{Sm}$ anomalies, and negative $\mathrm{Rb}, \mathrm{Sr}, \mathrm{Zr}, \mathrm{U}$ and Th anomalies (Fig. 7b). The amphiboles from samples G3-134 and T0 have greater content of $\mathrm{Th}, \mathrm{U}, \mathrm{Pb}$, and $\mathrm{Yb}$ and $\mathrm{Lu}$ (only sample T0 shows the last two; Fig. 7b).

\subsection{Plagioclase, clinopyroxene and titanomagnetite compositions}

Plagioclase compositions were calculated on the basis of $32 \mathrm{O}$ (Table 2b-Appendix). Plagioclases in the amphibole-bearing dacite (G263) are mainly andesine from cores (An46) to rims (An30), with some rounded and resorbed labradorite cores (An55), and internal concentric zones or outer rims of albite (An3-1) (Fig. 2a and b-Appendix; Table 2bAppendix). Plagioclase compositions in the clinopyroxene-bearing trachydacite G3-157 range from labradorite-andesine (An55-37) in the cores to andesine-oligoclase in the rims (An46-29; Fig. 2c-Appendix, Table 2b-Appendix).

Clinopyroxene analyses from the clinopyroxene-bearing trachydacite G3-157 are presented in Table 2c-Appendix and compositions were calculated on the basis of $6 \mathrm{O}$. According to $\mathrm{Ca}(0.80-0.85$ a. p.f.u.), $\mathrm{Mg}$ (0.83-0.87 a. p.f.u.), $\mathrm{Fe}^{2+}(0.25-0.29$ a. p.f.u.) and $\mathrm{Na}(0.017-0.028$ a. p.f.u.) contents, they are augite (Morimoto, 1988) with $\mathrm{Mg} \#$ rather homogeneous $(\sim 0.73-0.77)$. As in the amphiboles of this sample, the content of $\mathrm{Al}^{\mathrm{IV}}$ is balanced by the content of $\mathrm{TiO}_{2}$ (Fig. 6e).

Titanomagnetite belongs optically to the stage 1 of homogeneous $\mathrm{TiO}_{2}$-rich magnetite or to stage 2 of magnetite-enriched solid solutions with a small number of exsolved ilmenite lamellae (Haggerty, 1991). Titanomagnetite compositions, calculated on the basis of $4 \mathrm{O}$ (Table $2 \mathrm{~d}$ Appendix), correspond to $\mathrm{TiO}_{2}$-rich magnetites $\left(\mathrm{Y}=\mathrm{Fe}^{+3}\right.$ is greater than $75 \%$, and $\mathrm{Ti}$ content of the crystals is generally higher than $0.2 \mathrm{a}$. p.f.u.). When plotted in the triangular diagram of $\mathrm{FeO}, \mathrm{TiO}_{2}, \mathrm{Fe}_{2} \mathrm{O}_{3}$ (Fig. 6f) titanomagnetite compositions represent the solid-solution between magnetite and ülvospinel. These solid solutions exist above $600{ }^{\circ} \mathrm{C}$ (Buddington and Lindsley, 1964).

\section{Discussion}

\subsection{Geochemical signature of Lonco Trapial magmas}

The andesites, dacites and trachydacites of Lonco Trapial Formation are calc-alkaline rocks (Fig. 4a). When compared to the Primitive Mantle, the rocks show, as other calc-alkaline suites, pronounced enrichment in $\mathrm{Sr}, \mathrm{Ba}$ and $\mathrm{Pb}$ and strong depletion in $\mathrm{Nb}$ and $\mathrm{Ta}$ (Fig. 4d). Moderate LILE enrichment, typical of calc-alkaline magmas, is also 

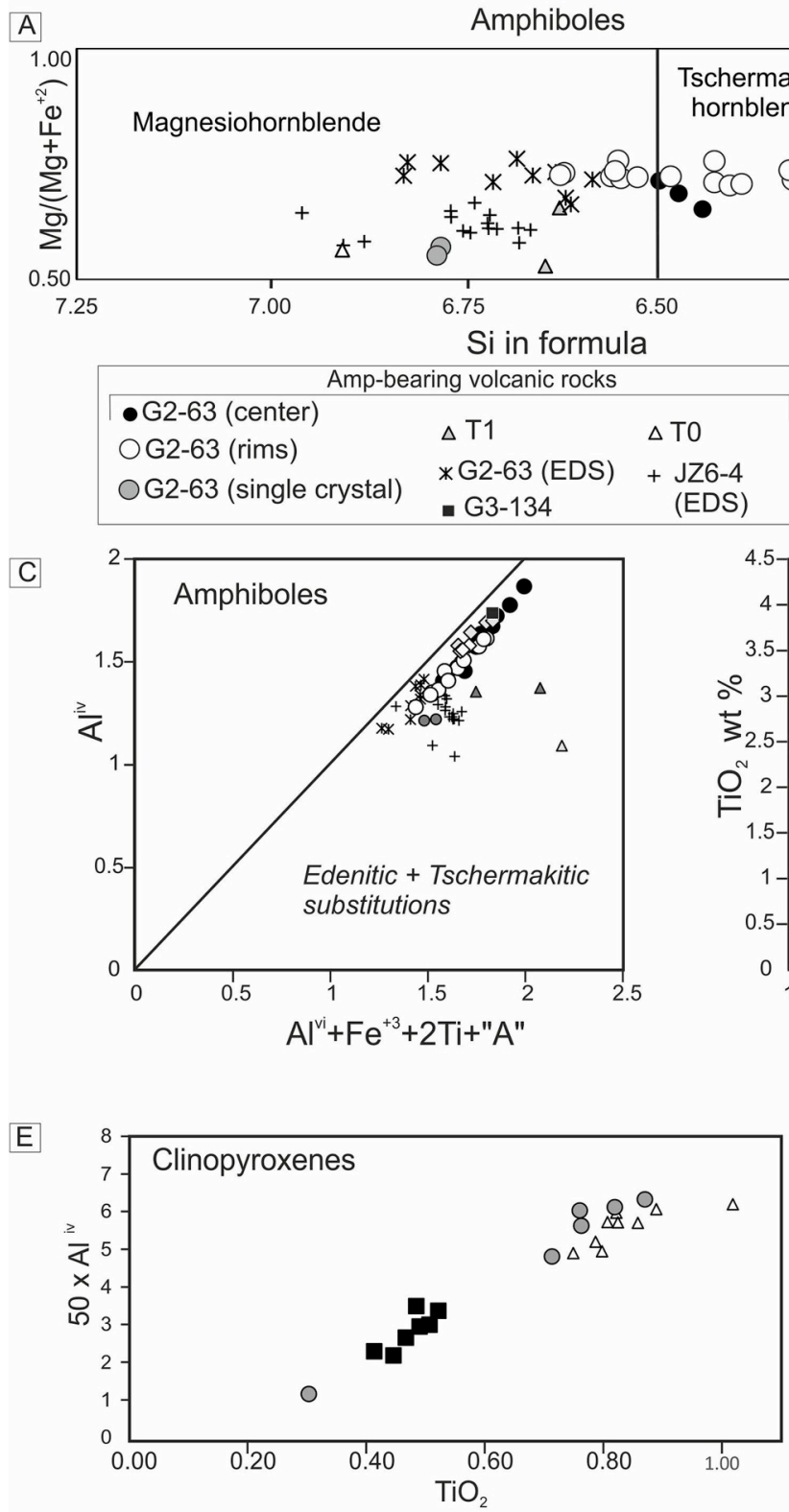

-G3-157-Profile $1 \Delta$ G3-157-Profile 2 oG3-157-Profile 3 (Cpx-trachydacite)
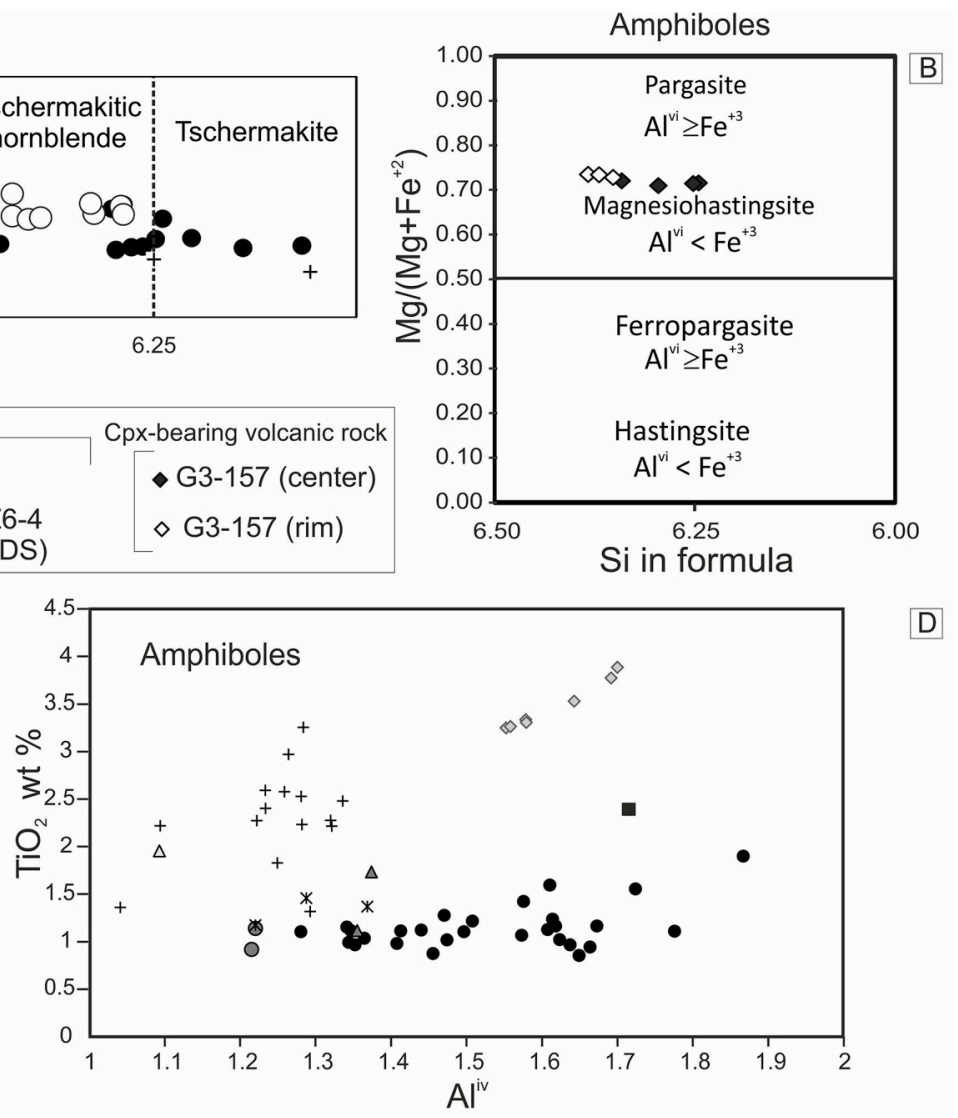

D

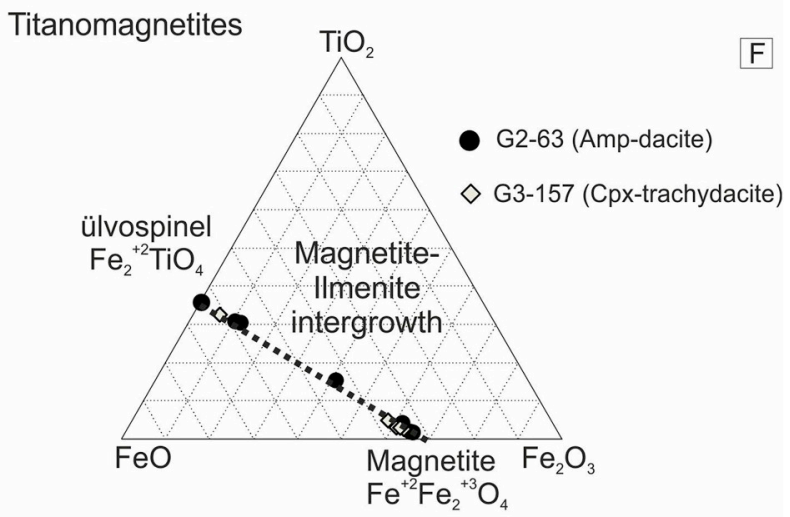

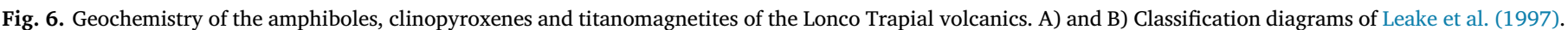

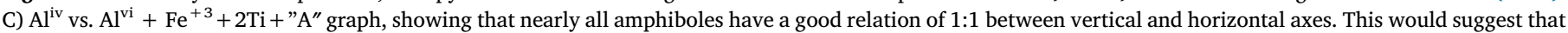

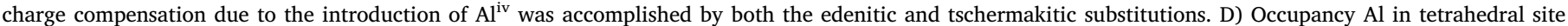

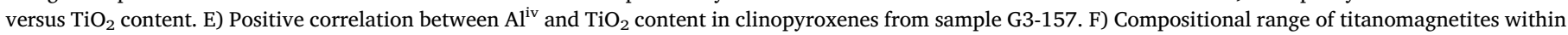
the $\mathrm{FeO}-\mathrm{Fe}_{2} \mathrm{O}_{3}-\mathrm{TiO}_{2}$ diagram (wt \%).

shown in the chondrite-normalized spider diagram (Fig. 5a). Trace element ratios are characteristic of calc-alkaline magmas, given by high $\mathrm{La} / \mathrm{Ta}(\mathrm{La} / \mathrm{Ta}>25$ except G3-134: Table 1-Appendix), $\mathrm{Ba} / \mathrm{Nb}>40$, $\mathrm{La} / \mathrm{Nb}>1$ and $\mathrm{Th} / \mathrm{Nb}>0.5$ and low $\mathrm{Nb} / \mathrm{Zr}(<0.05$, except G2-63) and $\mathrm{Ce} / \mathrm{Pb}<20$ ratios (Table 1-Appendix). Similarly, the samples display decreasing Dy/Dy* and Dy/Yb trends with differentiation, orthogonal to the MORB trend (which goes from depleted to enriched light REE, Fig. 5c) characteristic of calc-alkaline magmas (Davidson et al., 2013).

Even though the calc-alkaline signature of Lonco Trapial lavas is strong, some intraplate characteristics are also present. Whole-rock trace element ratios show that some samples present $\mathrm{Ta} / \mathrm{Hf}>0.15$ which is distinctive of intraplate magmas (e.g., Kay et al., 2006).
Sample G3-134 has a Dy/Yb ratio (2.6) which is close to the OIB field (Fig. 5c). However, the rest of the samples have low Dy/Yb ratios (2.3-1.9) which are characteristic of calc-alkaline magmas.

As phenocrysts of volcanic rocks would have formed in the early stages of the magmatic history, any inference about the chemistry of the magma coming from them would be useful. When compared with amphiboles of different tectonic settings, the Lonco Trapial amphiboles coincide with those of calc-alkaline rocks (Fig. 8; Demény et al., 2012). However, mineral chemistry proves to be particularly sensitive in unraveling some alkaline affinity of the Lonco Trapial lavas. For example, $\mathrm{TiO}_{2}$ content in amphiboles and clinopyroxenes is a good indicator of magma alkalinity (Molina et al., 2009). Amphibole from the clinopyroxene-bearing trachydacite G3-157 and of the amphibole-bearing 

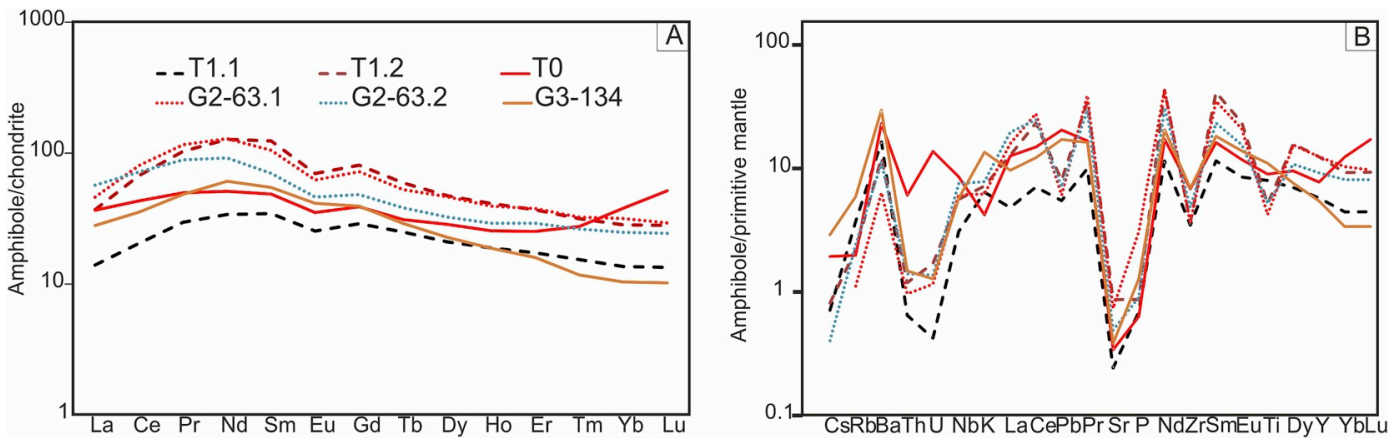

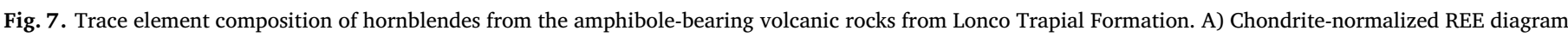
(McDonough and Sun, 1995). B) Primitive Mantle normalized multielemental diagram (Sun and McDonough, 1989).

volcanic rocks G3-134 and JZ6-4 have crystallized from subalkaline trachytoid to alkaline magmas (Fig. 9a-d), whereas the amphiboles from the amphibole-bearing volcanic rocks G2-63, T0 and T1 crystallized mostly from subalkaline magmas (Fig. 9a-d). Consistently, clinopyroxenes of the clinopyroxene-bearing trachydacite G3-157 also crystallized from magmas transitional between subalkaline and alkaline (Molina et al., 2009) (Fig. 9e). These clinopyroxenes also crystallized from calc-alkaline orogenic magmas transitional to intraplate magmas according to the diagrams of Le Bas (1962) (Fig. 9f), Nisbet and Pearce (1977) (Fig. 9g) and Leterrier et al. (1982) and (Fig. 9h-i).

We interpret that Lonco Trapial lavas were erupted within widespread rifting conditions. In addition, they are located in the rear arc of a paleo-subduction zone represented by the Subcordilleran Plutonic Belt. The origin of the Lonco Trapial magmas can be ascribed to two different settings (or combinations): 1) a rifting phase, where the mantle source rocks were affected by previous subduction processes and 2) a rifting phase, where the calc-alkaline signature is inherited by assimilation of crustal rocks (a mixed source). Around Gastre, two different previous orogenic cycles could have produced mantle metasomatism in the area. These cycles produced the Late Paleozoic granites of the Gondwanide orogeny (López de Luchi and Cerredo, 2008; Pankhurst et al., 2006; Rapela et al., 1991; Rapela and Pankhurst, 1992), and the pre-rifting Late Triassic granites of the Central Patagonian Batholith (Rapela et al., 1991; Rapela and Pankhurst, 1992; Pankhurst et al., 2006; Zaffarana et al., 2014, 2017).

Crustal contamination, in turn, is suggested by the $\mathrm{Nb} / \mathrm{Ta}$ ratios of the Lonco Trapial lavas (average $\sim 8$; Table 1-Appendix). $\mathrm{Nb} / \mathrm{Ta}$ ratios are lower than in arc-related basalts and OIB (arc basalts have an average $\mathrm{Nb} / \mathrm{Ta}$ of $\sim 15$; Munker et al., 2004; whereas the continental crust has a Nb/Ta reference value of 11.4; Rudnick and Gao, 2003). Therefore, $\mathrm{Nb} / \mathrm{Ta}$ ratios suggest crustal assimilation in the origin of the magmas (e.g. see Moreno et al., 2016, for further discussion). The

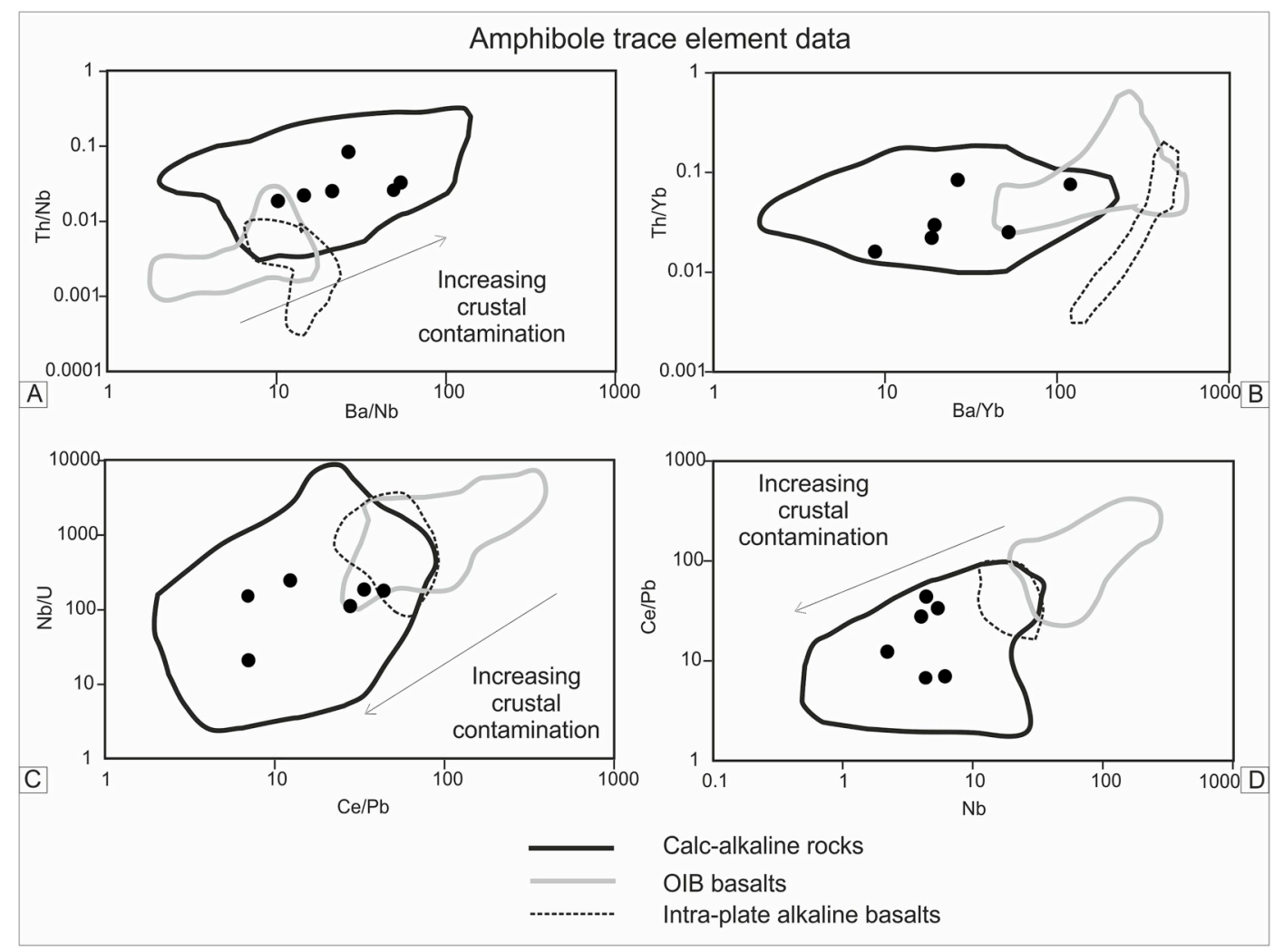

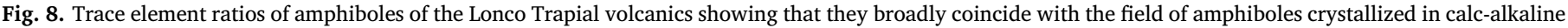

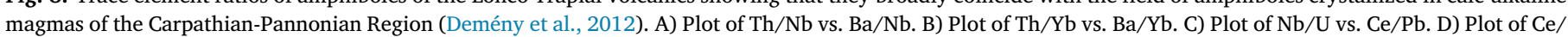

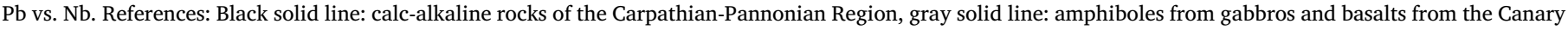
Islands and dashed line: alkaline basalts of the Carpathian-Pannonian Region (Demény et al., 2012). 
Amphibole tectonic discrimination diagrams
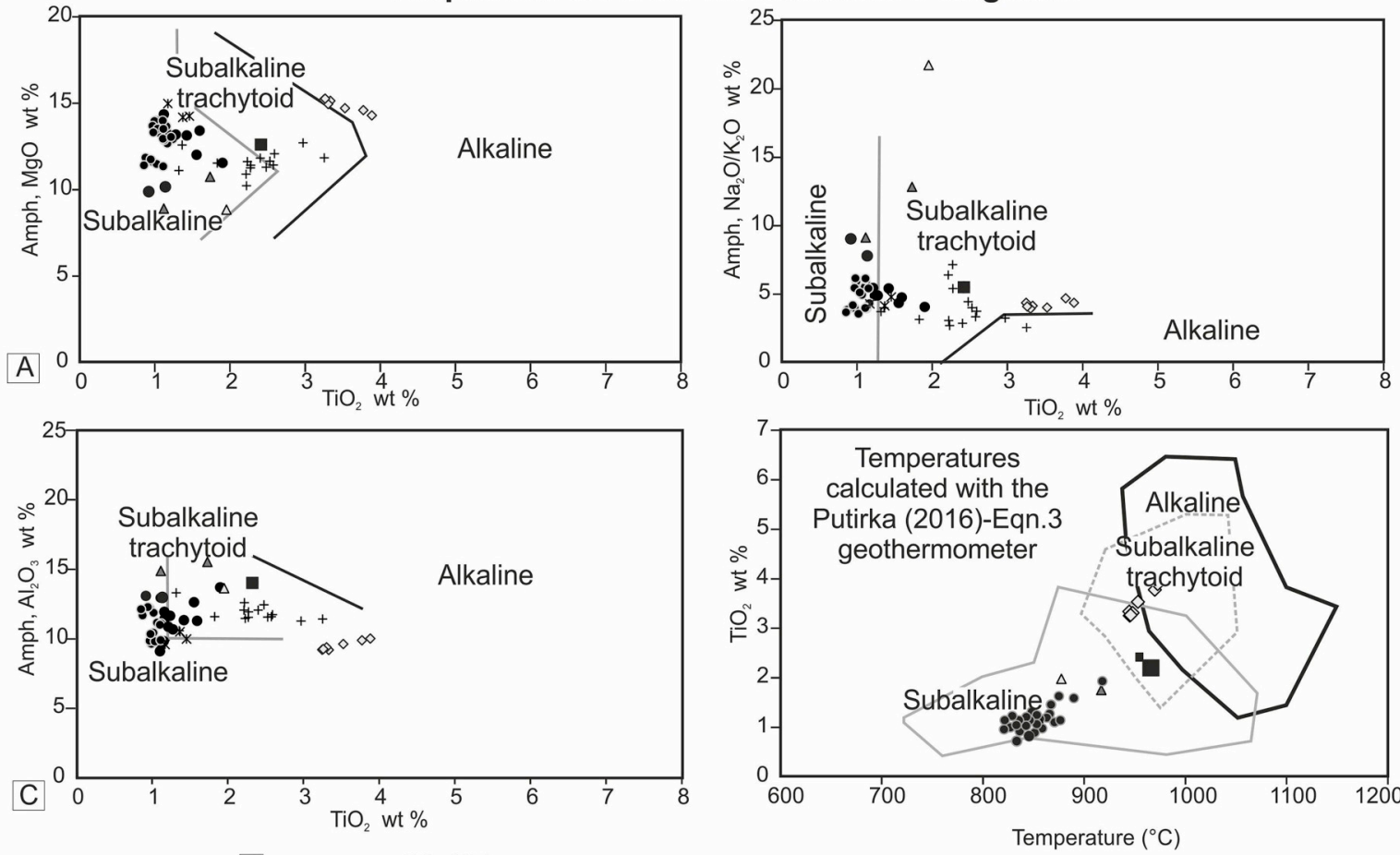

D

$\underset{\text { volcanic rocks: }}{\text { Amp-bearing }}\left[\begin{array}{cc}\bullet \mathrm{G} 2-63 & \bullet \mathrm{G} 3-134 \quad \Delta \mathrm{T} 0 \\ \Delta \mathrm{T} 1 & * \mathrm{G} 2-63(\mathrm{EDS})\end{array}+\mathrm{JZ6}-4(\mathrm{EDS})\right.$

$\diamond \mathrm{G} 3-157$ (Cpx-bearing volcanic rock)

Clinopyroxene tectonic discrimination diagrams (for Cpx-trachydacite G3-157)
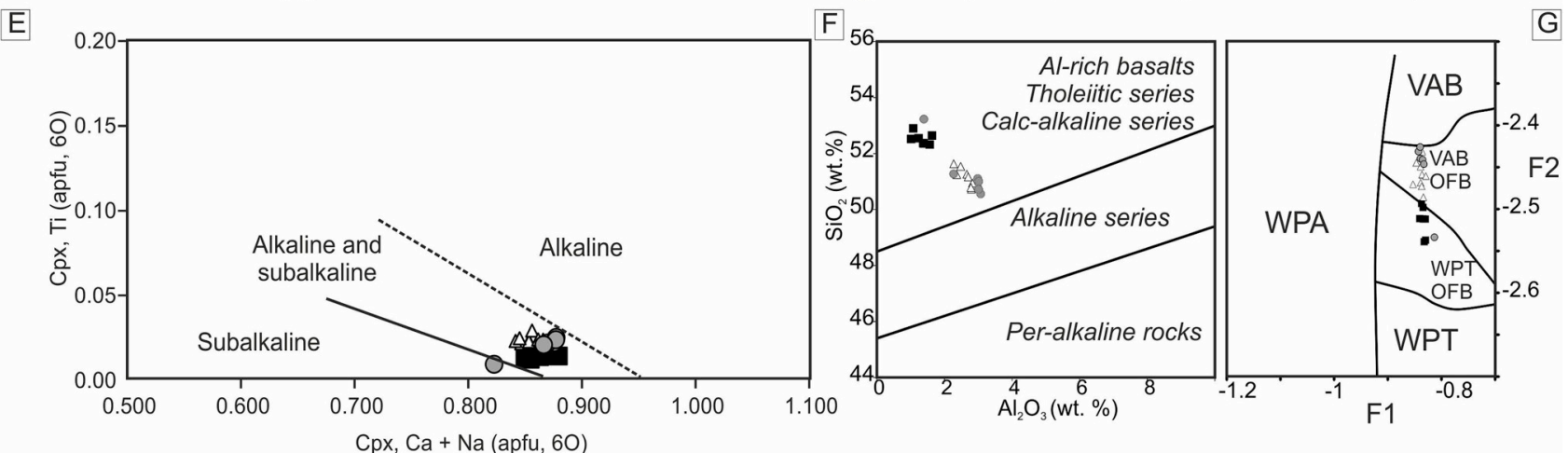

$\mathrm{H}$
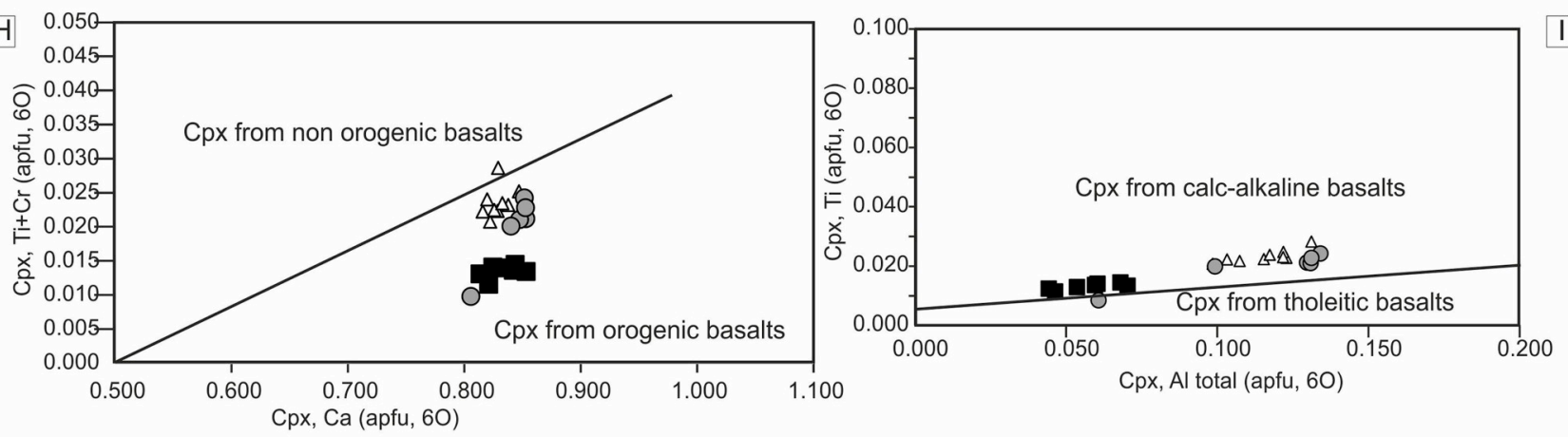

-G3-157-profile 1

$\Delta$ G3-157-profile 2 o G3-157-profile 3

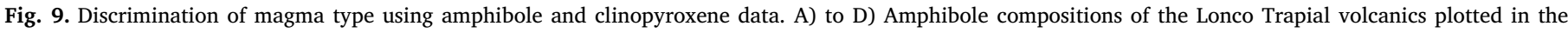

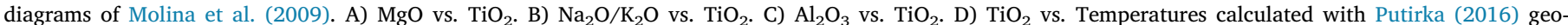

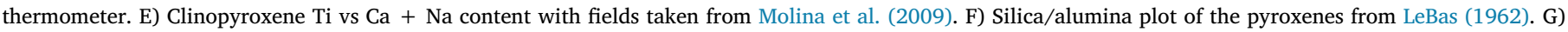

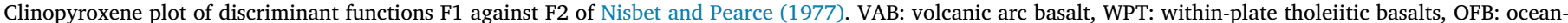

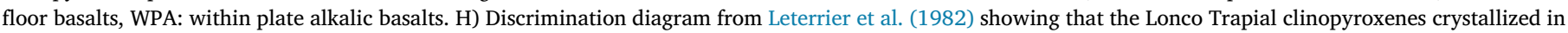

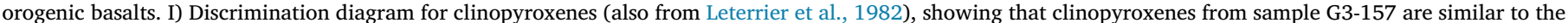
ones crystallized in calcalkaline basalts. 
variation in the amphibole multielemental pattern (Fig. 7b) would support mixing of magmas of different origin (mantle and crustal generated magmas) in the genesis of the Lonco Trapial volcanic rocks. Even though the corroded appearance of some of the amphiboles can be due to decompression, it could also be attributed to magma mixing, as well as the disequilibrium textures shown by the plagioclases. Furthermore, the Middle Jurassic andesites associated with the Cañadón Asfalto rift basin show field, petrographic and geochemical characteristics attributable to crustal assimilation (Bouhier et al., 2017). These authors explained the arc signatures of Lonco Trapial magmas as due to assimilation of crustal rocks supported by the recognition of zircon xenocrysts with Permian and Middle- Upper Triassic ages (281.3 Ma, 246.5, 218.1, and 201.3 Ma) within these volcanic rocks. The isotopic data from Dejonghe et al. (2002) also suggested that the Lonco Trapial magmas are a mixture of mantle and crustal-derived magmas.

Other rock suites generated in extensional environments bear a calcalkaline geochemical signature. For example, the Variscan appinites from Iberia (Bea et al., 2006; Molina et al., 2012; Scarrow et al., 2009), and the quartz-monzonites from the Katerina Ring Complex, southern Sinai, Egypt (Moreno et al., 2014, 2016). There, the magmatism was generated in a post-collisional regime, but in both cases the calc-alkaline signature suggests an important involvement of a continental crust component in the magmas. Nevertheless, metasomatism in the mantle source due to a previous subduction event should not be ruled out anyway.

\subsection{Parental melt compositions, oxygen fugacity and fractionating phases}

The amphiboles are products of crystallization in calc-alkaline magmas. The equilibrium magmatic conditions and melt composition are calculated from the spreadsheet Amp-TB. xls of Ridolfi et al. (2010) (Fig. 10a). The method also estimates the oxygen fugacity conditions of the melt (Fig. 8b). In the amphibole-bearing dacite (G2-63), the amphibole cores coexisted with liquid of andesitic to dacitic composition (Fig. 10a, Table 2), while some rim compositions (G2-63) are in equilibrium with a melt of dacitic to rhyolitic composition (Fig. 10a). In turn, core and rim compositions of the small amphibole phenocrysts of the clinopyroxene-bearing trachydacite G3-157 crystallized in equilibrium with melts of dacitic composition (Fig. 10a). The amphiboles from the two samples crystallized in high $\mathrm{fO}_{2}$ conditions between the NNO and NNO + 2 curves (Fig. 10b; Ridolfi et al., 2010), consistent with oxygen fugacity values inferred for calc-alkaline magmas ( $\triangle \mathrm{NNO}$ from -1 to +3 ; e.g. Gill, 1981; Behrens and Gaillard, 2006). The low $\mathrm{Fe}_{\mathrm{t}} /\left(\mathrm{Fe}_{\mathrm{t}}+\mathrm{Mg}\right)$ ratios also indicate that amphiboles crystallized at high$\mathrm{fO}_{2}$ conditions (Anderson and Smith, 1995), in consonance with the presence of titanomagnetite as the main oxide phase (see below, Fig. 10c).

Amphibole/melt partition coefficients for La, Yb, Sm, Eu and Gd for different kinds of melts are available in the literature (see overview in Tiepolo et al., 2007). Hornblende partition coefficients strongly vary with melt compositions (Sisson, 1994). To minimize this problem, the $[\mathrm{La} / \mathrm{Yb}]_{\mathrm{N}}$ and the $\mathrm{Eu} / \mathrm{Eu}^{*}$ anomaly of the melt in equilibrium with the amphiboles was estimated using Kd for different melt compositions and then it was compared with the whole-rock compositions (Table 3). Although it is difficult to get precise estimations of melt $[\mathrm{La} / \mathrm{Yb}]_{\mathrm{N}}$ ratios and $\mathrm{Eu} / \mathrm{Eu}^{*}$ anomalies due to the large scattering in $\mathrm{Kd}$ values, there are some tendencies that can be analyzed. For instance, in the more evolved rocks, the $[\mathrm{La} / \mathrm{Yb}]_{\mathrm{N}}$ ratio calculated for interstitial melts is lower than the whole-rock ratio, implying that the light REE become more compatible than the heavy REE. This is a fact that cannot be ascribed to amphibole fractional crystallization, and which can be attributed to the fractional crystallization of titanite, which is a mineral phase which concentrates light REE (Bea, 1996).

Assuming a theoretical dacitic composition for the interstitial melt, which is reasonable, because after amphibole and plagioclase crystallization the melt becomes more acidic than the parental melt, a strong Eu fractionation occurs with respect to Sm and Gd. This would imply plagioclase saturation of the magma (Table 2). The $\mathrm{Eu} / \mathrm{Eu}^{*}$ values close to 1 in the whole-rock (Table 2) would suggest a lesser plagioclase fractionation, which is consistent with plagioclase behavior in andesitic melts rich in water (Sisson and Grove, 1993; Molina et al., 2009), where it decreases its appearance temperature by $>100{ }^{\circ} \mathrm{C}$ (Sisson and Grove, 1993). This further agrees with the REE modelling, which suggests that plagioclase crystallization took place with ongoing crystallization. Amphibole REE patterns do show negative Eu anomalies (Fig. 7a), that could be ascribed either to concomitant plagioclase fractionation (see, for example, Schnetzler and Philpotts, 1970), or to the low $\mathrm{Kd}$ for Eu that amphibole has in andesitic and basandesitic melts (i.e. Tiepolo et al., 2007 and references therein). These REE patterns in amphibole could also be ascribed to mixing with, or assimilation of crustal material (that already had fractionated plagioclase) before amphibole crystallization.

Amphibole \pm clinopyroxene fractionation during differentiation was suggested by the decreasing $[\mathrm{Dy} / \mathrm{Yb}]_{\mathrm{N}}$ with increasing $\mathrm{SiO}_{2}$ (Fig. 5b), and by the low Dy/Dy*, and the trend of decreasing Dy/Dy* with decreasing $\mathrm{Dy} / \mathrm{Yb}$ (with increasing $\mathrm{SiO}_{2}$; Davidson et al., 2013, see Fig. 5c). Amphibole fractionation, together with crustal contamination, can be another cause of the low $\mathrm{Nb} / \mathrm{Ta}$ ratio of the Lonco Trapial magmas (average 8; Table 1-Appendix, Li et al., 2017; see the previous section).

Apatite fractionation is another cause of middle REE fractionation in metaluminous magmas (Bea, 1996). The fractionation of this mineral is also suggested by the high apatite saturation temperatures which were obtained from the amphibole-bearing volcanic rocks (Table 3, see below). The low apatite saturation temperatures in the clinopyroxenebearing trachydacite G3-157 contrast with the presence of abundant stubby apatite crystals in the groundmass of this sample. This would suggest that even though the liquid represented by the whole-rock would not be saturated in apatite, the interstitial liquid in equilibrium with amphibole would have reached apatite saturation temperatures. In addition, the compatible behavior of P (not shown) would indicate apatite fractionation. No zircon fractionation could be inferred from zircon saturation temperatures (see below), which are very low and close to the solidus in amphibole-bearing and well as in clinopyroxenebearing volcanic rocks, nor from the petrographic analysis (no zircon crystals could be observed in the rocks). Therefore, the compatible character of $\mathrm{Zr}$ (not shown) can be ascribed, then, to amphibole crystallization (Bea et al., 2006).

All in all, co-crystallization of amphibole, plagioclase, titanite, titanomagnetite and apatite is suggested by amphibole depletion in $\mathrm{Sr}$, $\mathrm{Zr}, \mathrm{U}, \mathrm{Th}$ and Ti (with some exceptions, see Fig. 7b) and by the compatible character of $\mathrm{Zr}$ and $\mathrm{P}$. It is therefore concluded that differentiation processes in the Lonco Trapial volcanic rocks were controlled by a combination of amphibole, clinopyroxene, plagioclase, titanite, titanomagnetite and apatite fractionation.

\subsection{Magma storage temperatures and pressures}

Calc-alkaline andesites and dacites commonly show amphiboles with complex zoning and reaction textures such as the ones present in Lonco Trapial volcanic rocks. Reasonable estimations of environmental $(\mathrm{P}, \mathrm{T}, \mathrm{fO} 2)$ and compositional parameters (liquid composition in equilibrium with amphibole) can be recovered from amphiboles of this kind by careful selection of mineral compositions (see for example Blundy 

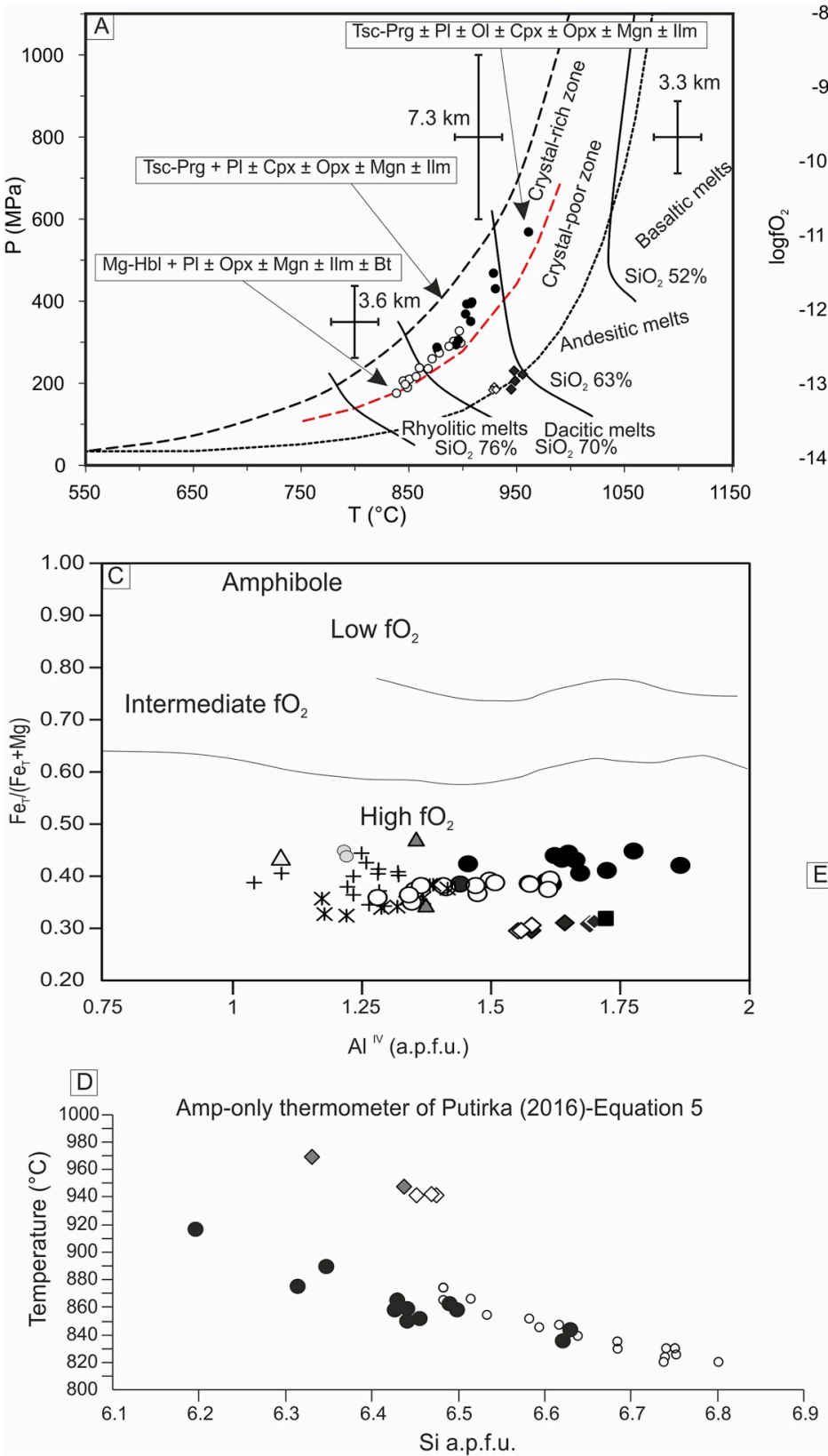

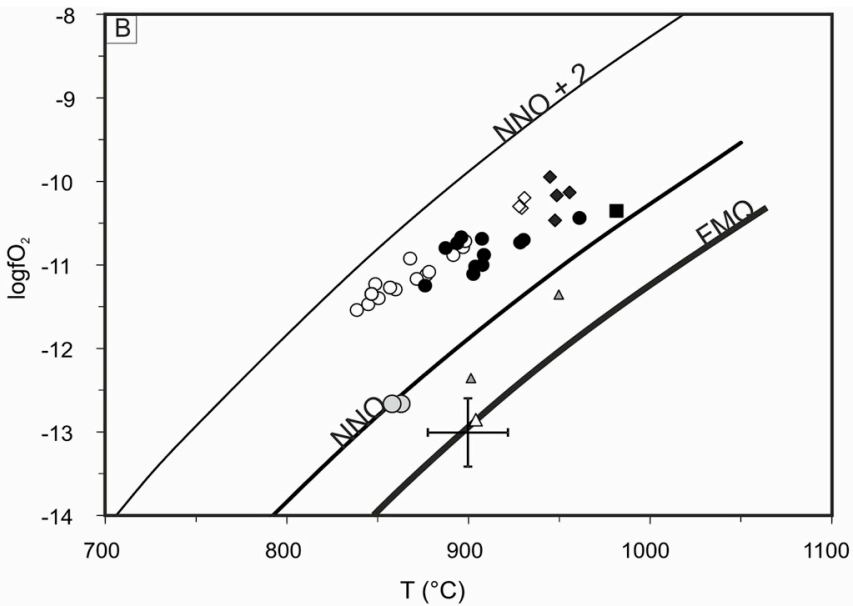

- G2-63 (center)

Amp-bearing volcanic rocks

O $2-63$ (rims)

O $2-63$ (single crystal)

$$
\begin{array}{ll}
\Delta \mathrm{T} 1 & \Delta \mathrm{T} 0 \\
* \mathrm{G} 2-63(\mathrm{EDS}) & +\mathrm{JZ6}-4(\mathrm{EDS}) \\
\text { - G3-134 } &
\end{array}
$$

\section{Cpx-bearing volcanic rock}

- G3-157 (center)

$\diamond \mathrm{G} 3-157$ (rim)

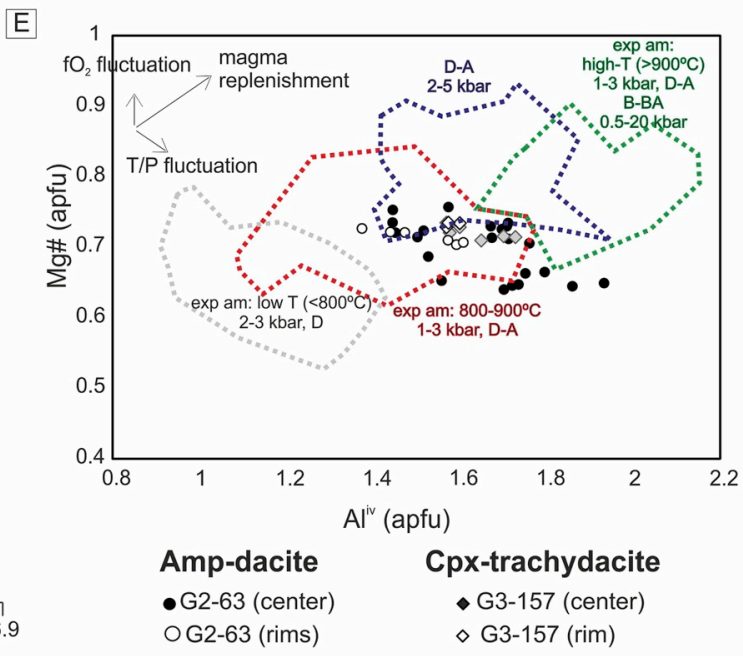

Fig. 10. Liquid compositions in equilibrium with amphibole and oxygen fugacities estimated from amphibole data and temperature data calculated from the

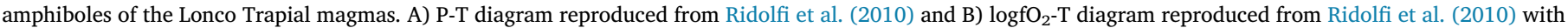
the spreadsheet Amp-TB. xls of Ridolfi et al. (2010). Error bars represent that the maximum $\operatorname{logfO}_{2}$ errors are $0.4 \log$ unit and the expected $\sigma\left(22{ }^{\circ} \mathrm{C}\right)$. In $\left.\mathrm{B}\right)$ the graph shows the NNO and NNO +2 curves from O'Neill and Pownceby (1993). C) Diagram of Anderson and Smith (1995) showing the effect of oxygen fugacity in hornblende compositions $\left(\mathrm{Fe}_{\mathrm{T}} /\left(\mathrm{Fe}_{\mathrm{T}}+\mathrm{Mg}\right)\right.$ vs. $\left.\mathrm{Al}^{\mathrm{iv}}\right)$. D) Compositional variation of the amphiboles (silica content) with the temperature calculated with Putirka (2016) geothermometer. Silica content calculated with the total Fe as FeO total (Excel spreadsheet of Putirka, 2016). E) Plot of Al ${ }^{\mathrm{iv}}$ vs. Mg\# showing the correlation of the Lonco Trapial magmas with experimental amphiboles crystallized under different conditions (fields taken from Kiss et al., 2014 and references therein).

et al., 2006; Kiss et al., 2014; Zhang et al., 2017). It should be taken into account, besides, that amphiboles with reaction textures provide constraints on the earlier (pre-breakdown) equilibrium conditions (Ridolfi et al., 2008).

Magma storage temperatures were calculated with different geothermometers that are based on amphibole-plagioclase compositions (Holland and Blundy, 1994, expression B), amphibole compositions (Ridolfi et al., 2010; Ridolfi and Renzulli, 2012; Putirka, 2016), melt compositions (Molina et al., 2015; Putirka, 2016), or on zircon (Harrison and Watson, 1983; Boehnke et al., 2013) and apatite compositions (Harrison and Watson, 1984). Individual results are presented in Tables 1-3 in the Appendix, and a summary is presented in Table 3.

Temperatures calculated with the calibrations of Ridolfi et al. (2010), Ridolfi and Renzulli (2012) and Putirka (2016) (Fig. 10d) broadly agree (Table 3). Temperatures obtained with the calibration of Putirka (2016) shown in Fig. 10d are considered the most accurate 
Table 2

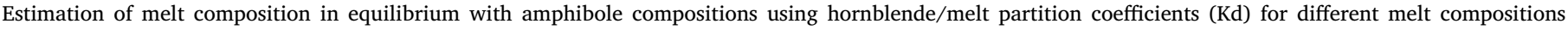
(andesite, dacite and rhyolite). References: 1: Sisson (1994), 2: Bacon and Druitt (1988), 3: Nagasawa and Schneltzer (1971) and 4: Matsui et al. (1977).

\begin{tabular}{|c|c|c|c|c|c|c|c|c|c|c|c|c|c|c|c|c|c|c|c|c|}
\hline \multirow{2}{*}{$\begin{array}{l}\text { Element/ratio } \\
\text { Melt/material }\end{array}$} & \multicolumn{3}{|c|}{$\mathrm{La}$} & \multicolumn{3}{|c|}{$\mathrm{Yb}$} & \multicolumn{3}{|c|}{$[\mathrm{La} / \mathrm{Yb}]_{\mathrm{n}}$ melt } & \multirow{2}{*}{\begin{tabular}{|l|}
{$[\mathrm{La} / \mathrm{Yb}]_{\mathrm{n}}$} \\
whole \\
rock
\end{tabular}} & \multicolumn{2}{|c|}{$\mathrm{Sm}$} & \multicolumn{3}{|c|}{$\mathrm{Eu}$} & \multicolumn{2}{|c|}{$\mathrm{Gd}$} & \multicolumn{2}{|c|}{$\mathrm{Eu} / \mathrm{Eu}^{*}$ melt } & \multirow{2}{*}{\begin{tabular}{|l}
$\mathrm{Eu} / \mathrm{Eu}^{*}$ \\
whole \\
rock
\end{tabular}} \\
\hline & andesite & dacite & rhyolite & andesite & dacite & rhyolite & andesitic & dacitic & rhyolitic & & andesite & dacite & andesite & dacite & rhyolite & andesite & dacite & andesitic & dacitic & \\
\hline $\mathrm{Kd}$ & 0.48 & 0.26 & 1.92 & 2.73 & 1.31 & 5.5 & & & & & 3.85 & 2.38 & 1.9 & 5.9 & 3.2 & 1.72 & 2 & & & \\
\hline Reference & \multicolumn{3}{|c|}{1} & \multicolumn{3}{|c|}{1} & & & & & \multicolumn{2}{|l|}{1} & 2 & 3 & 2 & 4 & 3 & & & \\
\hline T1-1 & 3.31 & 3.31 & 3.31 & 2.19 & 2.19 & 2.19 & & & & & 5.11 & 5.11 & 1.43 & 1.43 & 1.43 & 5.75 & 5.75 & & & \\
\hline T1-2 & 8.76 & 8.76 & 8.76 & 4.56 & 4.56 & 4.56 & & & & & 18.33 & 18.33 & 3.93 & 3.93 & 3.93 & 16.08 & 16.08 & & & \\
\hline T1-average & 6.04 & 6.04 & 6.04 & 3.38 & 3.38 & 3.38 & & & & & 11.72 & \begin{tabular}{|l}
1.72 \\
\end{tabular} & 2.68 & 2.68 & 2.68 & 10.92 & 10.92 & & & \\
\hline Cmelt (T1) & 12.57 & 23.21 & 3.14 & 1.24 & 2.58 & 0.61 & 6.91 & 6.12 & 3.48 & 11.20 & 3.04 & 4.92 & 1.41 & 0.45 & 0.84 & 6.35 & 5.46 & 0.98 & 0.27 & 0.91 \\
\hline T0 & 8.68 & \begin{tabular}{|l|}
8.68 \\
\end{tabular} & 8.68 & 6.11 & 6.11 & 6.11 & & & & & 7.20 & 7.20 & 1.98 & 1.98 & 1.98 & 7.74 & 7.74 & & & \\
\hline Cmelt (T0) & 18.08 & 33.38 & 4.52 & 2.24 & 4.66 & 1.11 & 5.49 & 4.86 & 2.76 & 12.80 & 1.87 & 3.03 & 1.04 & 0.34 & 0.62 & 4.50 & 3.87 & 1.10 & 0.30 & 0.96 \\
\hline G2-63-1 & 10.91 & 10.91 & 10.91 & 5.10 & 5.10 & 5.10 & & & & & 15.55 & 15.55 & 3.51 & 3.51 & 3.51 & 14.37 & 14.37 & & & \\
\hline G2-63-2 & 13.47 & 13.47 & 13.47 & 4.00 & 4.00 & 4.00 & & & & & 10.35 & 10.35 & 2.60 & 2.60 & 2.60 & 9.60 & 9.60 & & & \\
\hline $\begin{array}{l}\text { G2-63- } \\
\text { average }\end{array}$ & 12.19 & 12.19 & 12.19 & 4.55 & 4.55 & 4.55 & & & & & 12.95 & 12.95 & 3.06 & 3.06 & 3.06 & 11.99 & 11.99 & & & \\
\hline $\begin{array}{c}\text { Cmelt } \\
\text { (G2-63) }\end{array}$ & 25.40 & 46.88 & 6.35 & 1.67 & 3.47 & 0.83 & 10.35 & 9.17 & 5.21 & 12.10 & 3.36 & 5.44 & 1.61 & 0.52 & 0.95 & 6.97 & 5.99 & 1.01 & 0.28 & 1.08 \\
\hline G3-134-amp & 6.64 & 6.64 & 6.64 & 1.67 & 1.67 & 1.67 & & & & & 8.10 & 8.10 & 2.33 & 2.33 & 2.33 & 7.82 & 7.82 & & & \\
\hline $\begin{array}{c}\text { Cmelt } \\
\text { (G3-134) }\end{array}$ & 13.83 & 25.54 & 3.46 & 0.61 & 1.27 & 0.30 & 15.36 & 13.61 & 7.74 & 13.80 & 2.10 & 3.40 & 1.23 & 0.39 & 0.73 & 4.55 & 3.91 & 1.21 & 0.33 & 0.89 \\
\hline
\end{tabular}

because this geothermometer uses the most complete dataset of experimental amphiboles. In all samples, these temperatures are between $\sim 820$ and $970{ }^{\circ} \mathrm{C}$ (Table 3), in agreement with amphiboles crystallized from andesitic to dacitic melts not in equilibrium with quartz (Ridolfi et al., 2010). Taking the three temperature calibrations into account, amphibole cores in sample G2-63 crystallized at $\sim 869-916^{\circ} \mathrm{C}$ with an average of $895^{\circ} \mathrm{C}$, whereas amphibole rims crystallized at $\sim 825-865^{\circ} \mathrm{C}$ with an average of $850^{\circ} \mathrm{C}$ (Table 3). The higher temperatures in the amphibole microphenocrysts of the clinopyroxene-bearing volcanic rocks (cores $\sim 960-1017^{\circ} \mathrm{C}$, and rims $\sim 929-1000^{\circ} \mathrm{C}$; Table 3 ) are due to higher $\mathrm{Ti}$ contents, in agreement with their more primitive and alkaline character (Molina et al., 2009).

The geothermometer based on amphibole-plagioclase equilibrium of Holland and Blundy (1994) was applied for samples G2-63 and G3157. Temperatures for amphibole cores and plagioclase cores for sample G2-63 are around $857^{\circ} \mathrm{C}$ and around $948^{\circ} \mathrm{C}$ for sample G3-157 (Table 3). These temperatures generally coincident with the amphiboleonly temperatures of Ridolfi et al. (2010), Ridolfi and Renzulli (2012) and Putirka (2016) geothermometers (Table 3), although they are a bit lower probably due to calibration problems (Blundy and Cashman, 2008).

Liquid-only temperatures for amphibole-saturated magmas of Molina et al. (2015) and Putirka (2016) are slightly higher than the temperatures calculated from amphibole phenocrysts. The composition of the liquid was estimated by the whole-rock composition. The obtained temperatures range from 960 to $1052{ }^{\circ} \mathrm{C}$ (Table 3), they are compatible with the stability field of amphibole in subalkaline liquids (see Fig. 14 in Molina et al., 2009 and Fig. 9 in Kiss et al., 2014). These results are concordant with amphibole-saturated parental melts. These temperatures are higher than the temperatures estimated from amphibole-only geothermometers, even higher than the temperatures estimated from the cores of the amphibole phenocrysts (Table 3). The reason for this would be that these liquid-only temperatures may be representative of a liquid saturated in amphibole, but this amphibole would not be the one forming the phenocrysts, which would be in equilibrium, instead, with a liquid of a more evolved composition.

Apatite saturation temperatures calculated for the amphibolebearing volcanic rocks are close to the liquid-only temperatures, suggesting apatite saturation in parental melts consistent with the presence of apatite crystals in the groundmass. The apatite saturation temperatures in the most primitive sample (clinopyroxene-bearing trachydacite G3-157) are significatively lower than the amphibole-only and the liquid-only temperatures. The low zircon saturation temperatures close to the solidus in amphibole-bearing as well as in clinopyroxene-bearing volcanic rocks suggest that the magma was not saturated in zircon (Table 3).

The composition of the amphiboles is compared with amphiboles experimentally crystallized at different temperature and pressure conditions in Fig. 10e (Kiss et al., 2014). The amphiboles of Lonco Trapial generally agree with the field of experimental amphiboles crystallized between 800 and $900^{\circ} \mathrm{C}$, which is consistent with temperatures predicted by the Putirka (2016) and Ridolfi et al. (2010) geothermometers (Table 3).

We estimated crystallization pressures using the amphibole-only geobarometers of Ridolfi et al. (2010) and Ridolfi and Renzulli (2012) (equation 1d), which is considered the most accurate (Molina et al., 2015) and the amphibole-plagioclase barometer of Molina et al. (2015). Only the amphibole-bearing dacite G2-63 was suitable for the geobarometer of Molina et al. (2015) because the amphiboles of the clinopyroxene-bearing trachydacite G3-157 were rejected because they had $\mathrm{Al}^{\mathrm{vi}}<0.05$. Pressures calculated with the Molina et al. (2015) geobarometer range from 8 to $5 \mathrm{kbar}$ (average $7.6 \mathrm{kbar}$ at T1, Table 3) for cores and from 2 to $4 \mathrm{kbar}$ (average $3.5 \mathrm{kbar}$ at T1, Table 3) for rims. The amphibole-plagioclase barometer of Anderson and Smith (1995) was used with the temperature calculation of Holland and Blundy (1994) considering amphibole and plagioclase core compositions of sample G2-63. Results show pressures around $6.29 \mathrm{kbar}$, which are mostly within the range of core pressures obtained with the Molina et al. (2015) amphibole-plagioclase barometer.

For sample G2-63, pressures calculated with the calibrations of Ridolfi et al. (2010) are around $7.4 \mathrm{kbar}$ for the cores and around $2.2 \pm 0.4 \mathrm{kbar}$ for the rims (Table 3). For the same sample, pressures calculated with the calculation of Ridolfi and Renzulli (2012) are around $1.65 \pm 2.5 \mathrm{kbar}$ for the rims (Table 3). Amphibole-plagioclase equilibrium pressures are around $6.29 \mathrm{kbar}$ using the iteration geobarometer of Anderson and Smith (1995) with core compositions in both minerals. In addition, we performed the amphibole-plagioclase geobarometric calculation of Molina et al. (2015), and their pressures were comprised within 8 and $5 \mathrm{kbar}$ for the cores and between 2 and for kbar for the rims (Table 3). The general consistency of the pressures 


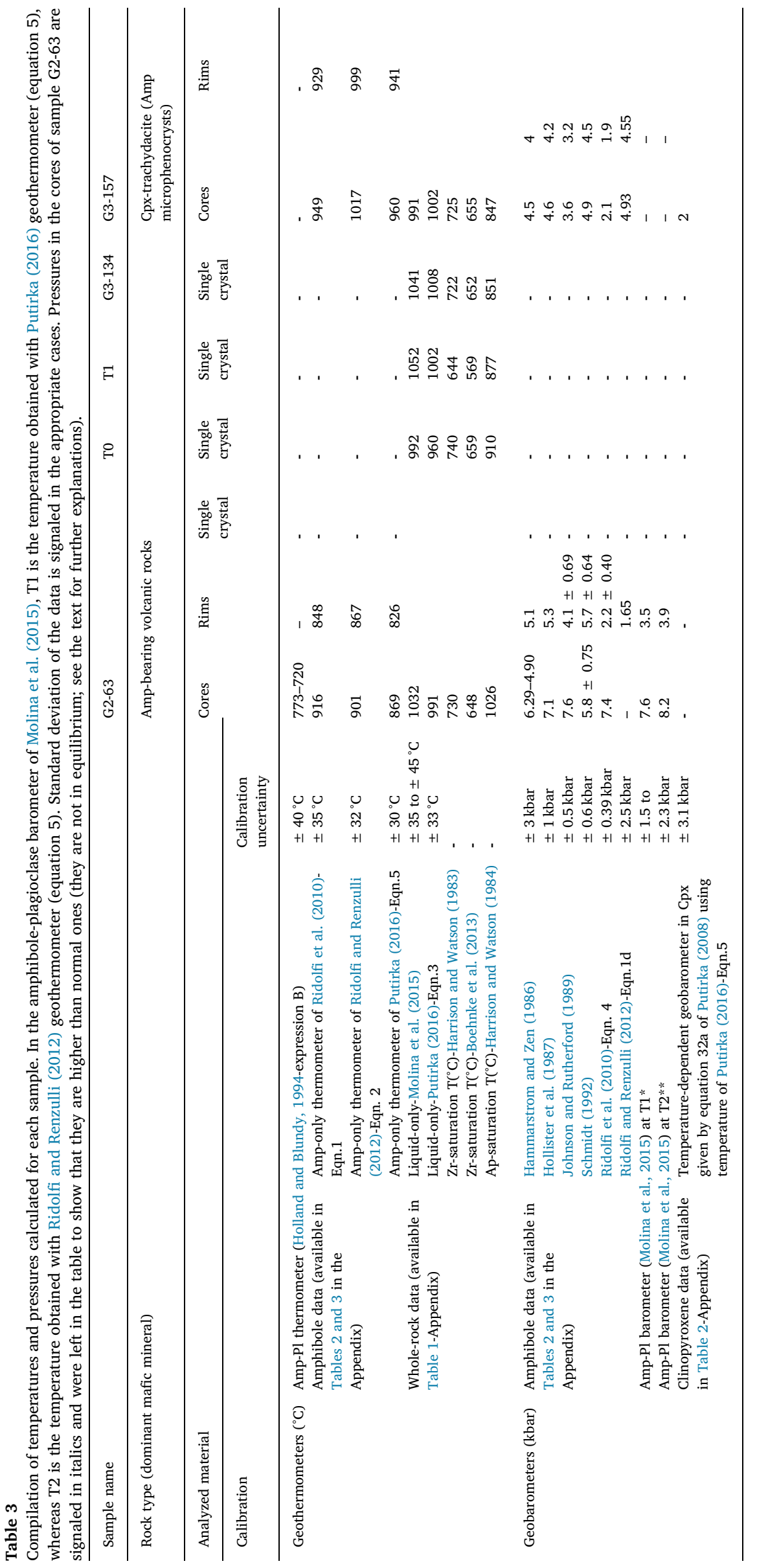




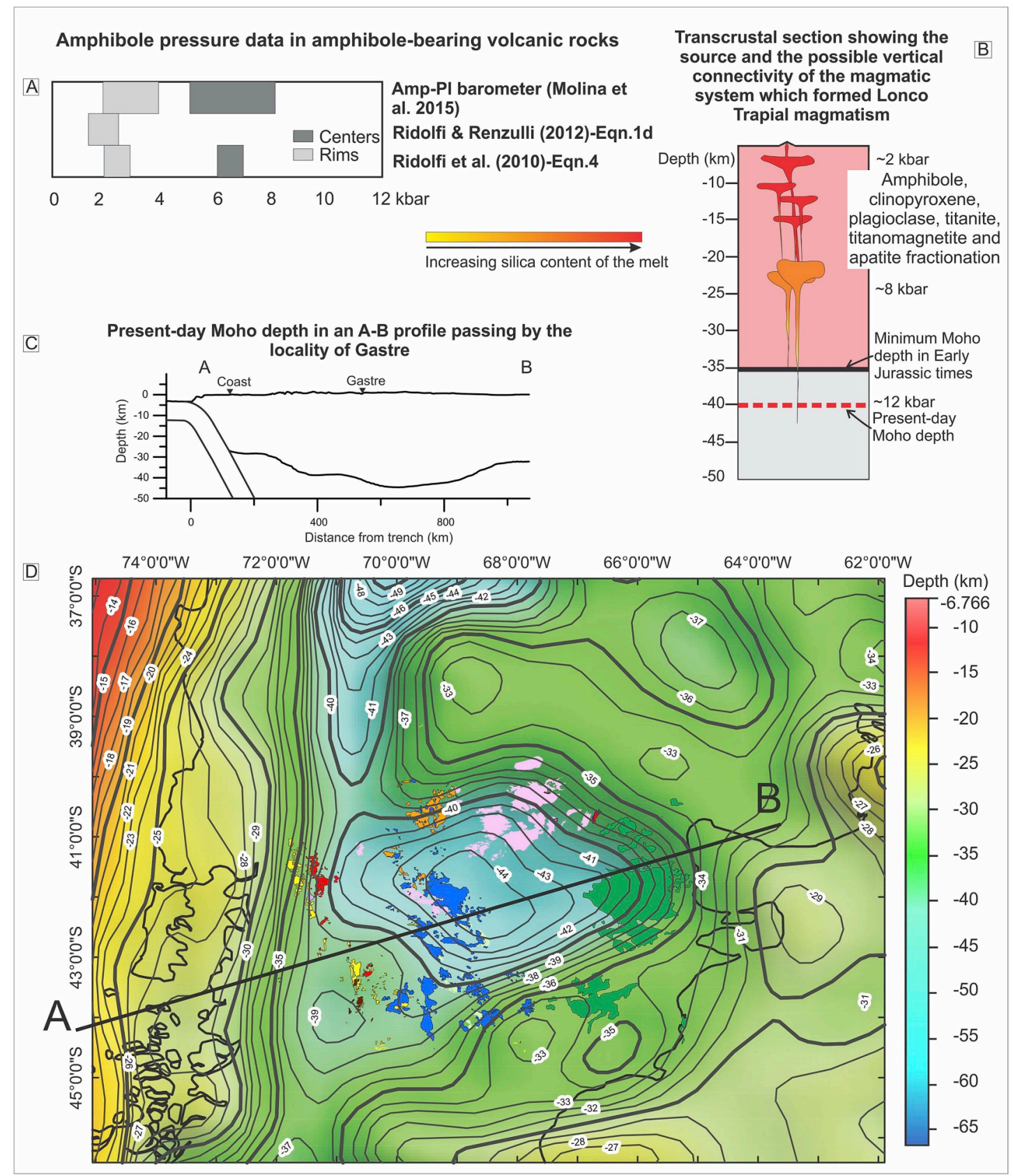

Fig. 11. Source of the Lonco Trapial andesitic magmas. A) Comparison of amphibole pressure data in the amphibole-bearing volcanic rocks obtained with the different calibrations. B) Interpretation of the magmatic system of the Lonco Trapial Formation bringing together all the available information. C), D) Current Moho depth estimated from inversion of gravimetric data (Reguzzoni and Sampietro, 2015). The lithological units are the same as in Fig. 1a.

calculated for the cores and rims of the amphibole-bearing dacite G2-63 suggests that equilibrium conditions were reached during the crystallization history of the amphibole-bearing volcanic rocks.

In turn, for the clinopyroxene-bearing trachydacite G3-157, the temperature-dependent geobarometer of Putirka (2008; equation 32a) was employed, as it contains clinopyroxene phenocrysts and small amphiboles microphenocrysts. For this calculation, the temperatures obtained from cores of amphiboles based on the pressure-independent geothermometer of Putirka (2016) were used. As a result, the calculated pressures are around $2 \mathrm{kbar}$ (Table 3). The amphibole-plagioclase barometer of Anderson and Smith (1995) was also used in this sample, considering amphibole and plagioclase core compositions, and using the temperature calculation of Holland and Blundy (1994). A pressure of $2.51 \mathrm{kbar}$ was therefore obtained (Table 3). The amphibole-only geobarometer of Ridolfi et al. (2010) also gave a pressure around $2 \mathrm{kbar}$ for cores and rims (Table 3 ). In this sample there is also a consistency in the obtained pressures for cores and rims (with the clinopyroxene-only geobarometer of Putirka (2008), with the geobarometer of Ridolfi et al. 
(2010) and with the geobarometer of Anderson and Smith (1995), Table 3). In addition, there is a consistency within the pressures of cores and rims of sample G3-157 with the pressures obtained for the rims of sample G2-63 (within error). This consistency may further suggest equilibrium conditions during the crystallization of the clinopyroxenebearing volcanic rocks.

It must be observed, though, that in sample G3-157, higher pressures around 3-4 kbar are obtained with the equation 1. d of Ridolfi and Renzulli (2012) (Table 3) and with the Al-in-hornblende geobarometers. However, as the latter geobarometers tend to overestimate the pressures, especially in quartz-undersaturated magmas because amphibole tends to have lower $\mathrm{Si}$ content thus increasing $\mathrm{Al}^{\mathrm{IV}}$ occupancy (see Hammarstrom and Zen, 1986), it is considered that the real pressures for this sample should be around $2 \mathrm{kbar}$.

\subsection{General tectonic interpretation of thermobarometric and geochemical data}

Crystallization temperatures for the amphibole- and clinopyroxenebearing volcanic rocks of the Lonco Trapial Formation are constrained around 826 and $1017^{\circ} \mathrm{C}$ (Table 3). These temperatures are typical for magmas of intermediate composition (e.g. Rutherford and Devine, 2008), and the temperatures are below the maximum stability of amphibole in primitive magmas (around $1050^{\circ} \mathrm{C}$; Pichavant et al., 2002; Grove et al., 2003; Barclay and Carmichael, 2004; Adam et al., 2007; Krawczynski et al., 2012; Simakin et al., 2012).

Pressures estimated for the amphibole rims in the amphibolebearing volcanic rocks are comprised between 2 and $4 \mathrm{kbar}$. In addition, pressure estimations for the amphibole microphenocrysts (cores and rims) in the clinopyroxene-bearing volcanic rocks are around $2 \mathrm{kbar}$ (Table 3). These amphiboles would have crystallized in equilibrium with plagioclase within the upper crust (between 7 and $15 \mathrm{~km}$, approximately, using a geothermal gradient of $3.7 \mathrm{~km} / \mathrm{kbar}$ ). In the amphibole-bearing volcanic rocks, the cores of the amphiboles would record a previous history, and they would have crystallized at a different pressure around $\sim 7-8 \mathrm{kbar}$ which would correspond to $\sim 22-26 \mathrm{~km}$.

Pressures around 2-8 kbar in the amphibole cores and rims of the amphibole-bearing volcanic rocks are consistent with whole-rock geochemical data, as the host-rock has no fractionated heavy REE $\left(\mathrm{Yb}<2.4,[\mathrm{La} / \mathrm{Yb}]_{\mathrm{N}}\right.$ between 7 and 14, Table 1-Appendix), and the decreasing $\mathrm{Dy} / \mathrm{Yb}$ trend with silica is consistent with amphibole and/or clinopyroxene (and no garnet) at the source or as a fractionating phase (Fig. 5b and c).

The different pressures calculated for the cores and rims of the amphibole-bearing volcanic rocks would suggest a polybaric history of crystallization along a transcrustal magmatic reservoir (see review of transcrustal magmatic systems in Cashman et al., 2017) for Lonco Trapial andesites, dacites and trachydacites (Fig. 11b). Sr, Nd and $\mathrm{Pb}$ isotopic data of Bouhier et al. (2017) support crustal and mantle contribution to the Jurassic magmas of Lonco Trapial Formation. The andesitic to dacitic magmas, which bear low $\mathrm{Cr}$ and $\mathrm{Ni}$ contents must have evolved from a mantle source. In summary, the calc-alkaline signature of Lonco Trapial Formation andesites, dacites and trachydacites could have been obtained either from a mantle source previously metasomatised by earlier subduction processes (Late Paleozoic and Late Triassic; Proserpio, 1978; Rapela and Pankhurst, 1992; Pankhurst et al., 2000) or, alternatively, by crustal contamination. However, the role of crustal contamination should have been strong, as is evidenced by the $\mathrm{Nb} / \mathrm{Ta}$ ratios and by the isotopic data of Bouhier et al. (2017).

The Lonco Trapial lavas constitute the basement of the Early Jurassic Cañadón Asfalto basin, as it overlies the syn-rift deposits of the Las Leoneras Formation (Cúneo et al., 2013, Fig. 1a). As no marine ingressions were registered on this basin, the crust should not have been thinner than $35 \mathrm{~km}$ (i.e. Ramos et al., 2004). It is therefore inferred that the Early Jurassic rifting could have developed on a previously thickened crust (around 50-60 km), probably inherited from the Late Paleozoic Gondwanic Orogenic Cycle (i.e. Pankhurst et al., 2000). The crust would have thinned in the Early Jurassic (during V1 volcanic event) to $\sim 35 \mathrm{~km}$. Therefore, the obtained pressures are coherent with regional geological constraints. The present-day Moho depth in Gastre is around $44 \mathrm{~km}$, as is inferred by the crustal model GEMMA obtained from inversion of gravimetric data (Reguzzoni and Sampietro, 2015, Fig. 11c-d). The greater depth found today would have been reached by thermal subsidence after the rifting period (by deposition of younger material in the Gastre basin, see for example Bilmes et al. 2013) and during Mid-Cretaceous upper plate contraction (Zaffarana et al., 2018; Echaurren et al., 2016, 2017).

\section{Conclusions}

The Early Jurassic volcanic rocks of the Lonco Trapial Formation erupted coevally with widespread extension during the early stages of Gondwana break-up. The andesites, dacites and trachydacites can be divided into two main types: amphibole-bearing and clinopyroxenebearing (volcanic rocks with either amphibole or clinopyroxene as the main mafic mineral), though amphibole is the most common mafic phase. They represent calc-alkaline magmas; nevertheless, a mild alkaline affinity arises from some whole-rock trace elements content and from mineral chemistry (amphibole, clinopyroxene and titanomagnetite compositions). The calc-alkaline signature of the Lonco Trapial magmas can reflect a mantle source metasomatised by a previous subduction processes and/or a significant assimilation of crustal rocks (the latter being particularly supported by the isotopic data from Bouhier et al., 2017).

Trace element data in amphiboles together with whole-rock trace element data suggest that the magmatic evolution of the Lonco Trapial magmas was governed by a combination of amphibole, clinopyroxene, plagioclase, titanite, titanomagnetite and apatite fractionation. A melt of andesitic to dacitic composition was inferred to be in equilibrium with the amphibole cores, whereas a melt of dacitic to rhyolitic composition was inferred to be in equilibrium amphibole rims. Amphibole and apatite crystallization would have predominantly controlled the fractionation of the middle REE.

The cores of the amphiboles in the amphibole-bearing volcanic rocks of the Lonco Trapial Formation crystallized at a temperature ranging from 869 to $916^{\circ} \mathrm{C}$, and the rims at a temperature ranging from 826 to $867{ }^{\circ} \mathrm{C}$ and at predominantly shallow to intermediate depths (2-8 kbar, $\sim 7-26 \mathrm{~km})$. The clinopyroxene-bearing volcanic rocks would have crystallized at higher temperatures, between 929 and $1017^{\circ} \mathrm{C}$, consistent with their more primitive character. Oxygen fugacity conditions were high, in concordance with presence of titanomagnetite in some samples. The crystallization pressures of Lonco Trapial magmas agree with regional geological observations which suggest that the Moho depth in the Gastre area should have been more than $35 \mathrm{~km}$ in Early Jurassic times.

\section{Acknowledgements}

This work was financed with PIP CONICET 112-200901-00766, PICT 2014-1394 and with the Torandes Project (CGL 2012-38396-C03) from the Plan de I + D + i Español with UE-FEDER funds. We thank Gerhard Wörner for the analyses of the amphiboles by ICP-MS at the GZG, University of Göttingen (Germany). We thank Andrés Cuesta and Miguel Ángel Fernández for their help in the analysis by electron microprobe at the Technical-Scientific services of Oviedo University (Spain). We greatly thank José Francisco Molina, Michel Grégoire and Kelly Russell for their great help with the correction of an earlier version of this manuscript. We are especially grateful to Romina Sulla for reviewing the English text. 


\section{Appendix}
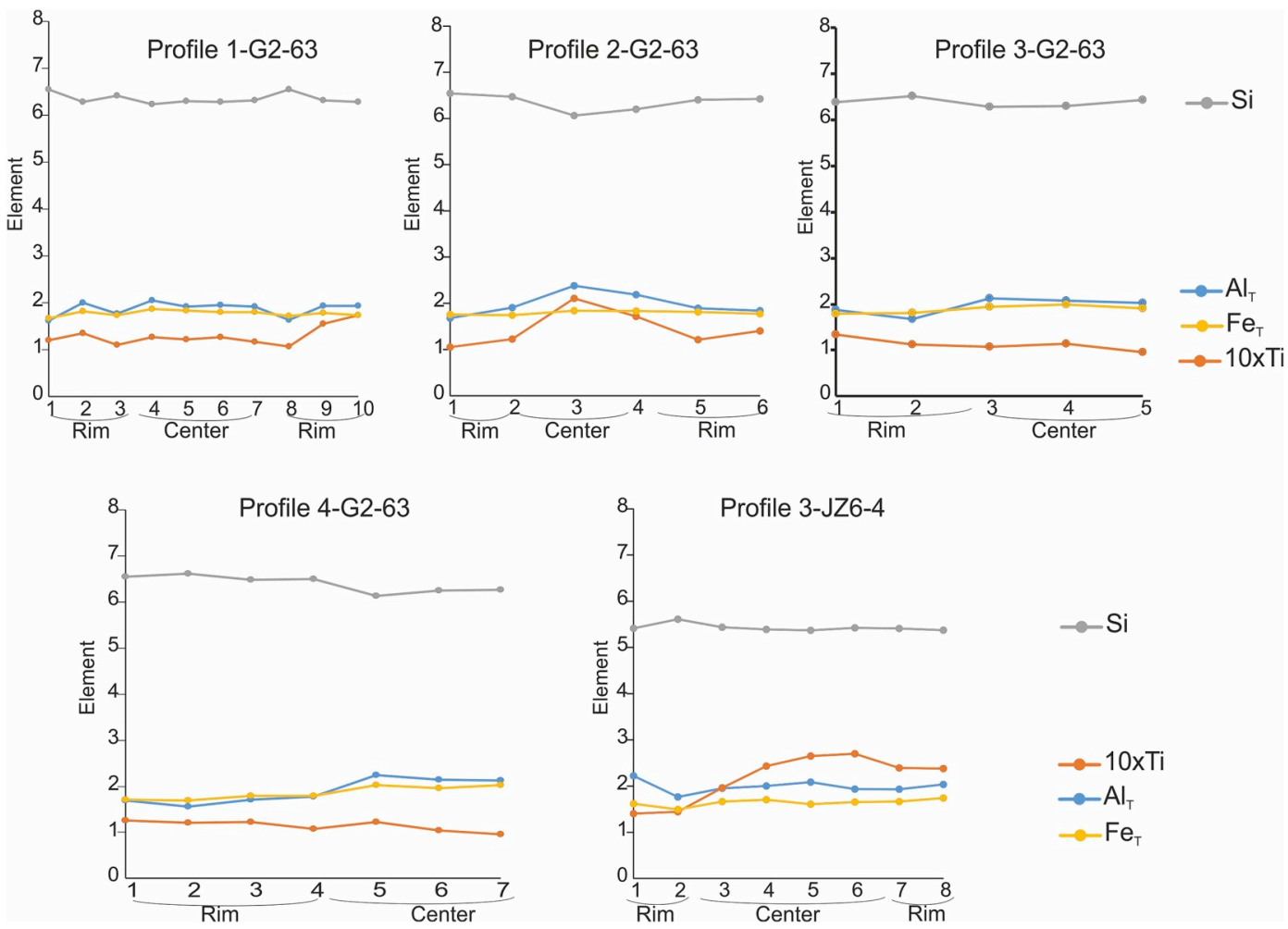

Fig. 1. Appendix: Scans across zoned amphibole from samples G2-63 (with electron microprobe) and JZ6-4 (with EDS). In sample G2-63: profile 1 and 2:scans $0.6 \mathrm{~mm}$ long, profiles 3 and 4: scans $0.4 \mathrm{~mm}$ long. In sample JZ6-4 the scan measures $0.6 \mathrm{~mm}$ long. 

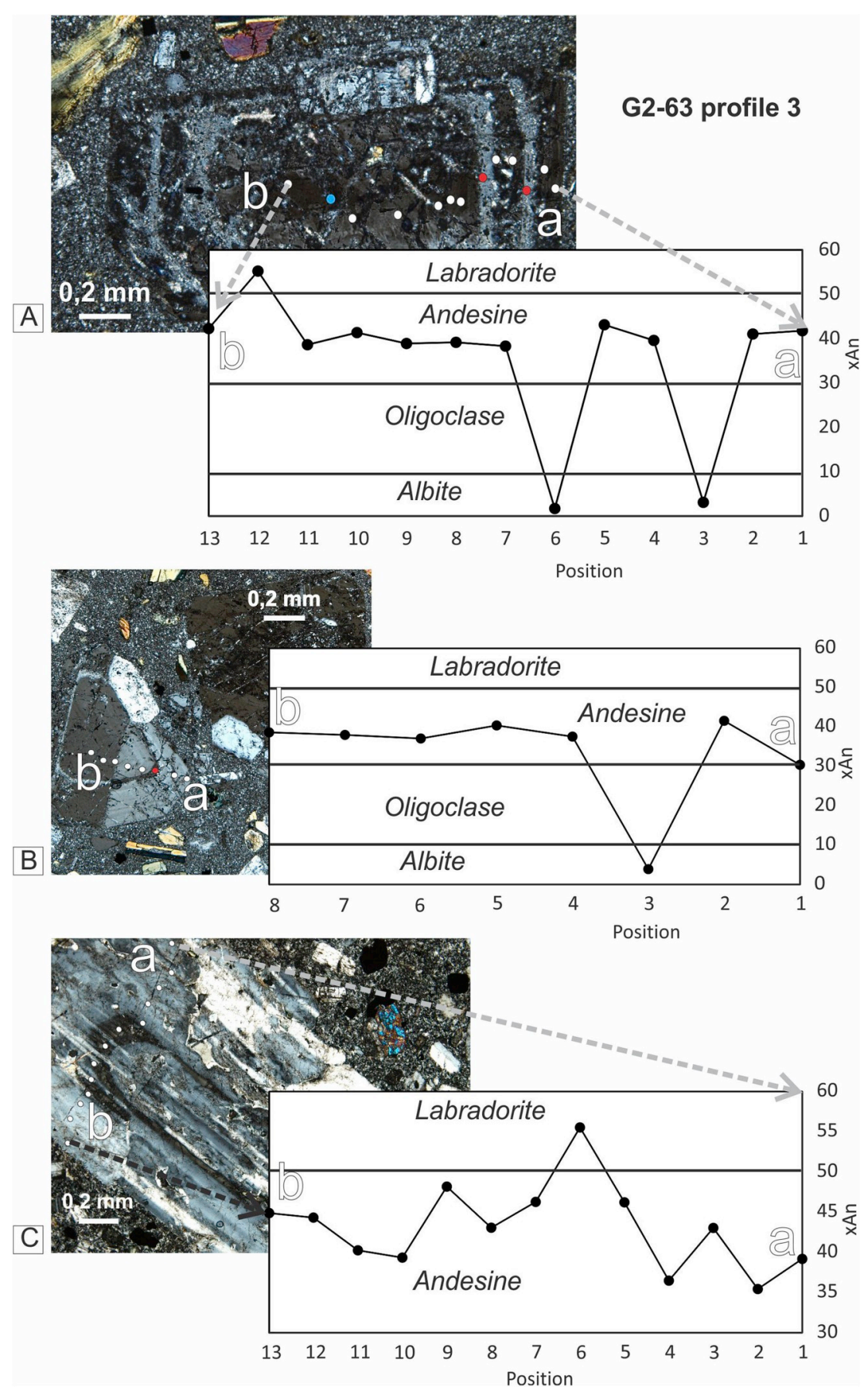

Fig. 2. Appendix: Plagioclase zoning profiles of the Lonco Trapial volcanics. A), B) Profiles performed with electron microprobe in sample G2-63. Red points mark the position of the albitic rings. C) Profile performed with electron microprobe in sample G3-157.2 
Table 1-Appendix

Whole-rock geochemical data presented on anhydrous basis. CA/TH index is after Hora et al. (2009), Dy/Yb* is after Davidson et al. (2013). Major oxides are expressed on an anhydrous basis. The normalizations are performed with respect to the chondrite of McDonough and Sun (1995). Temperature calculations performed with different geothermometers are added (liquid-only from Molina et al., 2015; Zr-saturation temperature from Harrison and Watson, 1983 and from Boehnke et al., 2013; apatite-saturation temperature from Harrison and Watson, 1984).

\begin{tabular}{|c|c|c|c|c|c|}
\hline \multirow[t]{2}{*}{ outcrop } & T0 & $\mathrm{T} 1$ & G2-63 & G3-134 & G3-157 \\
\hline & $\begin{array}{l}\text { andesitic } \\
\text { lava }\end{array}$ & andesitic lava & $\begin{array}{l}\text { andesitic } \\
\text { porphyry }\end{array}$ & andesitic dike & andesitic lava \\
\hline Main rock type & Amp-dacite & Amp-trachydacite & Amp-dacite & Amp-andesite & Cpx-trachydacite \\
\hline Phenocrysts and microphenocrysts & $\mathrm{Pl}+\mathrm{Amp}$ & $\mathrm{Pl}+\mathrm{Amp}+\mathrm{Cpx}+\mathrm{Bt}$ & $\mathrm{Pl}+\mathrm{Amp}+\mathrm{Bt}$ & $\begin{array}{l}\mathrm{Pl}+\mathrm{Amp}(\mathrm{Cpx} \text { cores in } \\
\text { Amp) }\end{array}$ & $\begin{array}{l}\mathrm{Pl}+\mathrm{Cpx} \text { (Amp } \\
\text { microphenocrysts) }\end{array}$ \\
\hline Accesory minerals & \multicolumn{5}{|c|}{ Titanomagnetite, apatite, titanite } \\
\hline $\mathrm{SiO}_{2}$ & 63.17 & 61.60 & 61.79 & 58.57 & 59.72 \\
\hline $\mathrm{TiO}_{2}$ & 0.53 & 0.56 & 0.56 & 0.96 & 1.46 \\
\hline $\mathrm{Al} 2 \mathrm{O} 3$ & 16.85 & 17.33 & 17.83 & 16.12 & 15.56 \\
\hline $\mathrm{FeO}_{\mathrm{t}}$ & 5.31 & 4.98 & 4.80 & 6.50 & 6.78 \\
\hline $\mathrm{MnO}$ & 0.08 & 0.09 & 0.09 & 0.07 & 0.17 \\
\hline $\mathrm{MgO}$ & 2.51 & 3.78 & 3.50 & 4.97 & 3.04 \\
\hline $\mathrm{CaO}$ & 4.97 & 4.16 & 4.96 & 6.29 & 5.93 \\
\hline $\mathrm{Na}_{2} \mathrm{O}$ & 4.60 & 5.22 & 4.68 & 3.86 & 5.27 \\
\hline $\mathrm{K}_{2} \mathrm{O}$ & 1.83 & 2.10 & 1.61 & 2.31 & 1.47 \\
\hline $\mathrm{P}_{2} \mathrm{O}_{5}$ & 0.14 & 0.17 & 0.19 & 0.35 & 0.59 \\
\hline LOI & 1.99 & 2.31 & 2.20 & 1.90 & 2.10 \\
\hline Total & 100.00 & 100.00 & 100.00 & 100.00 & 100.00 \\
\hline $\mathrm{U}$ & 1.10 & 0.70 & 0.42 & 1.30 & 0.77 \\
\hline Th & 3.80 & 2.50 & 1.90 & 4.00 & 4.40 \\
\hline $\mathrm{Zr}$ & 115.00 & 111.00 & 128.00 & 292.00 & 266.00 \\
\hline $\mathrm{Hf}$ & 2.70 & 2.90 & 5.10 & 12.40 & 12.40 \\
\hline $\mathrm{Ta}$ & 0.60 & 0.50 & 0.40 & 1.80 & 0.60 \\
\hline $\mathrm{Nb}$ & 5.00 & 4.00 & 4.00 & 7.00 & 6.00 \\
\hline Y & 10.00 & 10.00 & 9.10 & 14.70 & 25.10 \\
\hline $\mathrm{Ba}$ & 766.00 & 1253.00 & 982.00 & 1000.00 & 970.00 \\
\hline $\mathrm{Sr}$ & 658.00 & 602.00 & 721.40 & 771.10 & 594.80 \\
\hline Cs & $<0.5$ & 3.40 & & & \\
\hline $\mathrm{Rb}$ & 37.00 & 38.00 & 34.40 & 78.90 & 29.20 \\
\hline $\mathrm{Cr}$ & 100.00 & 110.00 & 61.00 & 84.00 & 8.00 \\
\hline $\mathrm{Ni}$ & 30.00 & 30.00 & 26.00 & 80.00 & 5.00 \\
\hline $\mathrm{La}$ & 20.70 & 18.10 & 16.00 & 30.40 & 26.20 \\
\hline $\mathrm{Ce}$ & 40.20 & 38.20 & 30.80 & 85.10 & 78.50 \\
\hline $\operatorname{Pr}$ & 4.38 & 4.50 & 3.45 & 9.72 & 9.14 \\
\hline $\mathrm{Nd}$ & 16.10 & 17.80 & 12.70 & 32.30 & 30.40 \\
\hline $\mathrm{Sm}$ & 3.20 & 3.60 & 2.30 & 7.40 & 7.40 \\
\hline $\mathrm{Eu}$ & 0.93 & 1.00 & 0.77 & 1.91 & 2.04 \\
\hline $\mathrm{Gd}$ & 2.70 & 3.10 & 2.05 & 5.68 & 6.91 \\
\hline $\mathrm{Tb}$ & 0.40 & 0.40 & 0.33 & 0.79 & 0.93 \\
\hline Dy & 2.10 & 2.40 & 1.75 & 3.91 & 5.57 \\
\hline Ho & 0.40 & 0.40 & 0.33 & 0.66 & 1.08 \\
\hline Er & 1.20 & 1.30 & 0.81 & 1.65 & 2.85 \\
\hline $\mathrm{Tm}$ & 0.17 & 0.18 & 0.13 & 0.27 & 0.39 \\
\hline $\mathrm{Yb}$ & 1.10 & 1.10 & 0.90 & 1.50 & 2.40 \\
\hline $\mathrm{Lu}$ & 0.18 & 0.19 & 0.15 & 0.23 & 0.39 \\
\hline $\mathrm{Pb}$ & 18.00 & 10.00 & 9.00 & 19.00 & 48.00 \\
\hline $\mathrm{Ga}$ & 19.00 & 20.00 & 19.00 & 20.00 & 19.00 \\
\hline outcrop & $\begin{array}{l}\text { T0 } \\
\text { andesitic } \\
\text { lava }\end{array}$ & $\begin{array}{l}\text { T1 } \\
\text { andesitic lava }\end{array}$ & $\begin{array}{l}\text { G2-63 } \\
\text { andesitic } \\
\text { porphyry }\end{array}$ & $\begin{array}{l}\text { G3-134 } \\
\text { andesitic dike }\end{array}$ & $\begin{array}{l}\text { G3-157 } \\
\text { andesitic lava }\end{array}$ \\
\hline $\mathrm{Mg} \#$ & 45.71 & 57.51 & 56.51 & 57.66 & 44.46 \\
\hline CA/Thindex & 1.50 & 2.23 & 2.16 & 1.88 & 1.19 \\
\hline$[\mathrm{La} / \mathrm{Yb}]_{\mathrm{N}}$ & 12.78 & 11.18 & 12.08 & 13.77 & 7.42 \\
\hline$[\mathrm{La} / \mathrm{Sm}]_{\mathrm{N}}$ & 4.04 & 3.14 & 4.34 & 2.57 & 2.21 \\
\hline$[\mathrm{La} / \mathrm{Dy}]_{\mathrm{N}}$ & 10.23 & 7.83 & 9.49 & 8.07 & 4.88 \\
\hline
\end{tabular}


Table 1-Appendix (continued)

\begin{tabular}{|c|c|c|c|c|c|}
\hline \multirow[t]{2}{*}{ outcrop } & T0 & $\mathrm{T} 1$ & G2-63 & G3-134 & G3-157 \\
\hline & $\begin{array}{l}\text { andesitic } \\
\text { lava }\end{array}$ & andesitic lava & $\begin{array}{l}\text { andesitic } \\
\text { porphyry }\end{array}$ & andesitic dike & andesitic lava \\
\hline Main rock type & Amp-dacite & Amp-trachydacite & Amp-dacite & Amp-andesite & Cpx-trachydacite \\
\hline Phenocrysts and microphenocrysts & $\mathrm{Pl}+\mathrm{Amp}$ & $\mathrm{Pl}+\mathrm{Amp}+\mathrm{Cpx}+\mathrm{Bt}$ & $\mathrm{Pl}+\mathrm{Amp}+\mathrm{Bt}$ & $\begin{array}{l}\mathrm{Pl}+\text { Amp (Cpx cores in } \\
\text { Amp) }\end{array}$ & $\begin{array}{l}\mathrm{Pl}+\mathrm{Cpx} \text { (Amp } \\
\text { microphenocrysts) }\end{array}$ \\
\hline Accesory minerals & Titanomagne & tite, apatite, titanite & & & \\
\hline$[\mathrm{Ho} / \mathrm{Lu}]_{\mathrm{N}}$ & 1.00 & 0.95 & 0.99 & 1.29 & 1.25 \\
\hline$[\mathrm{Dy} / \mathrm{Yb}]_{\mathrm{N}}$ & 1.25 & 1.43 & 1.27 & 1.71 & 1.52 \\
\hline $\mathrm{La} / \mathrm{Sm}$ & 6.47 & 5.03 & 6.96 & 4.11 & 3.54 \\
\hline $\mathrm{Sm} / \mathrm{Yb}$ & 2.91 & 3.27 & 2.56 & 4.93 & 3.08 \\
\hline $\mathrm{Eu} / \mathrm{Eu}^{*}$ & 0.96 & 0.91 & 1.08 & 0.90 & 0.87 \\
\hline Dy/Dy* & 0.57 & 0.68 & 0.59 & 0.76 & 0.82 \\
\hline Dy/Yb & 1.91 & 2.18 & 1.94 & 2.61 & 2.32 \\
\hline $\mathrm{La} / \mathrm{Ta}$ & 34.50 & 36.20 & 40.00 & 16.89 & 43.67 \\
\hline $\mathrm{Ba} / \mathrm{Nb}$ & 153.20 & 313.25 & 245.50 & 142.86 & 161.67 \\
\hline $\mathrm{La} / \mathrm{Nb}$ & 4.14 & 4.53 & 4.00 & 4.34 & 4.37 \\
\hline $\mathrm{Nb} / \mathrm{Zr}$ & 0.04 & 0.04 & 0.03 & 0.02 & 0.02 \\
\hline $\mathrm{Nb} / \mathrm{Ta}$ & 8.33 & 8.00 & 10.00 & 3.89 & 10.00 \\
\hline $\mathrm{Ce} / \mathrm{Pb}$ & 2.23 & 3.82 & 3.42 & 4.48 & 1.64 \\
\hline $\mathrm{Th} / \mathrm{Nb}$ & 0.76 & 0.63 & 0.48 & 0.57 & 0.73 \\
\hline $\mathrm{Ba} / \mathrm{La}$ & 18.21 & 17.21 & 19.21 & 21.21 & 22.21 \\
\hline Th/La & 0.18 & 0.14 & 0.12 & 0.13 & 0.17 \\
\hline $\mathrm{Ta} / \mathrm{Hf}$ & 0.22 & 0.17 & 0.08 & 0.15 & 0.05 \\
\hline ASI index & 0.91 & 0.94 & 0.97 & 0.79 & 0.74 \\
\hline Liquid-only-Molina et al. (2015) & 992 & 1052 & 1032 & 1041 & 991 \\
\hline Liquid-only-Putirka (2016)-Eqn.3 & 960 & 1002 & 991 & 1008 & 1002 \\
\hline M value (Harrison and Watson, 1983) & 2.33 & 1.83 & 2.37 & 1.89 & 1.89 \\
\hline $\begin{array}{l}\text { Zr-saturation } \mathrm{T}\left({ }^{\circ} \mathrm{C}\right) \text {-Harrison \& Watson } \\
\quad(1983)\end{array}$ & 740 & 644 & 730 & 722 & 725 \\
\hline $\begin{array}{l}\text { Zr-saturation } \mathrm{T}\left({ }^{\circ} \mathrm{C}\right) \text {-Boehnke et al. } \\
\text { (2013) }\end{array}$ & 659 & 569 & 648 & 652 & 655 \\
\hline $\begin{array}{l}\text { Ap-saturation } \mathrm{T}\left({ }^{\circ} \mathrm{C}\right) \text {-Harrison \& } \\
\text { Watson }(1984)\end{array}$ & 910 & 877 & 1026 & 851 & 847 \\
\hline
\end{tabular}




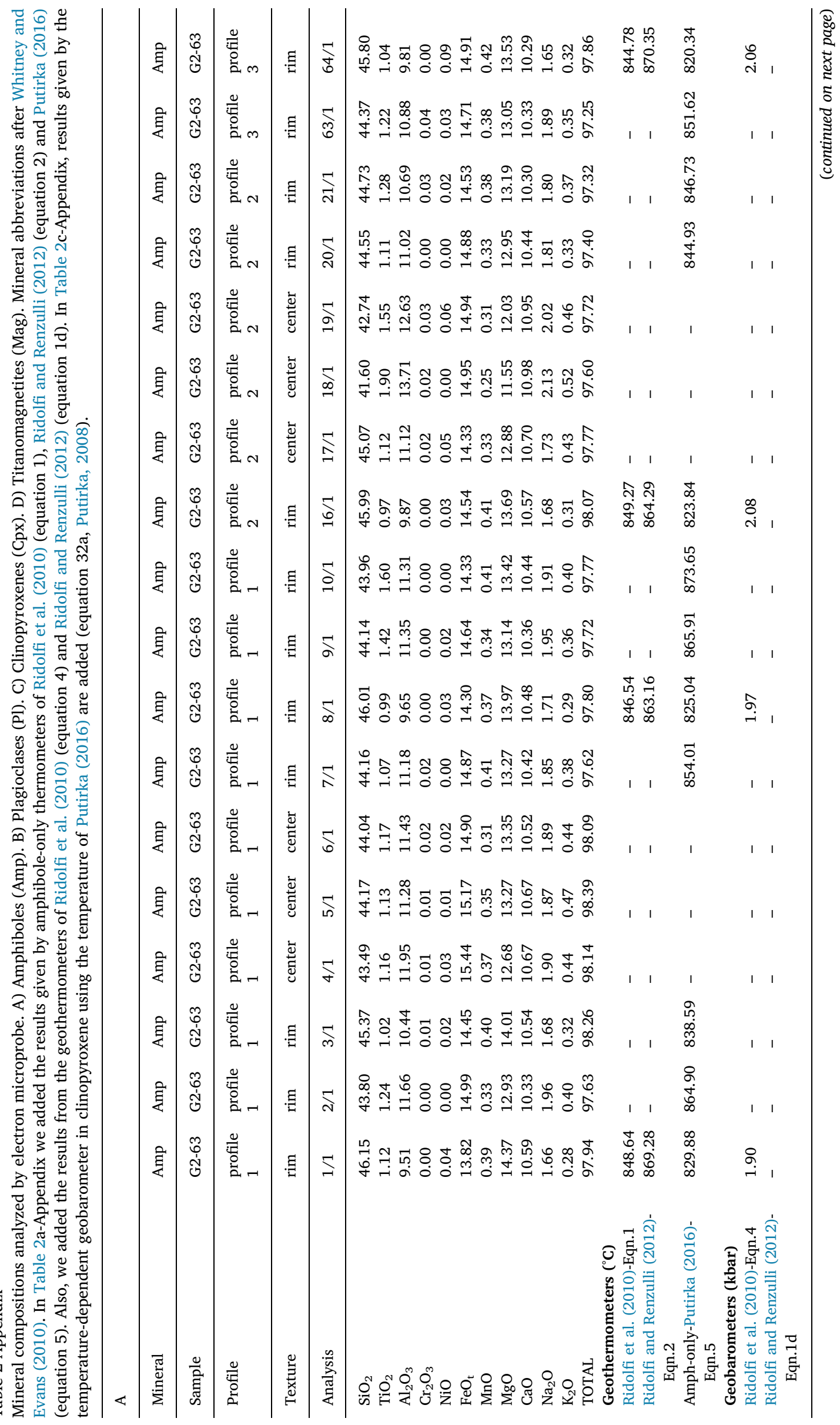




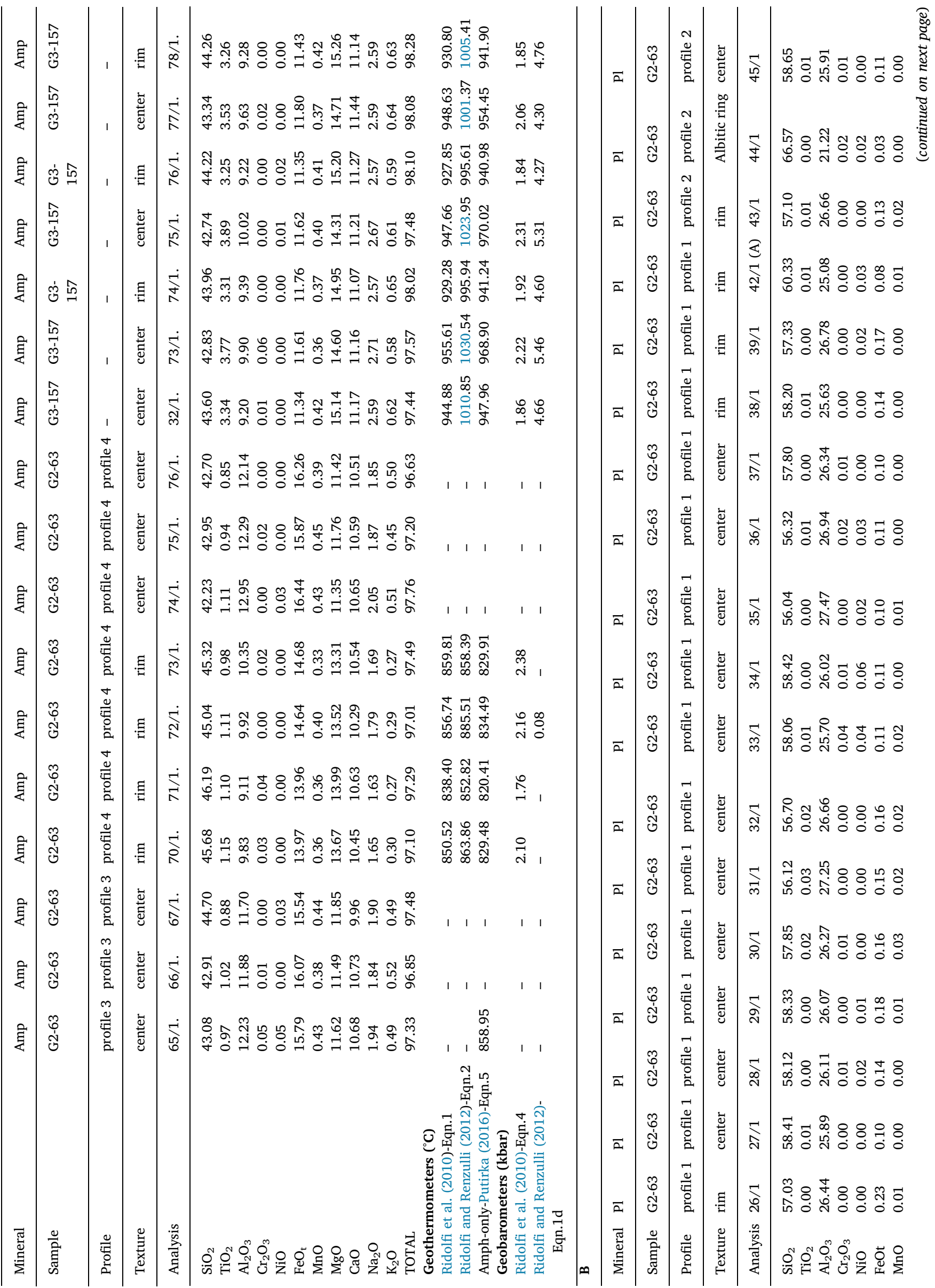




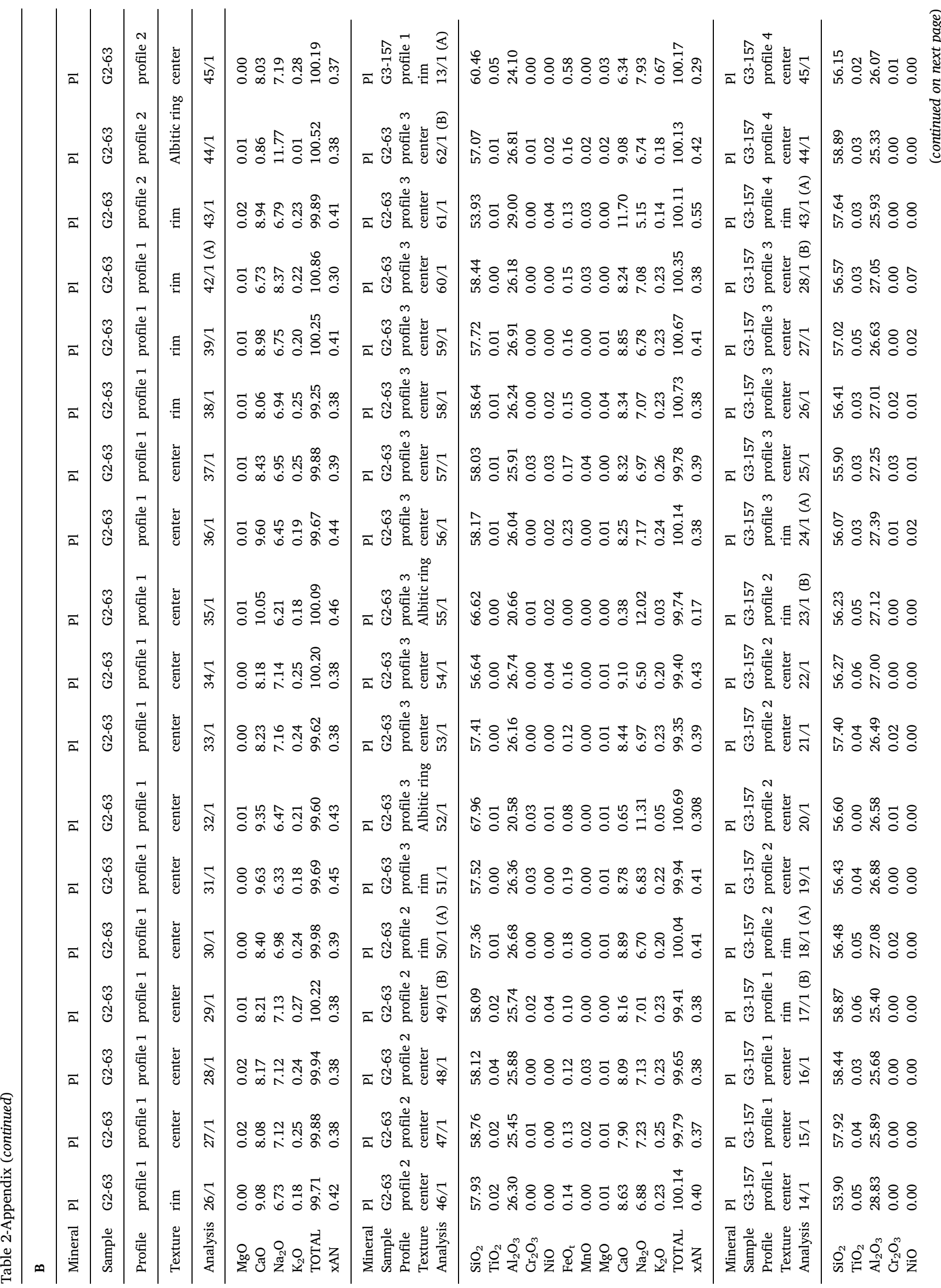




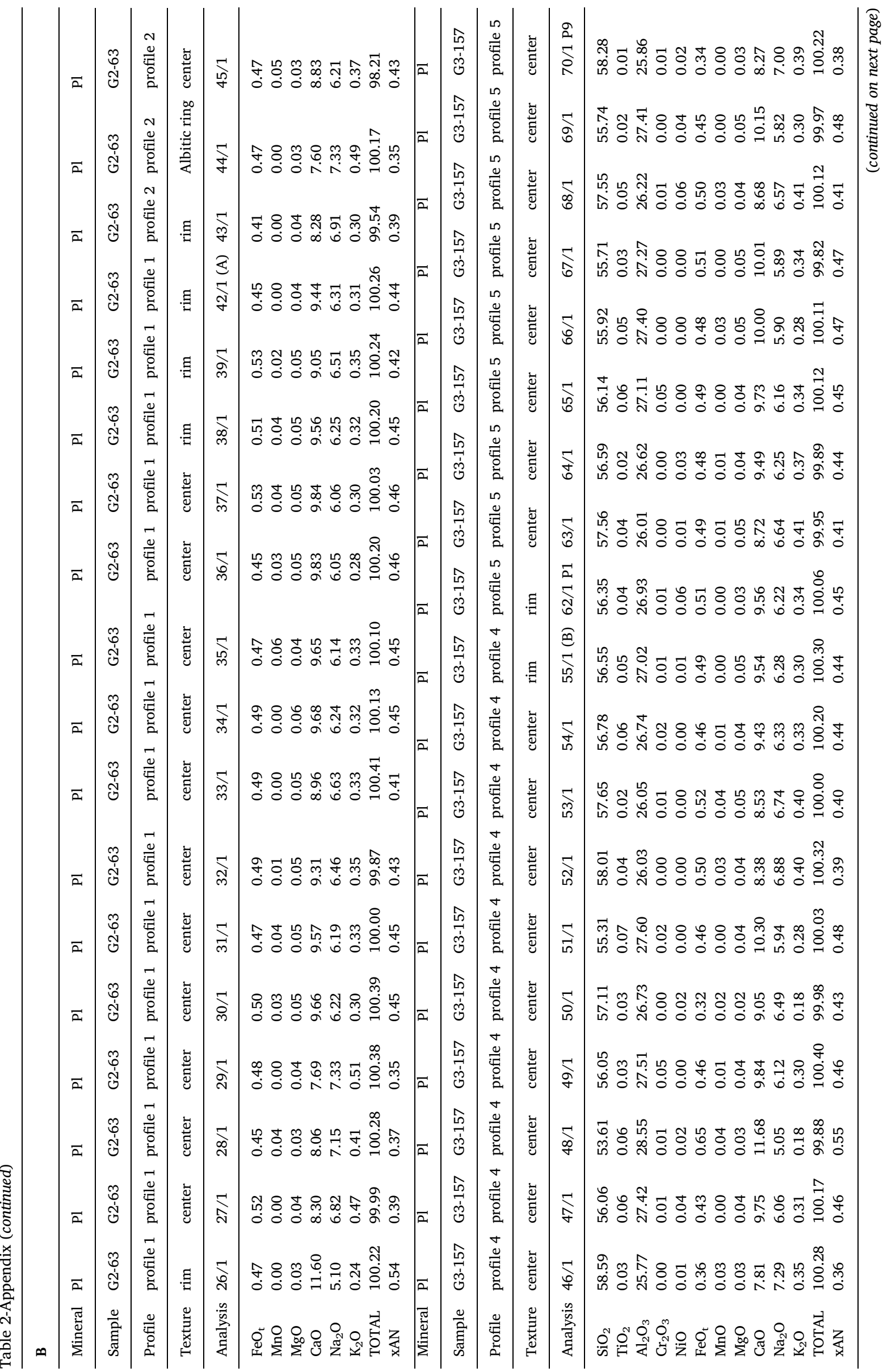




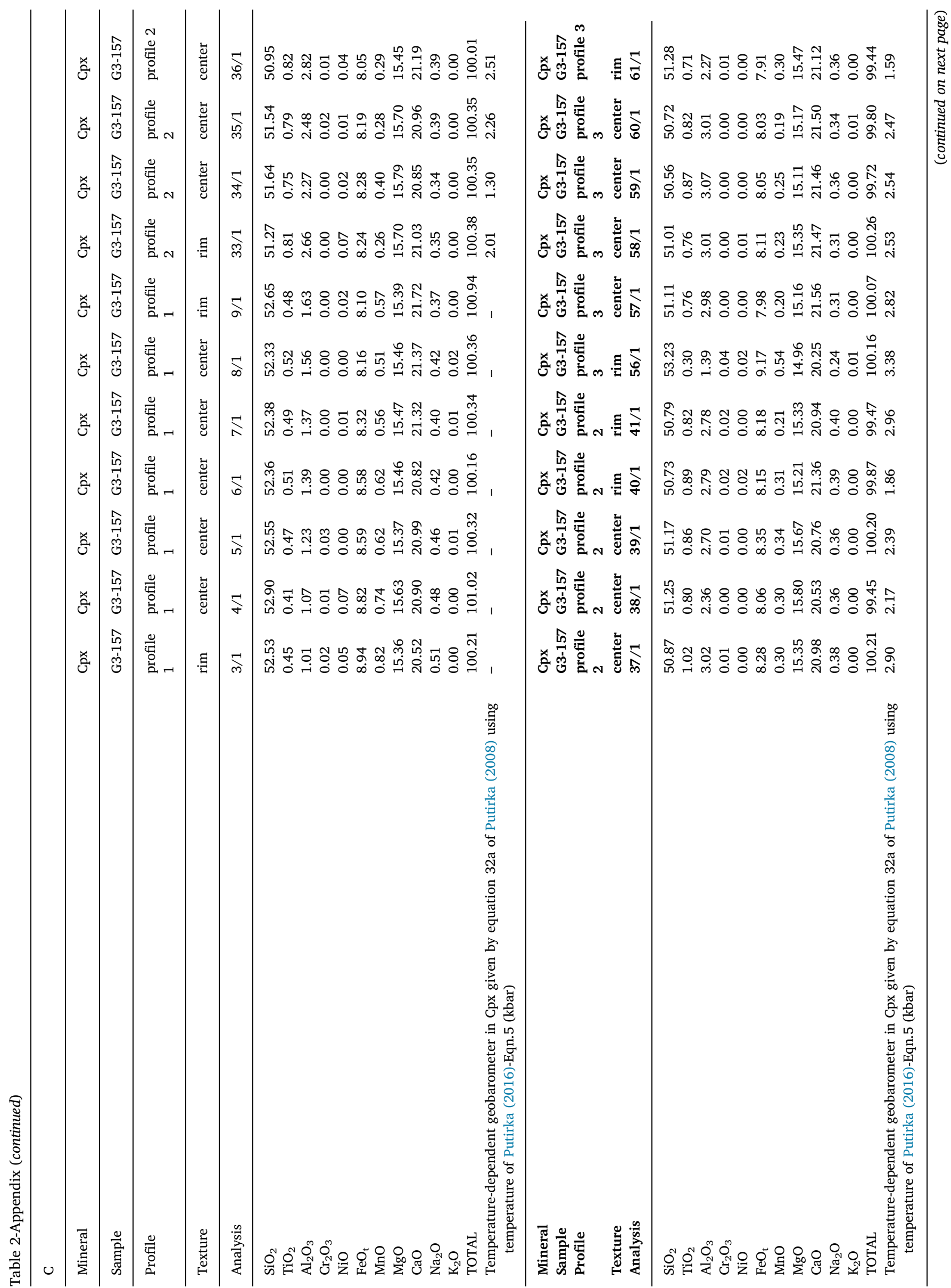



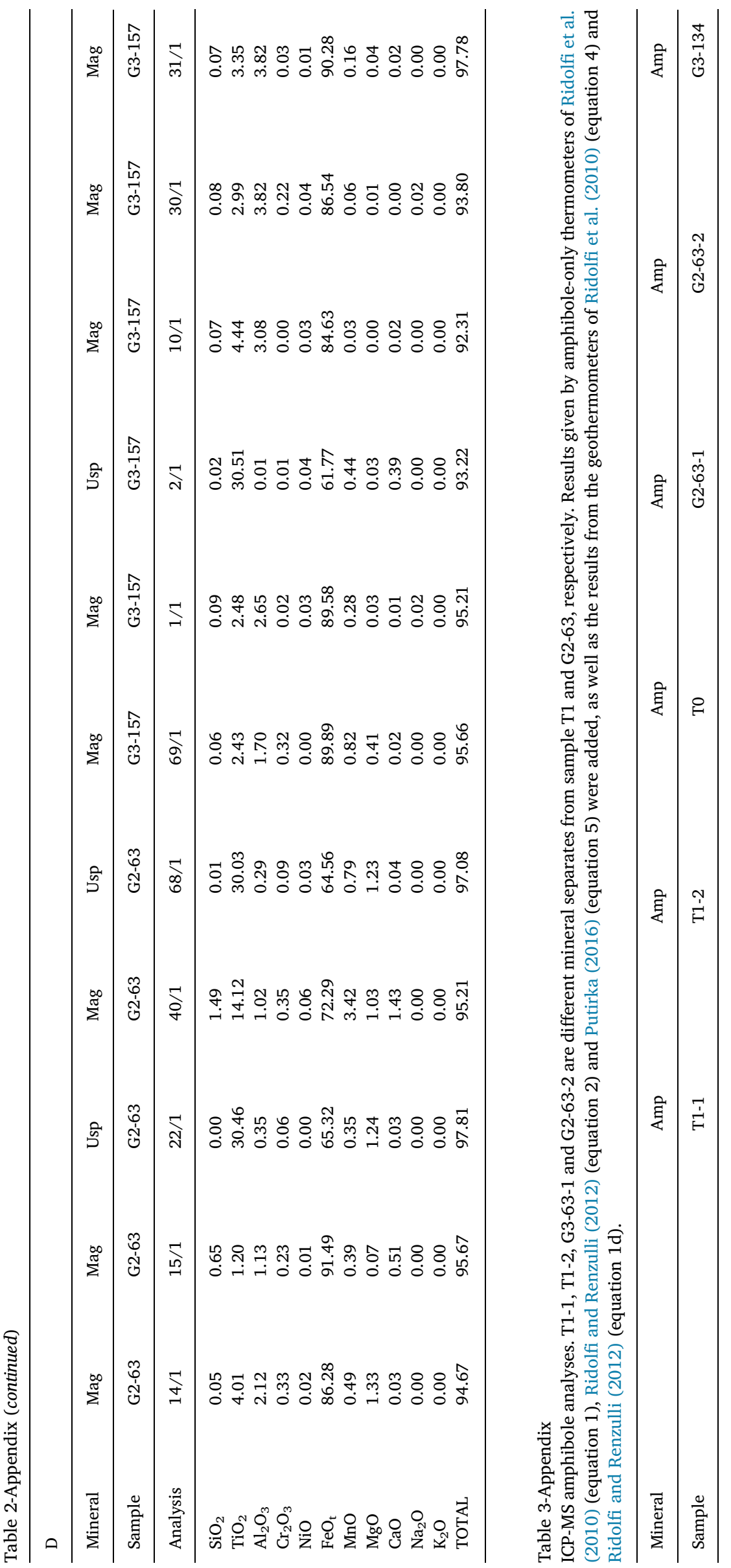

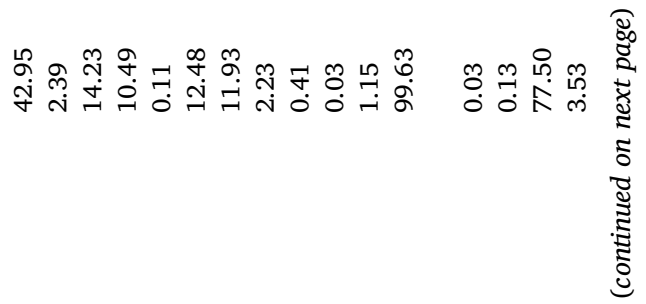

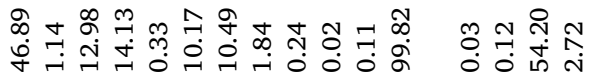

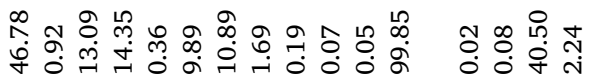

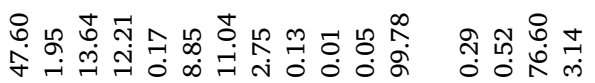

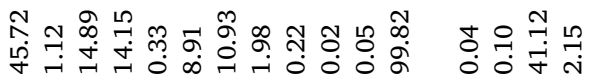

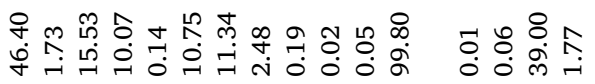

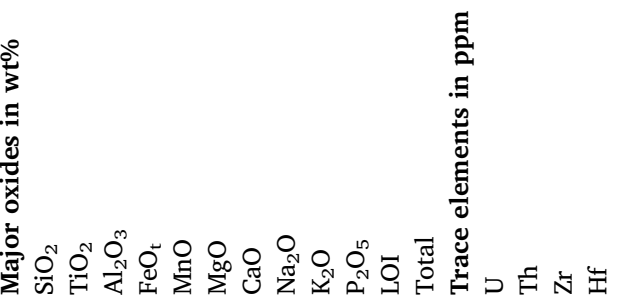




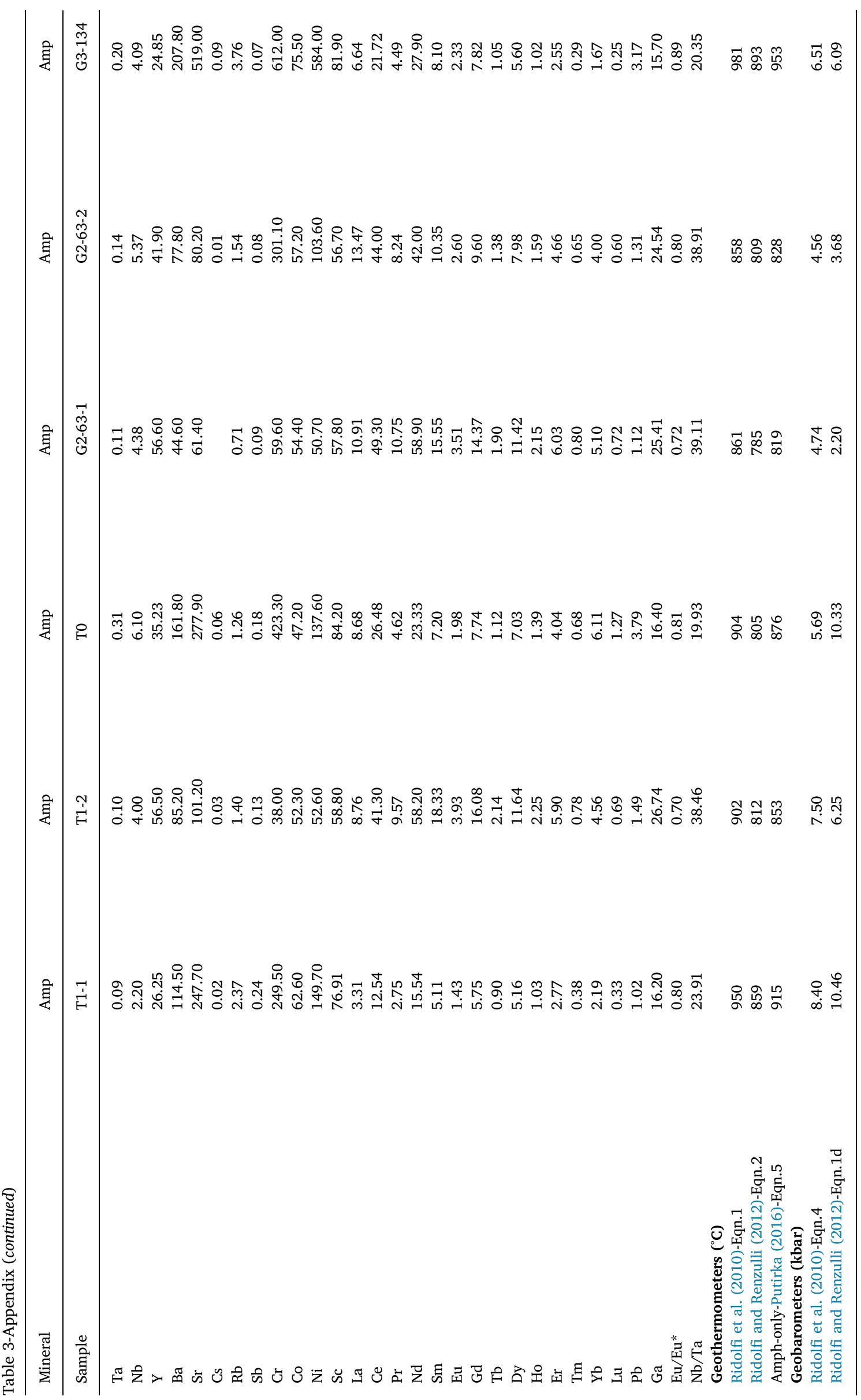




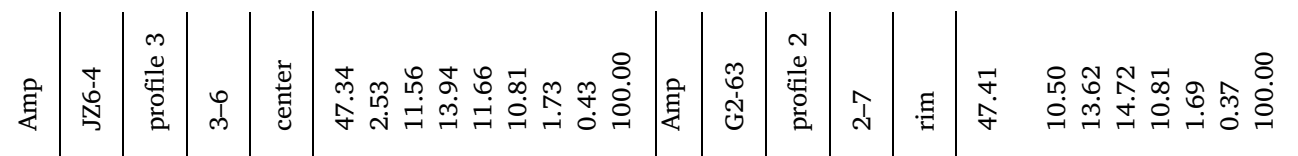

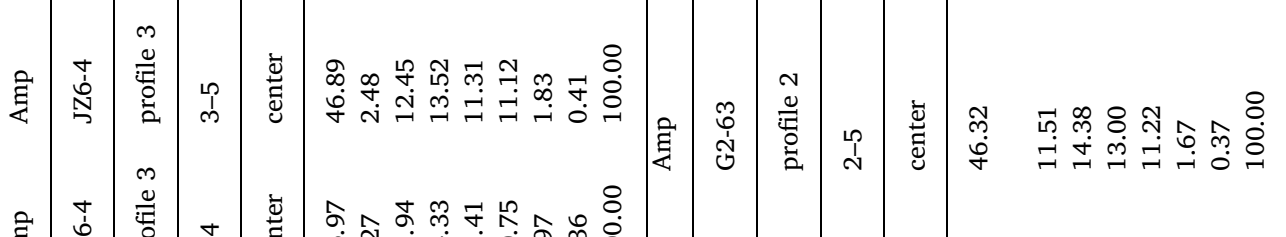

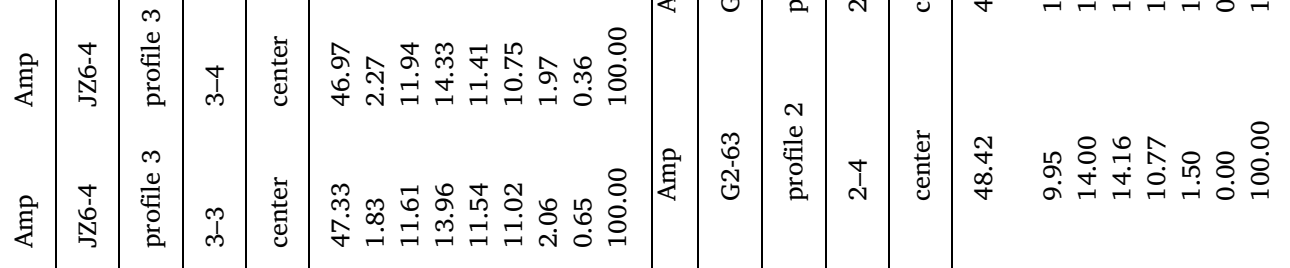

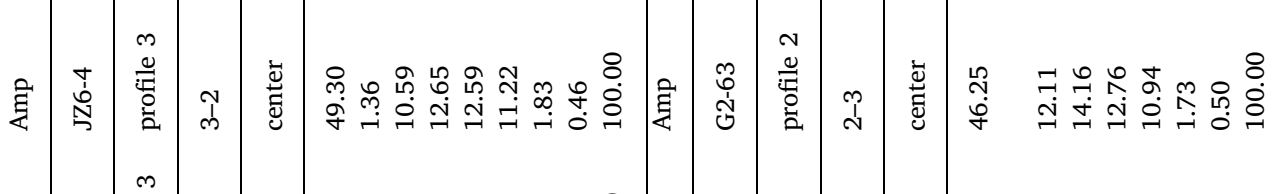

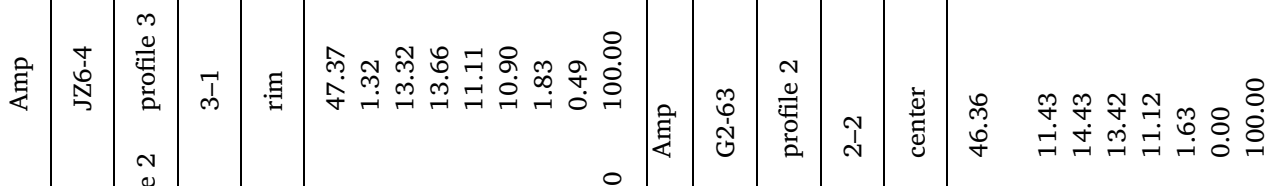

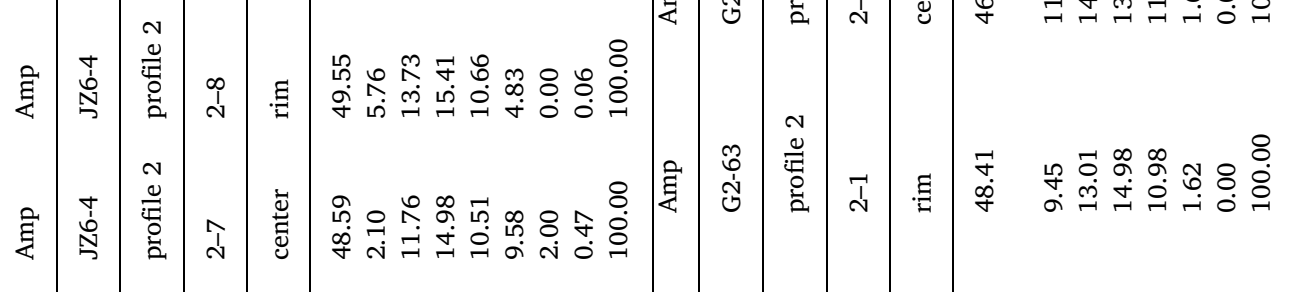

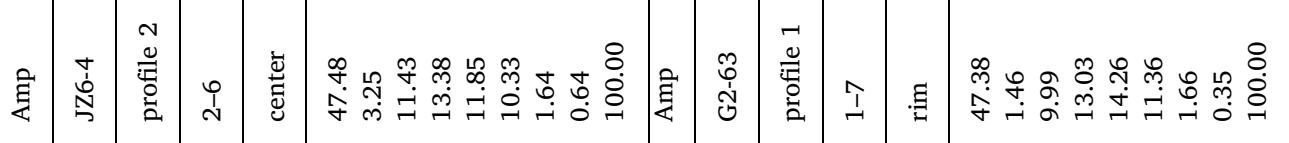

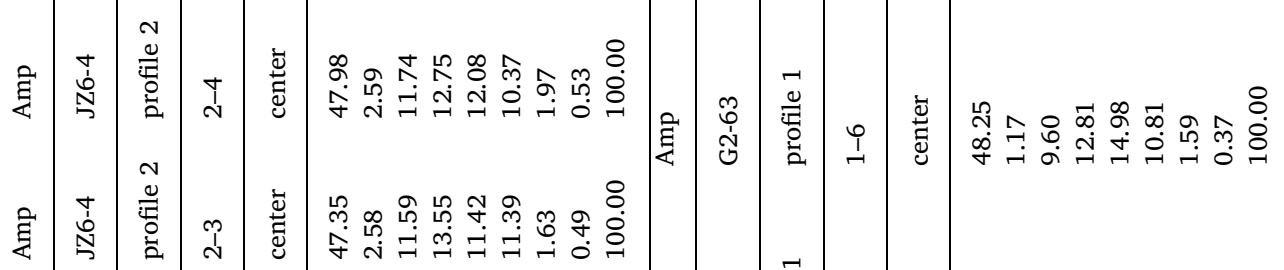

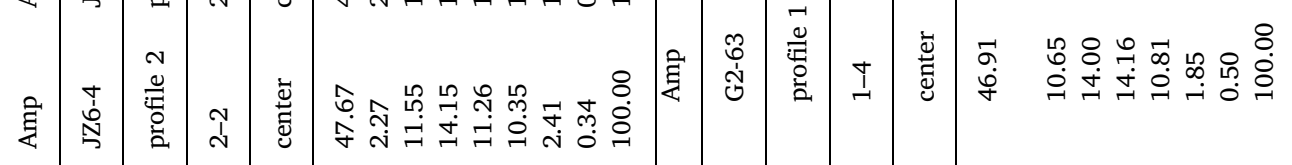

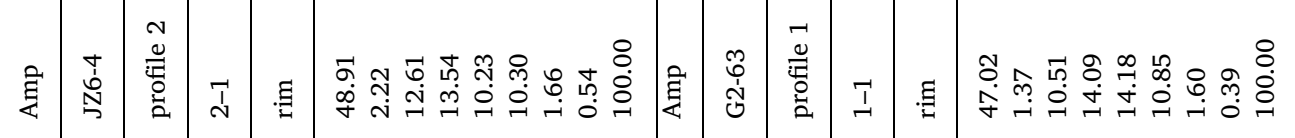

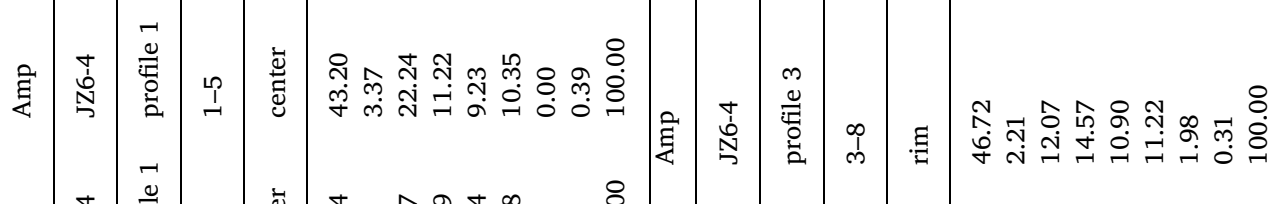

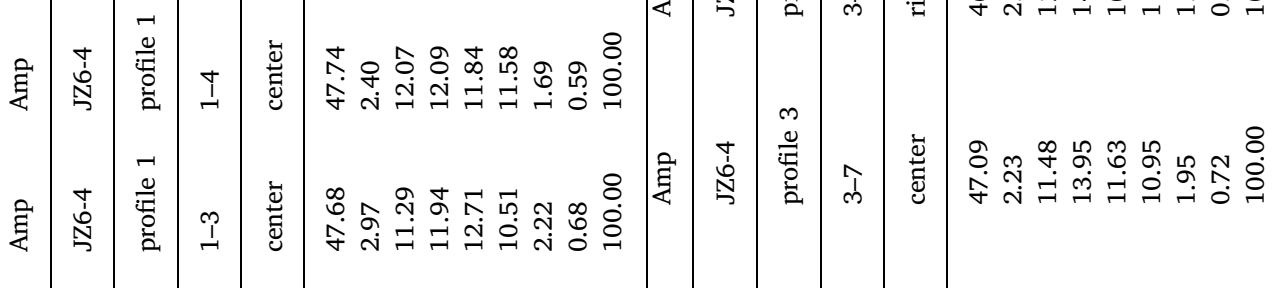

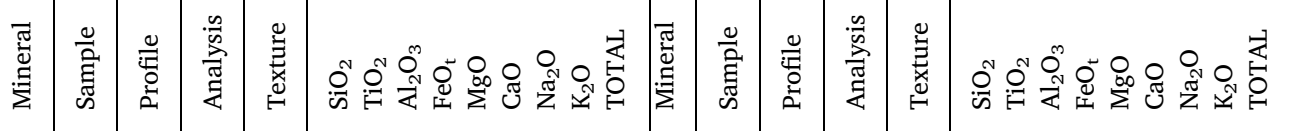




\section{References}

Adam, J., Oberti, R., Camara, F., Green, T.H., 2007. An Electron microprobe, LAM-ICP-MS and single-crystal X-ray structure refinement study of the effects of pressure, melt$\mathrm{H} 2 \mathrm{O}$ concen- tration and fO2 on experimentally produced basaltic amphiboles. Eur. J. Mineral 19 (5), 641-655. https://doi.org/10.1127/0935-1221/2007/0019-1750.

Anderson, J.L., Smith, D.R., 1995. The effects of temperature and $\mathrm{fO}_{2}$ in the Al-in-hornblende barometer. Am. Mineral. 80, 549-559. https://doi.org/10.2138/am-1995-5614.

Arculus, R.J., 2003. Use and abuse of the terms calcalkaline and calcalkalic. J. Petrol. 44, 929-935. https://doi.org/10.1093/petrology/44.5.929.

Bacon, C.R., Druitt, T.H., 1988. Compositional evolution of the zoned calcalkaline magma chamber of mount-Mazama, crater lake, Oregon. Contrib. Mineral. Petrol. 98 (2), 224-256.

Barclay, J., Carmichael, I.S.E., 2004. A hornblende basalt from western Mexico: watersaturated phase relations constrain a pressure-temperature window of eruptibility. J. Petrol. 45, 485-506. https://doi.org/10.1093/petrology/egg091.

Bea, F., 1996. Residence of REE, Y, Th and U in granites and grustal protoliths; implications for the chemistry of crustal melts. J. Petrol. 37 (3), 521-552. https://doi. org/10.1093/petrology/37.3.521.

Bea, F., Montero, P., Ortega, M., 2006. A LA-ICP-MS evaluation of Zr reservoirs in common crustal rocks: implications for $\mathrm{Zr}$ and $\mathrm{Hf}$ geochemistry, and zircon-forming processes. Can. Mineral. 44, 693-714.

Behrens, H., Gaillard, F., 2006. Geochemical aspects of melts. Volatiles and Redox Behavior: Elements 2, 275-290. https://doi.org/10.2113/gselements.2.5.275.

Benedini, L., Gregori, D., 2013. Significance of the early jurassic Garamilla Formation in the western nordpatagonian Massif. J. S. Am. Earth Sci. 45, 259-277. https://doi. org/10.1016/j.jsames.2013.03.016.

Bilmes, A., D’Elia, L., Franzese, J.R., Veiga, G,D,, Hernández, M., 2013. Miocene block uplift and basin formation in the Patagonian foreland: The Gastre Basin, Argentina Tectonophysics 601, 98-111. https://doi.org/10.1016/j.tecto.2013.05.001.

Blundy, J., Cashman, K., 2008. Petrologic reconstruction of magmatic system variables and processes. Rev. Mineral. Geochem. 69 (1), 179-239. http://sci-hub.tw/https:// doi.org/10.2138/rmg.2008.69.6.

Blundy, J., Cashman, K., Humphreys, M., 2006. Magma heating by decompression-driven crystallization beneath andesite volcanoes. Nature 443, 76-80. https://doi.org/10. 1038/nature05100.

Boehnke, P., Watson, E.B., Trail, D., Harrison, T.M., Schmitt, A.K., 2013. Zircon saturation re-revisited. Chem. Geol. 351https://doi.org/10.1016/j.chemgeo.2013.05.028. 324, 334.

Bouhier, V.E., Franchini, M.B., Caffe, P.J., Maydagán, L., Rapela, C.W., Paolini, M., 2017. Petrogenesis of volcanic rocks that host the world-class Ag-Pb navidad district, North Patagonian Massif: comparison with the jurassic Chon Aike volcanic province of Patagonia, Argentina. J. Volcanol. Geoth. Res. 338, 101-120. https://doi.org/10. 1016/j.jvolgeores.2017.03.016.

Buddington, A.F., Lindsley, D.H., 1964. Iron-titanium oxide minerals and synthetic equivalents. J. Petrol. 5 (2), 310-357. https://doi.org/10.1093/petrology/5.2.310.

Cashman, K.V., Sparks, R.S.J., Blundy, J.D., 2017. Vertically extensive and unstable magmatic systems: a unified view of igneous processes. Science 355 (6331). https:// doi.org/10.1126/science.aag3055. eaag3055.

Cortiñas, J.S., 1996. La cuenca de Somuncurá-Cañadón Asfalto: sus límites, ciclos evolutivos del relleno sedimentario y posibilidades exploratorias. In: XIII Congreso Geológico Argentino and III Congreso de Exploración de Hidrocarburos, Buenos Aires, Argentina, pp. 147-163.

Cúneo, R., Ramezani, J., Scasso, R., Pol, D., Escapa, I., Zavattieri, A.M., Bowring, S.A., 2013. High-precision U-Pb geochronology and a new chronostratigraphy for the Cañadón Asfalto Basin, Chubut, central Patagonia: implications for terrestrial faunal and floral evolution in Jurassic. Gondwana Res. 24, 1267-1275. https://doi.org/10. 1016/j.gr.2013.01.010.

Dale, J., Powell, R., White, R.W., Elmer, F.L., Holland, T.J.B., 2005. A thermodynamic model for Ca-Na clinoamphiboles in Na2O-CaO-FeO-MgO-Al2O3-SiO2-H2O-O for petrological calculations. J. Metamorph. Geol. 23, 771-791. https://doi.org/10. 1111/j.1525-1314.2005.00609.x.

Davidson, J., Turner, S., Plank, T., 2013. Dy/Dy*: variations arising from mantle sources and petrogenetic processes. J. Petrol. 54, 525-537. https://doi.org/10.1093/ petrology/egs076.

Dejonghe, L., Darras, B., Hughes, G., Muchez, P., Scoates, J., Weis, D., 2002. Isotopic and fluid-inclusion constraints on the formation of polymetallic vein deposits in the central Argentinian Patagonia. Miner. Deposita 37 (2), 158-172. https://doi.org/10. 1007/s00126-001-0225-8.

Demény, A., Harangi, S., Vennemann, T.W., Casillas, R., Horváth, P., Milton, A.J., Mason, P.R.D., Ulianov, A., 2012. Amphiboles as indicators of mantle source contamination: combined evaluation of stable $\mathrm{H}$ and $\mathrm{O}$ isotope compositions and trace element ratios. Lithos 152, 141-156. https://doi.org/10.1016/j.lithos.2012.07.001.

Echaurren, A., Folguera, A., Gianni, G., Orts, D., Tassara, A., Encinas, A., Giménez, M. Valencia, V., 2016. Tectonic evolution of the North Patagonian Andes $\left(41^{\circ}-44^{\circ} \mathrm{S}\right)$ through recognition of syntectonic strata. Tectonophysics 677, 99-114. https://doi org/10.1016/j.tecto.2016.04.009.

Echaurren, A., Oliveros, V., Folguera, A., Ibarra, F., Creixell, C., Lucassen, F., 2017. Early Andean tectonomagmatic stages in north Patagonia: insights from field and geochemical data. J. Geol. Soc. 174 (3), 405-421. https://doi.org/10.1144/jgs2016-087.

Féraud, G., Alric, V., Fornari, M., Bertrand, H., Haller, M., 1999. 40Ar -39Ar dating or the Jurassic volcanic province of Patagonia: migrating magmatism related to Gondwana break-up and subduction. Earth Planet Sci. Lett. 172, 83-96. https://doi.org/10. 1016/S0012-821X(99)00190-9.
Figari, E.G., Courtade, S.F., 1993. Evolución tectosedimentaria de la Cuenca de Cañadón Asfalto, chubut, Argentina. In: XII Congreso Geológico Argentino and II Congreso de Exploración de Hidrocarburos, pp. 66-77.

Figari, E.G., Scasso, R.A., Cúneo, R.N., Escapa, I., 2015. Estratigrafía y evolución geológica de la Cuenca de Cañadón Asfalto, Provincia del Chubut, Argentina. Lat. Am. J. Sedimentol. Basin Anal. 22 (2), 135-169.

Franzese, J.R., Pankhurst, R.J., Rapela, C.W., Spalletti, L.A., Fanning, C.M., Muravchick, M., 2002. Nuevas evidencias geocronológicas sobre el magmatismo gondwánico en el noroeste del Macizo Norpatagónico. In: Cingolani, C.N., A, C., Linares, E., López de Luchi, M.G., Ostera, H.A., Panarello, H.O. (Eds.), Actas del XV Congreso Geológico Argentino. El Calafate/Santa Cruz, Argentina, pp. 144-148.

Gill, J.B., 1981. Orogenic Andesite and Plate Tectonics. Springer Verlag, New York.

Gordon, A., Ort, M.H., 1993. Edad y correlación del plutonismo subcordillerano de las provincias de Río Negro y Chubut $\left(41^{\circ}-42^{\circ} 30^{\prime}\right.$ L.S.). In: XII Congreso Geológico Argentino and II Congreso de Exploración de Hidrocarburos, Actas, vol. 4. pp $120-127$.

Grove, T.L., Elkins-Tanton, L.T., Parman, S.W., Chatterjee, N., Müntener, O., Gaetani, G.A., 2003. Fractional crystallization and mantle-melting controls on calc-alkaline differentiation trends. Contrib. Mineral. Petrol. 145, 515-533. https://doi.org/10. 1007/s00410-003-0448-z.

Gust, D.A., Biddle, K.T., Phelps, D.W., Uliana, M.A., 1985. Associated middle to late jurassic volcanism and extension in southern south America. Tectonophysics 116, 223-253. https://doi.org/10.1016/0040-1951(85)90210-0.

Haggerty, S., 1991. Oxide textures; a mini-atlas. In: Lindsley, D.H. (Ed.), Oxide Minerals: Petrologic and Magnetic Significance. Reviews in Mineralogy and Geochemistry 25. Mineralogist Society of America, Washington, DC, pp. 129-219.

Haller, M.J., Linares, E., Ostera, H., Page, S., 1999. Petrology and geochronology of the sub-cordilleran plutonic belt of Patagonia. In: II South American Symposium on Isotope Geology, Carlos Paz, Argentina, Segemar, Buenos Aires, pp. 210-214.

Hammarstrom, J.M., Zen, E., 1986. Aluminum in hornblende: an empirical igneous geobarometer. Am. Mineral. 71, 1297-1313.

Harrison, T.M., Watson, E.B., 1983. Kinetics of zircon dissolution and zirconium diffusion in granitic melts of variable water content. Contrib. Mineral. Petrol. 84, 66-72.

Harrison, T.M., Watson, E.B., 1984. The behavior of apatite during crustal anatexis: equilibrium and kinetic considerations. Geochem. Cosmochim. Acta 48, 1467-1477.

Hauser, N., Cabaleri, N.G., Gallego, O.F., Monferran, M.D., Silva Nieto, D., Armella, C., Matteini, M., Aparicio González, P.A., Pimentel, M.M., Volkheimer, W., Reimold, W.U., 2017. U-Pb and Lu-Hf zircon geochronology of the Cañadón Asfalto basin, chubut, Argentina: implications for the magmatic evolution in central Patagonia. J. S. Am. Earth Sci. 78, 190-212. https://doi.org/10.1016/j.jsames.2017.05.001.

Holland, T., Blundy, J., 1994. Non-ideal interactions in calcic amphiboles and their bearing on amphibole-plagioclase thermometry. Contrib. Mineral. Petrol. 116, 433-447. https://doi.org/10.1007/BF00310910.

Hollister, L.S., Grissom, G.C., Peters, E.K., Stowell, H.H., Sisson, V.B., 1987. Confirmation of the empirical correlation of $\mathrm{Al}$ in hornblende with pressure of solidification of calcalkaline plutons. Am. Mineral. 72, 231-239.

Hora, J.M., Singer, B.S., Wörner, G., Beard, B.L., Jicha, B.R., Johnson, C.M., 2009. Shallow and deep crustal control on differentiation of calc-alkaline and tholeiitic magma. Earth Planet Sci. Lett. 285, 75-86. https://doi.org/10.1016/j.epsl.2009.05. 042 .

Irvine, T.N., Baragar, W.R.A., 1971. A guide to the chemical classification of the common volcanic rocks. Can. J. Earth Sci. 8, 523-548.

Johnson, M.C., Rutherford, M.J., 1989. Experimental calibration of the aluminum-inhornblende geobarometer with application to Long Valley caldera (California) volcanic rocks. Geology 17 (9), 837-841. https://doi.org/10.1130/0091-7613(1989) $017<0837$.

Kay, S.M., Burns, W.M., Copeland, P., 2006. Upper Cretaceous to Holocene Magmatism and Evidence for Transient Miocene Shallowing of the Andean Subduction Zone under the Northern Neuquén Basin. Geological Society of America, Special Paper, pp. 19-60. https://doi.org/10.1130/2006.2407(02.

Kiss, B., Harangi, S., Ntaflos, T., Mason, P.R.D., Pál-Molnár, E., 2014. Amphibole perspective to unravel pre-eruptive processes and conditions in volcanic plumbing systems beneath intermediate arc volcanoes: a case study from Ciomadul volcano (SE Carpathians). Contrib. Mineral. Petrol. 167, 1-27. https://doi.org/10.1007/s00410014-0986-6.

Krawczynski, M., Grove, T., Behrens, H., 2012. Amphibole stability in primitive arc magmas: effects of temperature, $\mathrm{H} 2 \mathrm{O}$ content, and oxygen fugacity. Contrib. Mineral. Petrol. 164 (2), 317-339. https://doi.org/10.1007/s00410-012-0740-x.

Le Bas, M.J., 1962. The role of aluminium in igneous clinopyroxenes with relation to their parentage. Am. J. Sci. 260, 267-288.

Leake, B.E., Wooley, A.R., Arps, C.E.S., Birch, W.D., Gilbert, M.C., Grice, J.D., Hawthorne, F.C., 1997. Nomenclature of amphiboles: report of the subcommittee on amphiboles of the International Mineralogical Association Commission on new minerals and mineral names. Can. Mineral. 35, 1571-1606. https://doi.org/10.1180/minmag. 1997.061.405.13.

Leterrier, J., Maury, R.C., Thonon, P., Girard, D., Marchal, M., 1982. Clinopyroxene composition as a method of identification of the magmatic affinities of paleovolcanic series. Earth Planet Sci. Lett. 59, 139-154. https://doi.org/10.1016/0012-821X(82) 90122-4.

López de Luchi, M.G., Cerredo, M.E., 2008. Geochemistry of the mamil choique granitoids at rio chico, río negro, Argentina: late paleozoic crustal melting in the North patagonian Massif. J. S. Am. Earth Sci. 25 (4), 526-546. https://doi.org/10.1016/j. jsames.2007.05.004.

Matsui, Y., Onuma, N., Nagasawa, H., Higuchi, H., Banno, S., 1977. Crystal structure control in trace element partition between crystal and magma. Tectonics 100, 315-324. 
McDonough, W.F., Sun, S.-s., 1995. The composition of the Earth. Chem. Geol. 120, 223-253. https://doi.org/10.1016/0009-2541(94)00140-4.

Miyashiro, A., 1974. Volcanic rock series in island arcs and active continental margins. Am. J. Sci. 274, 321-355. https://doi.org/10.2475/ajs.274.4.321.

Molina, J.F., Scarrow, J.H., Montero, P.G., Bea, F., 2009. High-Ti amphibole as a petrogenetic indicator of magma chemistry: evidence for mildly alkalic-hybrid melts during evolution of Variscan basic-ultrabasic magmatism of Central Iberia. Contrib. Mineral. Petrol. 158, 69-98. https://doi.org/10.1007/s00410-008-0371-4.

Molina, J.F., Montero, P., Bea, F., Scarrow, J.H., 2012. Anomalous xenocryst dispersion during tonalite-granodiorite crystalmush hybridization in the mid crust: mineralogical and geochemical evidence from Variscan appinites (Ávila Batholith, Central Iberia). Lithos 153, 224-242.

Molina, J.F., Moreno, J.A., Castro, A., Rodríguez, C., Fershtater, G.B., 2015. Calcic amphibole thermobarometry in metamorphic and igneous rocks: new calibrations based on plagioclase/amphibole $\mathrm{Al}-\mathrm{Si}$ partitioning and amphibole/liquid $\mathrm{Mg}$ partitioning. Lithos 232, 286-305. https://doi.org/10.1016/j.lithos.2015.06.027.

Moreno, J.A., Molina, J.F., Montero, P., Anbar, M.A., Scarrow, J.H., Cambeses, A., Bea, F., 2014. Unraveling sources of A-type magmas in juvenile continental crust: constraints from compositionally diverse Ediacaran post-collisional granitoids in the Katerina Ring Complex, southern Sinai, Egypt. Lithos 192-195, 56-85. https://doi.org/10. 1016/j.lithos.2014.01.010.

Moreno, J.A., Molina, J.F., Bea, F., Anbar, M.A., Montero, P., 2016. Th-REE- and Nb-Taaccessory minerals in post-collisional Ediacaran felsic rocks from the Katerina Ring Complex (S. Sinai, Egypt): an assessment for the fractionation of $\mathrm{Y} / \mathrm{Nb}, \mathrm{Th} / \mathrm{Nb}, \mathrm{La} / \mathrm{Nb}$ and $\mathrm{Ce} / \mathrm{Pb}$ in highly evolved A-type granites. Lithos 258-259, 173-196. https://doi. org/10.1016/j.lithos.2016.04.020.

Morimoto, N., 1988. Nomenclature of pyroxenes. Mineral. Petrol. 39 (1), 55-76. https:// doi.org/10.1007/BF01226262.

Munker, C., Wörner, G., Yogodzinski, G., Churikova, T., 2004. Behaviour of high field strength elements in subduction zones: constraints from Kamchatka-Aleutian arc lavas. Earth Planet Sci. Lett. 224, 275-293. https://doi.org/10.1016/j.epsl.2004.05. 030 .

Nagasawa, H., Schnetzler, C.C., 1971. Partitioning of rare Earth, alkali, and alkaline Earth elements between phenocrysts and acidic igneous magmas. Geochem. Cosmochim. Acta 35, 953-968. https://doi.org/10.1016/0016-7037(71)90008-1.

Nisbet, E.G., Pearce, J.A., 1977. Clinopyroxene composition in mafic lavas from different tectonic settings. Contrib. Mineral. Petrol. 63, 149-160. https://doi.org/10.1007/ BF00398776.

Nullo, F.E., 1978. Descripción geológica de la Hoja 41d, lipetrén, provincia de Río negro (1:200000). In: pp. 1-88, Secretaría del Estado de Minería, Ministerio de Economía, República Argentina, Boletín N 158.

Nullo, F., Proserpio, C., 1975. La Formación Taquetrén en Cañadón del Zaino (Chubut) y sus relaciones estratigráficas en el ámbito de la Patagonia, de acuerdo a la flora, República Argentina. Rev. Asoc. Geol. Argent. 30, 133-150.

O'Neill, H.S., Pownceby, M.I., 1993. Thermodynamic data from redox reactions at high temperatures. I. An experimental and theoretical assessment of the electrochemical method using stabilized zirconia electrolytes, with revised values for the $\mathrm{Fe}$ - $\mathrm{FeO}$ ", Co-CoO, Ni-NiO and Cu-Cu2O oxygen buffer. Contrib. Mineral. Petrol. 14, 296-314. https://doi.org/10.1007/BF01046533.

Page, S., 1984. Los gabros bandeados de la Sierra de Tepuel: cuerpos del sector sudeste. In: Actas $9^{\circ}$ Congreso Geológico Argentino, pp. 584-599 (Bariloche).

Page, R., Page, S., 1993. Petrología y significado tectónico del Jurásico volcánico de Chubut central. Rev. Asoc. Geol. Argent. 1, 174-176.

Page, S., Page, R., 1999. Las diabasas y gabros del Jurásico de la Precordillera del Chubut. In: In: Caminos, R. (Ed.), Geologia Argentina. Subsecretaria de Mineria de la Nación, Servicio Geológico Minero Argentina, vol. 29. Instituto de Geología y Recursos Minerales, pp. 489-495.

Pankhurst, R.J., Rapela, C.W., 1995. Production of Jurassic rhyolite by anatexis of the lower crust of Patagonia. Earth Planet Sci. Lett. 134, 23-26. https://doi.org/10. 1016/0012-821X(95)00103-J.

Pankhurst, R.J., Sruoga, P., Rapela, C., 1993. Estudio geocronológico Rb/Sr de los Complejos Chon Aike y El Quemado a los $47^{\circ} 30^{\prime}$ LS. XII. Congreso Geológico Argentino, Mendoza, pp. 171-178.

Pankhurst, R.J., Leat, P.T., Sruoga, P., Rapela, C.W., Márquez, M., Storey, B.C., Riley, T.R., 1998. The Chon Aike province of Patagonia and related rocks in West Antarctica: a silicic large igneous province. J. Volcanol. Geoth. Res. 81, 113-136. https://doi.org/10.1016/S0377-0273(97)00070-X.

Pankhurst, R.J., Riley, T.R., Fanning, C.M., Kelley, S.P., 2000. Episodic silicic volcanism in Patagonia and the Antarctic Peninsula: chronology of magmatism associated with the break-up of Gondwana. J. Petrol. 41, 605-625. https://doi.org/10.1093/ petrology/41.5.605.

Pankhurst, R.J., Rapela, C.W., Fanning, C.M., Márquez, M., 2006. Gondwanide continental collision and the origin of Patagonia. Earth Sci. Rev. 76, 235-257. https:// doi.org/10.1016/j.earscirev.2006.02.001.

Peccerillo, A., Taylor, S.R., 1976. Geochemistry of eocene calcalkaline volcanic rocks from the kastamonu area, northern Turkey. Contrib. Mineral. Petrol. 58, 63-81. https://doi.org/10.1007/BF00384745.

Pichavant, M., Martel, C., Bourdier, J.L., Scaillet, B., 2002. Physical conditions, structure, and dynamics of a zoned magma chamber: mount Peleé (Martinique, Lesser Antilles Arc). J. Geophys. Res. 107 (B5). https://doi.org/10.1029/2001JB000315. ECV 1-1ETG 5-16.

Poma, S., 1986. Petrología de las rocas básicas precretácicas de la sierra de Tepuel, provincia del Chubut. Ph.D. thesis. Universidad de Buenos Aires, Buenos Aires, pp. 256.

Proserpio, C.A., 1978. Descripción Geológica de la Hoja 42d, Gastre, Provincia del Chubut (1:200000). In: Secretaría del Estado de Minería, Ministerio de Economía, Boletín N ${ }^{\circ}$
159, pp. 1-75.

Putirka, K.D., 2008. Thermometers and barometers for volcanic systems. Minerals, inclusions and volcanic processes. Rev. Mineral. Geochem. 69, 61-120. https://doi. org/10.2138/rmg.2008.69.3.

Putirka, K., 2016. Amphibole thermometers and barometers for igneous systems, and some implications for eruption mechanisms of felsic magmas at arc volcanoes. Am. Mineral. 101, 841-858. https://doi.org/10.2138/am-2016-5506.

Ramos, V.A., Cristallini, E., Introcaso, A., 2004. The andean thrust system- latitudinal variations in structural styles and orogenic shortening. Aapg Memoir 82, 30-50.

Rapela, C.W., Pankhurst, R.J., 1992. The granites of northern Patagonia and the Gastre fault system in relation to the break-up of Gondwana. In: Storey, A.T., C, B., Pankhurst, R.J. (Eds.), Magmatism and the Causes of Continental Break-up. Geological Society of London Special Publication, pp. 209-220. https://doi.org/10. 1144/GSL.SP.1992.068.01.13.

Rapela, C.W., Dias, G.F., Franzese, J.R., Alonso, G., Benvenuto, A.R., 1991. El Batolito de la Patagonia central: evidencias de un magmatismo triásico-jurásico asociado a fallas transcurrentes. Rev. Geol. Chile 18 (2), 121-138.

Rapela, C.W., Pankhurst, R.J., Fanning, C.M., Hervé, F., 2005. Pacific subduction coeval with the Karoo mantle plume: the Early Jurasssic Subcordilleran belt of northwestern Patagonia. Geological Society, London, Special Publications 246, 217-239. https:// doi.org/10.1144/GSL.SP.2005.246.01.07.

Reguzzoni, M., Sampietro, D., 2015. GEMMA: an Earth crustal model based on GOCE satellite data. Int. J. Appl. Earth Obs. Geoinf. 35 (PA), 31-43DOI. https://doi.org/10. 1016/j.jag.2014.04.002.

Ridolfi, F., Renzulli, A., 2012. Calcic amphiboles in calc-alkaline and alkaline magmas: thermobarometric and chemometric empirical equations valid up to $1130{ }^{\circ} \mathrm{C}$ and 2.2 GPa. Contrib. Mineral. Petrol. 163 (5), 877-895. https://doi.org/10.1007/s00410011-0704-6.

Ridolfi, F., Puerini, M., Renzulli, A., Menna, M., Toulkeridis, T., 2008. The magmatic feeding system of El Reventador volcano (Sub-Andean zone, Ecuador) constrained by texture, mineralogy and thermobarometry of the 2002 erupted products. J. Volcanol. Geoth. Res. 176, 94-106. https://doi.org/10.1016/j.jvolgeores.2008.03.003.

Ridolfi, F., Renzulli, A., Puerini, M., 2010. Stability and chemical equilibrium of amphibole in calc-alkaline magmas: an overview, new thermobarometric formulations and application to subduction-related volcanoes. Contrib. Mineral. Petrol. 160, 45-66. https://doi.org/10.1007/s00410-009-0465-7.

Riley, T.R., Leat, P., Pankhurst, R.J., Harris, C., 2001. Origins of large volume rhyolitic volcanism in the antarctic Peninsula and Patagonia by crustal melting. J. Petrol. 42 (6), 1043-1065. https://doi.org/10.1093/petrology/42.6.1043.

Rudnick, R.L., Gao, L., 2003. Composition of the continental crust. In: Rudnick, R.L. (Ed.), Treatise on Geochemistry. Elsevier, pp. 1-64.

Rutherford, M.J., Devine, J.D., 2008. Magmatic conditions and processes in the storage zone of the 2004-2006 Mount St. Helens Dacite. In: In: Sherrod, D.R., Scott, W.E., Stauffer, P.H. (Eds.), A Volcano Rekindled: the Renewed Eruption of Mount St. Helens, 2004-2006, vol. 31. pp. 703-725 US Geol Surv Prof Paper 1750.

Sas, M., Debari, S.M., Clynne, M.A., Rusk, B.G., 2017. Using mineral geochemistry to decipher slab, mantle, and crustal input in the generation of high-Mg andesites and basaltic andesites from the northern Cascade Arc. Am. Mineral. 102https://doi.org/ 10.2138/am-2017-5756. 948- LP-965.

Sato, A.M., Basei, M.A.S., Tickyj, H., Llambías, E.J., Varela, R., 2004. Granodiorita El Sótano: plutón jurásico deformado aflorante en el basamento de Las Grutas, Macizo Norpatagónico Atlántico. Rev. Asoc. Geol. Argent. 59, 591-600.

Scarrow, J.H., Molina, J.F., Bea, F., Montero, P., 2009. Within-plate calc-alkaline rocks: insights from alkaline mafic magma-peraluminous crustal melt hybrid appinites of the Central Iberian Variscan continental collision. Lithos 110, 50-64. https://doi.org/ 10.1016/j.lithos.2008.12.007.

Schmidt, M.W., 1992. Amphibole composition in tonalite as a function of pressure: an experimental calibration of the $\mathrm{Al}$-in-hornblende barometer. Contrib. Mineral. Petrol. 110, 304-310. https://doi.org/10.1007/BF00310745.

Schnetzler, C.C., Philpotts, J.A., 1970. Partition coefficients of rare-earth elements between igneous matrix material and rock-forming mineral phenocrysts; II. Geochem. Cosmochim. Acta 34 (3), 331-340. https://doi.org/10.1016/0016-7037(70)90110-9.

Simakin, A., Zakrevskaya, O., Salova, T., 2012. Novel Amphibole Geobarometer with application to mafic xenoliths. Earth Sci. Res. 1 (2), 82-97. https://doi.org/10.5539/ esr.v1n2p82.

Sisson, T.W., 1994. Hornblende-melt trace-element partitioning measured by ion microprobe. Chem. Geol. 117, 331-344. https://doi.org/10.1016/0009-2541(94) 90135-X.

Sisson, T.W., Grove, T.L., 1993. Experimental investigations of the role of H2O in calcalkaline differentiation and subduction zone magmatism. Contrib. Mineral. Petrol. 113, 143-166. https://doi.org/10.1007/BF00283225.

Suárez, M., Márquez, M., 2007. A Toarcian retro-arc basin of Central Patagonia (Chubut), Argentina: middle Jurassic closure, arc migration and tectonic setting. Andean Geol. 34, 63-79.

Sun, S.-s., McDonough, W.F., 1989. Chemical and isotopic systematics of oceanic basalts: implications for mantle composition and processes. Geological Society of London, Special Publication 42, 313-345. https://doi.org/10.1144/GSL.SP.1989.042.01.19.

Tiepolo, M., Oberti, R., Zanetti, A., Vannucci, R., Foley, S.F., 2007. Trace element partitioning between amphibole and silicate melt. In: Hawthorne, F.C., Oberti, R., Della Ventura, G., Mottana, A. (Eds.), Amphiboles. Crystal Chemistry, Occurrence and Health Issues. Reviews in Mineralogy and Geochemistry 67. Mineralogical Society of America and Geochemical Society, Chantilly, pp. 417-452. https://doi.org/10.2138/ rmg.2007.67.11.

Vizán, H., 1998. Paleomagnetism of the lower jurassic lepá and osta arena for- mations, argentine Patagonia. J. S. Am. Earth Sci. 11, 333-350. https://doi.org/10.1016/ S0895-9811(98)00018-2. 
Volkheimer, W., 1964. Estratigrafía de la región extra-andina del Departamento de Cushamen (Chubut), entre los paralelos $42^{\circ}$ y $42^{\circ} 30^{\prime}$ y los meridianos $70^{\circ}$ y $71^{\circ}$. Rev, Asoc. Geol. Argent. 20 (2), 85-107.

Whitney, D.L., Evans, B.W., 2010. Abbreviations for names of rock-forming minerals. Am. Mineral. 95, 185-187. https://doi.org/10.2138/am.2010.3371.

Winchester, J.A., Floyd, P.A., 1977. Geochemical discrimination of different magma series and their differentiation products using inmobile elements. Chem. Geol. 20, 325-343. https://doi.org/10.1016/0009-2541(77)90057-2.

Wörner, G., Harmon, R.S., Davidson, J., Moorbath, S., Turner, D.L., Mcmillan, N., Nye, C., López-Escobar, L., Moreno, H., 1988. The Nevados de Payachata volcanic region (18 ${ }^{\circ} \mathrm{S} / 69^{\circ} \mathrm{W}, \mathrm{N}$. Chile). Bull. Volcanol. 50, 287-303. https://doi.org/10.1007/ BF01073587.

Zaffarana, C.B., Somoza, R., 2012. Palaeomagnetism and 40Ar/39Ar dating from Lower Jurassic rocks in Gastre, central Patagonia: further data to explore tectonomagmatic events associated with the break-up of Gondwana. J. Geol. Soc. 169 (4), 371-379. https://doi.org/10.1144/0016-76492011-089.
Zaffarana, C.B., Somoza, R., López de Luchi, M., 2014. The late triassic central patagonian batholith: magma hybridization, ${ }^{40} \mathrm{Ar} /{ }^{39} \mathrm{Ar}$ ages and thermobarometry. J. S. Am. Earth Sci. 55, 94-122. https://doi.org/10.1016/j.jsames.2014.06.006.

Zaffarana, C.B., Somoza, R., Orts, D.L., Mercader, R., Boltshauser, B., Ruiz González, V., Puigdomenech, C., 2017. Internal structure of the central patagonian batholith at Gastre. Geosphere 13 (6), 1973-1992. https://doi.org/10.1130/GES01493.1.

Zaffarana, C.B., Lagorio, S., Orts, D., Busteros, A., Silva Nieto, D., Giacosa, R., Ruiz González, V., Boltshauser, B., Puigdomenech Negre, C., Somoza, R., Haller, M., 2018. First geochemical and geochronological characterization of Late Cretaceous mesosilicic magmatism in Gastre, Northern Patagonia, and its tectonic relation to other coeval volcanic rocks in the region. Geol. Mag. 1. https://doi.org/10.1017/ S0016756818000432.

Zhang, J., Humphreys, M., Cooper, G.F., Davidson, D.P., Macpherson, C.G., 2017. Magma mush chemistry at subduction zones, revealed by new melt major element inversion from calcic amphiboles. Am. Mineral. 102, 1353-1367. https://doi.org/10.2138/am2017-5928. 